\title{
Review: Development of SARS-CoV-2 immuno-enhanced COVID- 19 vaccines with nano-platform
}

\author{
Nawamin Sa-nguanmoo ${ }^{1,2}$, Katawut Namdee ${ }^{3}$, Mattaka Khongkow ${ }^{3}$, Uracha Ruktanonchai ${ }^{3}$, YongXiang Zhao ${ }^{4}$, and \\ Xing-Jie Liang ${ }^{1,2}(\Delta)$ \\ ${ }^{1}$ CAS Center for Excellence in Nanoscience, CAS Key Laboratory for Biomedical Effects of Nanomaterials and Nanosafety, National Center for \\ Nanoscience and Technology of China, Beijing 100190, China \\ ${ }^{2}$ University of Chinese Academy of Sciences, Beijing 100049, China \\ ${ }^{3}$ National Nanotechnology Center (NANOTEC), National Science and Technology Development Agency, Pathum Thani 12120, Thailand \\ ${ }^{4}$ National Center for International Research of Biotargeting Theranostics, Guangxi Key Laboratory of Biotargeting Theranostics, Collaborative \\ Innovation Center for Targeting Tumour Theranostics and Therapy, Guangxi Medical University, Nanning 530021, China
}

(C) Tsinghua University Press and Springer-Verlag GmbH Germany, part of Springer Nature 2021

Received: 24 June 2021 / Revised: 19 August 2021 / Accepted: 19 August 2021

\begin{abstract}
Vaccination is the most effective way to prevent coronavirus disease 2019 (COVID-19). Vaccine development approaches consist of viral vector vaccines, DNA vaccine, RNA vaccine, live attenuated virus, and recombinant proteins, which elicit a specific immune response. The use of nanoparticles displaying antigen is one of the alternative approaches to conventional vaccines. This is due to the fact that nano-based vaccines are stable, able to target, form images, and offer an opportunity to enhance the immune responses. The diameters of ultrafine nanoparticles are in the range of 1-100 nm. The application of nanotechnology on vaccine design provides precise fabrication of nanomaterials with desirable properties and ability to eliminate undesirable features. To be successful, nanomaterials must be uptaken into the cell, especially into the target and able to modulate cellular functions at the subcellular levels. The advantages of nano-based vaccines are the ability to protect a cargo such as RNA, DNA, protein, or synthesis substance and have enhanced stability in a broad range of $\mathrm{pH}$, ambient temperatures, and humidity for long-term storage. Moreover, nano-based vaccines can be engineered to overcome biological barriers such as nonspecific distribution in order to elicit functions in antigen presenting cells. In this review, we will summarize on the developing COVID-19 vaccine strategies and how the nanotechnology can enhance antigen presentation and strong immunogenicity using advanced technology in nanocarrier to deliver antigens. The discussion about their safe, effective, and affordable vaccines to immunize against COVID-19 will be highlighted.
\end{abstract}

\section{KEYWORDS}

COVID-19, SARS-CoV-2, vaccine, nanotechnology, antigen presenting cells (APCs)

\section{Introduction}

The seventh $\beta$-coronavirus severe acute respiratory syndrome coronavirus 2 (SARS-CoV-2) was firstly reported on Dec. 2019 at Wuhan, China. Previously, aCoV (HCoV-229E and HKU-NL63) and four types of $\beta \mathrm{CoV}$ (HCoV-OC43, HCoV-HKU1, SARS$\mathrm{CoV}$, and MERS-CoV) were discovered. The SARS-CoV-2 causes symptoms in the upper respiratory and gastrointestinal tracts. Phylogenetic analysis has revealed that SARS-CoV-2 has four amino acids (PRRA) insert at the edge of S1 and S2 which add the new functional furin cleavage site and improve the ability of the SARS-CoV-2 for binding to enzyme 2 (ACE2) receptor (Fig. 1). The disease from SARS-CoV-2 was named as "coronavirus disease 2019 (COVID-19)" by the World Health Organization (WHO) on 11 February 2020. SARS-CoV-2 has an ancestor sequence derived from bat-CoV-RaTG13. The virus in the bat contains the amino acids polyacrylic acid (PAA) by recombination of sequences that derived from RmYN02 in Rhinolophus malayanus bat. However, the receptor-binding domain (RBD) of SARS-CoV-2 is similar to beta-CoVs in Malayan pangolins
(Manis javanica). Major challenges in designing effective vaccines with minimal adverse effects are to fully understand the virus and how our body stimulates the immune responses. The candidate COVID-19 vaccines in clinical trial consist of the conventional development approach (inactivated virus, viral-based vaccine) and the modern development using nanotechnology platform (nucleic acid-based, protein-based vaccine). Both approaches elicit an immune response and prevent COVID-19. However, common limitations of the conventional vaccines include being administered mainly through parenteral routes and requiring multiple doses [1], cold-chain maintenance that needs to be kept at +2 to $+8{ }^{\circ} \mathrm{C}$ to ensure vaccine potency [2], potential risk of virusbased vaccine localization in the central nervous system [3], and taking many years for safety and efficacy approval [4]. The accelerating vaccine development and deployment to combat SARS-CoV-2 by using modern strategies such as nanoparticle formulated vaccines and the evaluation are urgently needed [5-7]. Nanotechnology was first applied in medicine to increase the efficacy and bioavailability of drugs in 2005 [8]. It plays an important role on vaccine design and applications. It truly 


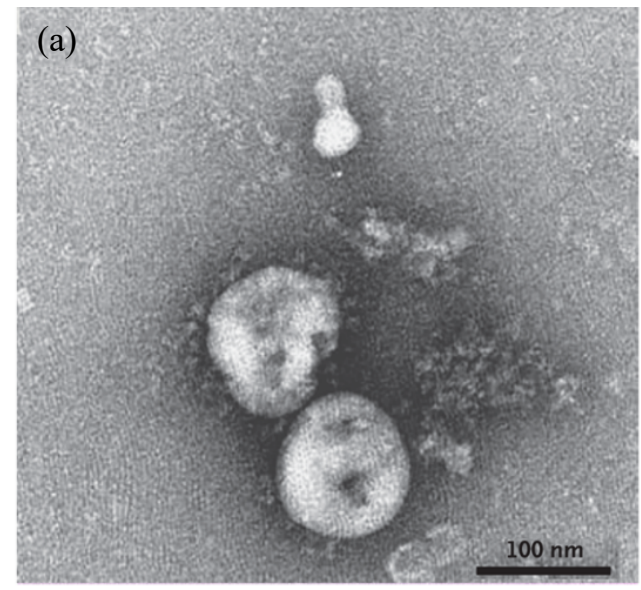

(b)

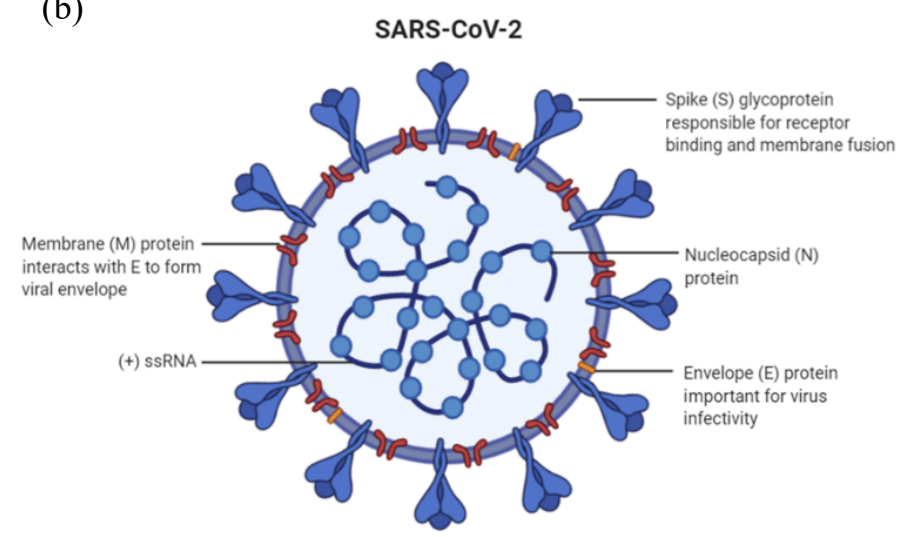

(c)

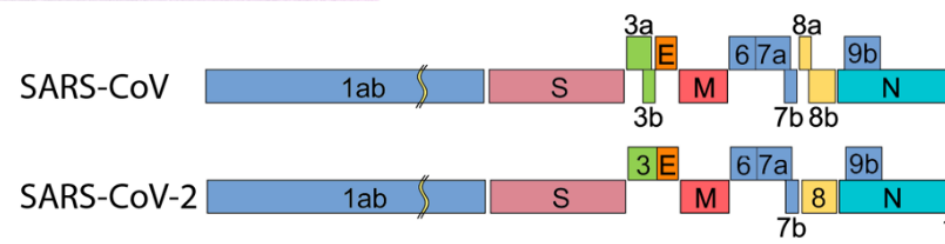

$29,751 \mathrm{bp}$

$29,903 \mathrm{bp}$
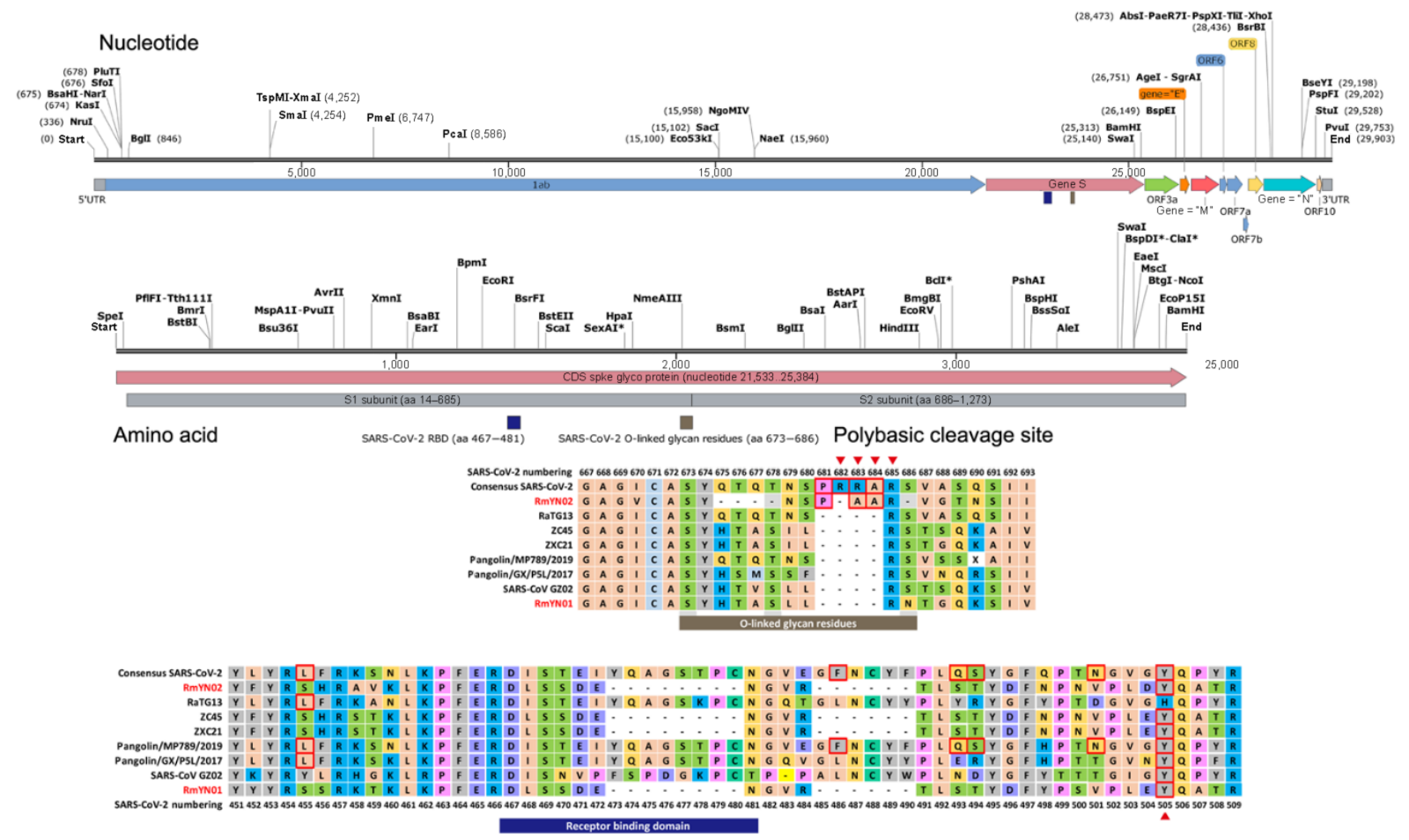

Figure 1 SARS-CoV-2 structure and genome organization. Adapted with permission from Ref. [17], ๑ Chan, J. F., et al. 2020 and Ref. [68], ๑ Published by Elsevier B. V. 2020. An annotated SARS-CoV-2 map (GenBank NC045512.2) created by Snapgene. (a) TEM of SARS-CoV-2 virus particles isolated from a patient. Adapted with permission from Ref. [342], () Massachusetts Medical Society 2020. (b) Illustration of SARS-CoV-2 morphology. (c) Comparative genome organization of coronavirus-related strains. Display genes in the $5^{\prime}-3^{\prime}$ direction.

shortens the usual timeline by using antigens delivery platforms with safer and higher effectiveness than the conventional vaccines, owing to the properties of nanoparticles are able to modify in size, shape, and surface to target the immune cells. In this review, we will begin with an introduction (Section 1), basic biology to understanding of new virus (Section 2), a summary of the vaccines that have been developed (Section 3), how nanoparticles show advantages in the vaccine development (Section 4), and the discussion of COVID-19 vaccines in Phase 3 clinical trial (Section 5).

\section{Biology of SARS-CoV-2}

\subsection{Genomic organization of SARS-CoV-2}

SARS-CoV-2 genome was deposited in the GenBank database
(NC045512.2; MN908947; MN975262.1). SARS-CoV-2 genome consists of 29,903 nucleotides. Phylogenetic analysis cluster SARS$\mathrm{CoV}-2$ in the same group of SARS-CoV and MERS-CoV with similarity score $79 \%$ and $50 \%$, respectively [9]. The order of genes $\left(5^{\prime}\right.$ to $\left.3^{\prime}\right)$ is as follows: open reading frame lab (ORF1ab), spike (S), ORF3a, envelope (E), membrane (M), ORF6, ORF7a, ORF7b, ORF8, nucleocapsid (N), and ORF10 (Fig. 1). The nine-amino acid sequence "LLRKNGNKG" in nsp1 was highly conserved between SARS-CoV (accession No. NC004718) and SAR-CoV-2 [10]. SARS-CoV-2 has completely changed four genes: spike (S), ORF3, ORF8, and ORF10. The crown-liked appearance under microscope comes from Spike (S) proteins, which mediate virus invade into the host [11]. The insertion in O-linked glycan residues (PRRA: amino acids 681-684) at the S1-S2 junction 
provides a new feature of furin cleavage site. Moreover, the receptor binding domain "DISTEIYQAGSTPCN" (amino acids 467-481) derived from pangolin beta-CoVs, allowing a high affinity binding to human angiotensin converting ACE2 receptors [12]. ORF3 of SARS-CoV-2 has mutation in translational process. ORF3b in SARS-CoV-2 has a premature stop codon, a completely novel short protein which is a more potent inhibitor of human IFN-1 and the length of its C-terminus affects the anti-IFN activity [13]. The clinical symptoms of severe COVID-19 patients were reported as the impaired Type I interferons (IFN-I) activity [14]. Type I interferons are soluble immune mediators secreted from viral infected cells and play three major roles. First, they limit the spread of infectious viruses. Second, they modulate innate immune response by promoting natural killer (NK) cell functions, antigen presenting cell (APC), pro-inflammatory, and cytokine production. Third, they activate the adaptive immune responses and immunological memory $[15,16]$. Furthermore, the novel ORF8 of SARS-CoV-2 was predicted to form an alpha helix with six strands of beta-sheet(s) proteins which the annotation of this motif is unknown [17]. Previously annotated ORF8 of SAR-CoV has virus replicative fitness function in the human-to-human transmission [18]. Clinical data of COVID-19 patients infected with 382-nucleotide deletion in ORF8 had mild symptom, more effective T-cell responses, and lower concentrations of proinflammatory cytokines. It was hypothesized that the major deletion ORF8 in SARS-CoV-2 may lead to weakened of COVID19 symptoms $[19,20]$. ORF10 is the new ORF which is not found in SARS-CoV. ORF10 is a unique short protein or peptide of 38 residues length, which does not have any similar proteins in the National Center for Biotechnology Information (NCBI) database. No annotated function was found [21] and could not be detected by liquid chromatography-mass spectrometry/mass spectrometry (LC-MS/MS) in proteomics analysis [22, 23].

\subsection{The SARS-CoV-2 life cycle}

\subsubsection{Infectious cycle in the host}

SARS-CoV-2 infectious cycle begins once its Spike binds to the ACE2 receptors which are found in various tissues such as lungs, adipose tissue, and small intestine [24]. After receptor binding, the host serine protease TMPRSS2 cleaved viral S and the viral envelope fused to cell membrane along the endosomal pathway [25] (Fig. 2). The viral RNA was released into the host cell and translated into polyproteins, then viral polyproteins were cleaved into small products [26]. The viral replication proteins (16 nonstructural proteins) were encoded from ORF1. Sub genomic messenger RNAs (mRNAs) were initiated at the $3^{\prime}$ end of the viral genome and terminated at the transcriptional regulatory sequences (TRS). The nascent transcript transferred to the complementary leader TRS through the base-pairing interaction. The transcription started from the $5^{\prime}$ end of the viral genome. RNA replication occurred on double membrane vesicles (DMVs) [27]. The replicated viral genomic RNA was assembling on ER-Golgi intermediate compartment (ERGIC) and formed mature virion inside Golgi vesicle. Then, they were released out through exocytosis pathway $[28,29]$.

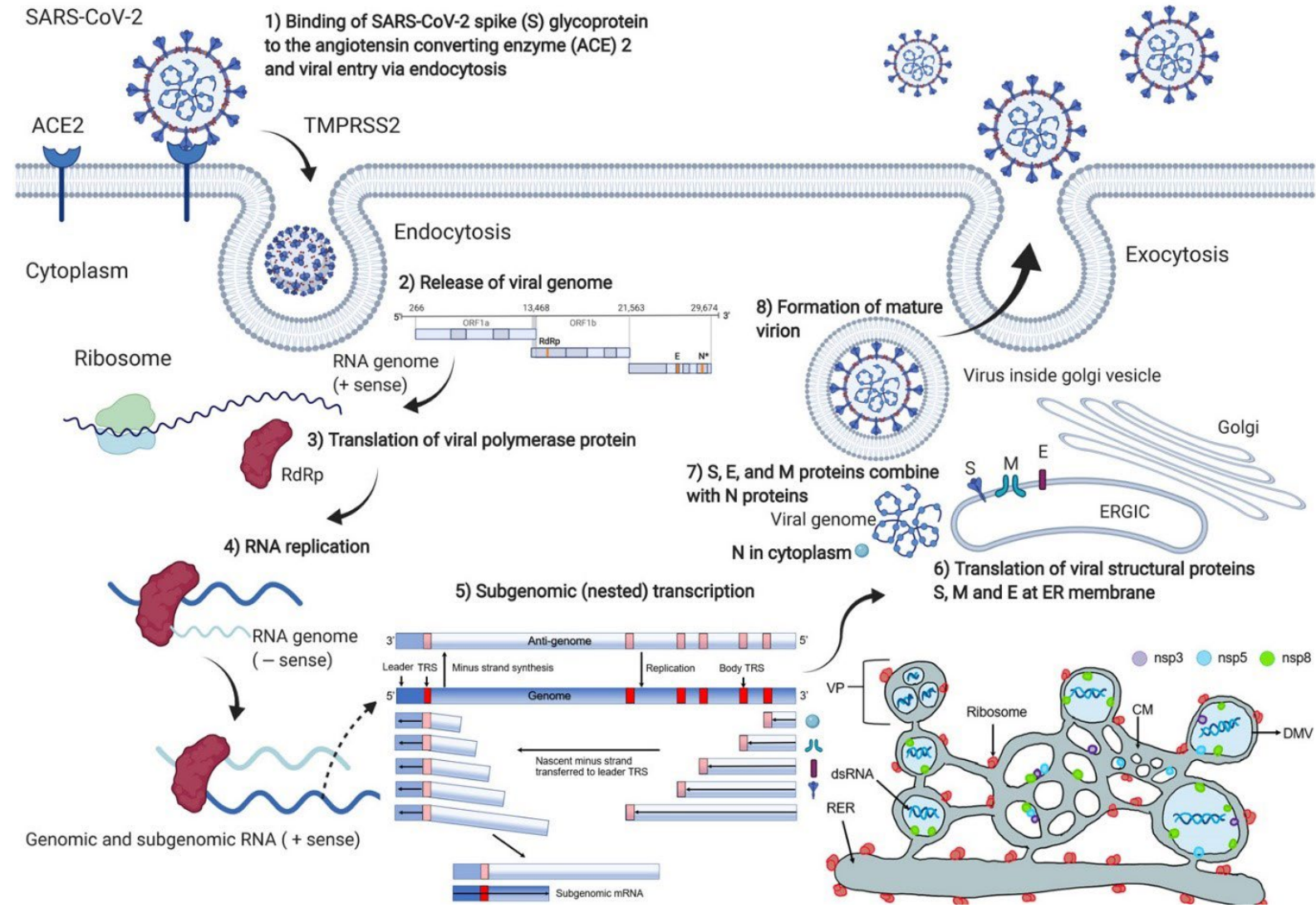

Figure 2 The infectious cycle of SARS-CoV-2. Adapted with permission from "Coronavirus Replication Cycle", ๑ BioRender.com 2020, and Ref. [440], ๑ Elsevier B. V. 2008. SARS-CoV-2 infectious cycle begins once its spike binds to the ACE2 receptors which are found in various tissues such as lungs, adipose tissue, and small intestine. After receptor binding, the host serine protease TMPRSS2 cleaves viral $\mathrm{S}$ and the viral envelope fused to cell membrane along the endosomal pathway. The viral RNA was released into the host cell and translated into polyproteins, then viral polyproteins were cleaved into small products. The viral replication proteins (16 non-structural proteins) were encoded from ORF1. Sub genomic mRNAs were initiated at the $3^{\prime}$ end of the viral genome and terminated at the TRS. The nascent transcript transferred to the complementary leader TRS through the base-pairing interaction. The transcription started from the $5^{\prime}$ end of the viral genome. RNA replication occurred on DMVs. The replicated viral genomic RNA was assembling on ERGIC membranes and formed mature virion inside Golgi vesicle. Then, they were released out through exocytosis pathway. 


\subsubsection{Neuropilin 1 (NRP1) receptor promotes SARS-CoV-2 infection to the cells}

SARS-CoV-2 spike protein has an extra loop from multiple arginine (RRAR) [30] which is required for the efficient cleavage by furin (protease in the host cell) at the R685/S686 site into S1 and S2 polypeptides (Fig. 1). The S1 polypeptide exposes the CendR motif (RXXR) binding to the b1 domain of Neuropilin 1 receptor [31,32]. Neuropilin-1 (NRP-1) is a transmembrane glycoprotein which has a role in a multifunctional receptor for many key biological processes including vascular endothelial growth factor (VEGF) signaling pathways [33, 34], coreceptors for class III Semaphorins as an essential axon guidance in primary olfactory neurons [35], and immune function [36]. Interestingly, SARS-CoV-2 uses NRP-1 as a coreceptor for promoting virus entry. S1 polypeptide is bound to both NRP-1 and ACE2 receptors then S2 polypeptide, which is anchored in the virus membrane, and is cleaved by cathepsins and TMPRSS2. As a result, S2 fusion peptide fuses viral envelope with the cell membrane [37]. NRP-1 and its homologue NRP-2 expression are found to be elevated in the bronchoalveolar lavage fluid (BALF) in severe COVID-19 cases. Nevertheless, NRP-1 expression alone causes low infectivity of SARS-CoV-2. The study shows the highest infection level of SARS-CoV-2 requires furin, NRP-1 receptor, ACE2 receptor, and TMPRSS2 [38]. The mutation in furin cleavage site (RXXR), monoclonal antibodies are raised against the NRP1 b1b2 ectodomain, a selective NRP-1 antagonist molecule (EG00229), furin inhibitors, and serine protease inhibitor could suppress the efficiency of viral infection [31,39, 40]. Thus, the nanomedicine strategies to inhibit the furin and block NRP1 b2 ectodomain are promising approaches to develop antiviral drugs $[30,41,42]$.

\subsubsection{Viability outside the host}

COVID-19 spread from human to human as shown in the first evidence came from a familial cluster who did not visit Wuhan [43]. SARS-CoV-2 is a respiratory virus that is able to spread through multiple modes including (1) contact transmission (direct contact by touching persons, e.g., handshake, indirect contact by touching contaminated objects, so called fomite transmission), (2) droplet transmission (droplet size $>5 \mu \mathrm{m}$; spread within $2 \mathrm{~m}$ distance), and (3) airborne transmission (droplet size $\leq 5 \mu \mathrm{m}$; spread greater distance than $2 \mathrm{~m}$ ) produced by coughing and sneezing from the infected patients [44-46]. Smaller aerosols are easily inhaled deposited in the lower respiratory tract (LRT) and promoting a more severe infection $[47,48]$. The virus has vitality in the air for $3 \mathrm{~h}$, causing potential airborne transmission [49], and more persistence up to one week varied on viral loads onto the object, the properties of surface, humidity, and temperature [50-52]. Outside the host cells, The virus can decay by farultraviolet light (UVC) light $(222 \mathrm{~nm})$ at $2 \mathrm{~mJ} / \mathrm{cm}^{2}$ within $25 \mathrm{~min}$ [53], heating at $56^{\circ} \mathrm{C}$ for $30 \mathrm{~min}$ [54], biocidal agents within $1 \mathrm{~min}$ such as $(78 \%-95 \%)$ ethanol, $(0.23 \%-7.5 \%)$ povidone iodine, $(0.21 \%-0.5 \%)$ sodium hypochlorite $[55,56]$. In order to stop spreading of SARS-CoV-2, social distancing, wearing mask, and keeping hands clean are the simplest ways to protect individual and community from COVID-19 pandemic during the vaccine development.

\subsection{Clinical symptoms and immune response}

The common symptoms are fever above $37.5^{\circ} \mathrm{C}$, dry cough, and fatigue $[57,58]$. The extreme cases are pneumonia, malfunction in the kidney, and respiratory distress syndrome [59]. Among the patients, losing the sense of smell (olfactory dysfunction; anosmia), distortion of the sense of taste (dysgeusia), or losing the sense of taste (ageusia) are reported $[60,61]$. The cause of sensorineural olfactory loss may be from the direct damage of the SARS-CoV-2 on the olfactory and gustatory receptors [62]. However, the COVID-19 patients will recover from the sensorineural dysfunctions within 1-3 weeks $[63,64]$. A timeline of the typical clinical symptoms is shown in Fig. 3. The average incubation time after viral infection is $4-5$ days before symptom onset $[65,66]$. The nucleic acid test (NAT) has the highest sensitivity in the early phase of illness within 7 days. Viral RNA could be detected from various clinical specimens such as nasopharyngeal and oropharyngeal swabs from upper respiratory tract (URT), sputum, endotracheal aspirate, bronchoalveolar lavage from LRT, stool, urine, and blood [67]. A positive case of COVID-19 is confirmed from respiratory samples by using reverse transcription polymerase chain reaction (RT-PCR) test $[57,68]$. However, the sensitivity of serological tests based on antibodies overtook that of NAT since day 8 after the onset [69]. The first line of defense could be detected immunoglobulin M (IgM) antibody after 3 to 6 days and peaked at 9 days and then declined in three weeks. While immunoglobulin G (IgG) antibody, a long-term immunity and immunological memory, is present in 5 days, and markedly increased in the second week after the symptom onset. It continues to elevate for the following 2 weeks [70-72]. Moreover, the sera from recovery COVID-19 patients have successful humoral responses in vitro plaque assay [73].

\subsubsection{Innate immunity of COVID-19}

The innate immunity is a broad mechanism of the host cell to control the production of virus by interferons (IFN- $\beta$ and IFN- $\alpha$ ) $[74,75]$. The viral RNA is recognized by Toll-like receptors (TLR3, TLR7, and TLR8), RIG-I-like receptors (RLRs) locate in an endosomal or cytosolic compartment. The RNA sensors trigger a signaling cascade of pro-inflammatory cytokines and induction of Type I and III IFNs (IFN- $\lambda$ ). However, SARS-CoV-2 was reported to suppress type I IFNs [13] but up regulation of type III IFNs in primary human intestinal epithelial cells [76]. In the severe case, type I and III IFNs were elevated in the lower respiratory tract. IFN- $\lambda$ contributed to the pathogenesis induced by RNA viruses. Sustained production of IFN- $\lambda$ disrupted the lung epithelial barrier leading to susceptibility to bacterial superinfections in the mouse model [77]. The implication of pathogenesis could be the IFNs responses from aging [78]. High level of inflammatory cytokines, and MCP-1 probably activated Th1 cell responses and resulted in the activation of specific immunity [57]. The clinical data suggest that the disease severity correlated with high level of cytokines (IL-6, IL-2R, and IL-10). Total T lymphocytes count decreased in a moderate case, and remarkably decreased in severe cases. [79]. Addition of Type I IFNs treatment resulting in a dramatic reduction in virus replications, confirms the disease is sensitive to Type I IFNs [80].

\subsubsection{Adaptive immunity of COVID-19}

Second line of defenses against viral infection is responsible by $\mathrm{B}$ cells and T cells. CD4 ${ }^{+}$and $\mathrm{CD}^{+}$which are subcategories of T cells were identified by their surfaces [81]. $\mathrm{CD}^{+}$was made to be specific with the anti-spike protein receptor binding domain IgG titers in two weeks $[82,83]$. The neutralizing antibody (NAbs), which considered to be a key immune product for preventing virus infection, was positively related to the spike-binding antibodies targeting S1, RBD, and S2 regions [10]. This suggests that surface glycoprotein is a powerful immunogen for developing vaccine.

\subsection{Laboratory testing to detect COVID-19}

SARS-CoV-2 could be detected by NAT, serological tests based on antibodies, Chest CT Scan, and Chest X-rays. Currently, NAT 


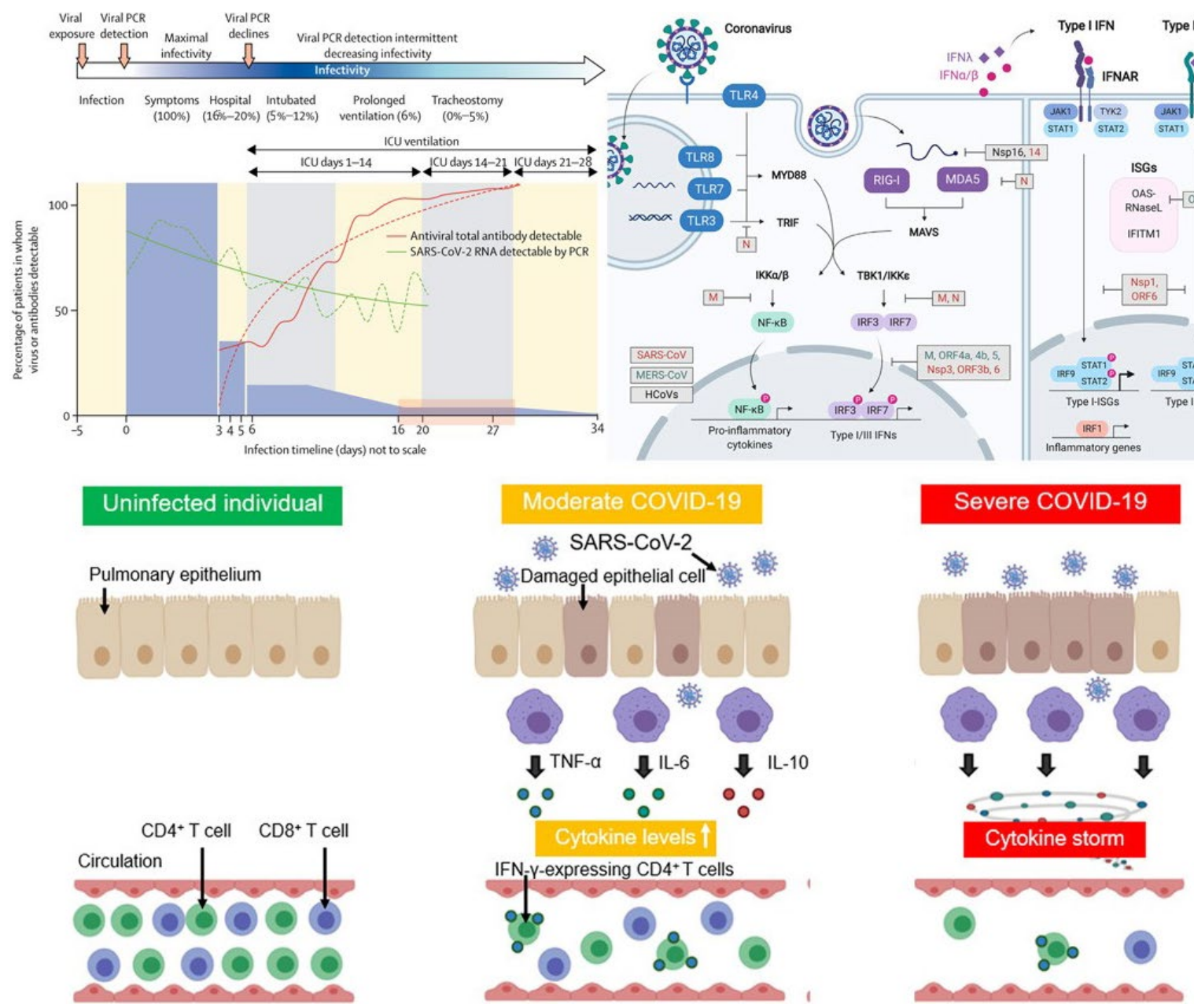

Figure 3 A timeline of the typical clinical symptoms of SARS-CoV-2 infection. Adapted with permission from Ref. [16], ๑ Elsevier B. V. 2020, Ref. [79], ๑ American Society for Clinical Investigation. 2020, and Ref. [441], @ Elsevier B. V. 2020. The average incubation time after viral infection is $4-5$ days before symptom onset. The NAT has the highest sensitivity in the early phase of illness within 7 days. However, the sensitivity of serological tests based on antibodies overtook that of NAT since day 8 after the onset. SARS-CoV-2 replicated viral genome in cytoplasm. Viral RNA was detected by TL3, TL7, TL8, RIG-I, and MDA5 receptor. The first line of defense could be detected IgM antibody after 3 to 6 days and peaked at 9 days then declined in three weeks. While IgG antibody, which is long-term immunity and immunological memory, is present in 5 days, and markedly increased in the second week after the symptom onset. It continued to elevate for the following 2 weeks. Clinical data suggest that the cytokine storm is positively correlated with the disease severity.

tests for RNA viruses include RT-PCR $[84,85]$, isothermal amplification (reverse transcription loop-mediated isothermal amplification (RT-LAMP)) [86], and Cas13-based SHERLOCK [87]. Reverse transcription polymerase chain reaction is the gold standard to screen symptomatic people due to its simplicity and easy methodology by detecting ORF1b and nucleocapsid $(\mathrm{N})$ of viral genome. The result of cycle threshold $(\mathrm{Ct})$ values above 37 is considered negative. The sensitivity of detecting viral by quantitative polymerase chain reaction can be increased (lower Ctvalue) by combining specimens from nasopharyngeal (NP) and oropharyngeal (OP) [88]. However, the collection of the LRT samples requires a skilled operator and may lead to false-negative result. Another assay method for rapid screening COVID-19 is serological assays. Serological tests for specific IgM and IgG antibodies which were produced in COVID-19 patients after the second week of viral infection can be tested with chemiluminescence assay (CLIA), immunofluorescence assay (IFA) [89], and enzyme-linked immunosorbent assay (ELISA) [90]. The main advantage of serological assay is to estimate the immune status of personal and herd immunity $[91,92]$. However, the accuracy of rapid tests and the biomarker of viral infection need to be evaluated. Computed tomography (CT) images are characterized by ground-glass opacification (GGOs). CT has been used on a massive scale to identify suspected cases with a low rate missed diagnosis of COVID-19 in China $[93,94]$.

\section{Traditional approaches to develop COVID-19 vaccine}

The goal of vaccines is to induce an immunity against an immunogen in vaccinated person so that once exposed to the natural virus, second line of defenses against viral infection will be responsive. Characteristics of an ideal vaccine should be (1) high efficacy in target populations; (2) few or no adverse reactions; (3) stimulating humoral immune responses; (4) safe for pregnant women; (5) induction of life-long immunity; (6) inexpensive manufacturing and ease of translation into developing countries; (7) reproducibility and manufacturing process; (8) stable during transportation and storage; (9) easy and inexpensive to deliver [95]. Most of COVID-19 vaccine uses surface glycoprotein (S) in SARS-CoV-2 as immunogen. The WHO has categorized COVID19 vaccines into 8 platforms: live attenuated virus, inactivated virus, replicating viral vector, non-replicating viral vector, virus like particle (VLP), DNA vaccine, RNA vaccine, and protein subunit. There are 110 candidate vaccines in clinical evaluation (8 vaccines in Phase 4, 19 vaccines in Phase 3, 9 vaccines in Phase $2 / 3,10$ vaccines in Phase 2, 27 vaccines in Phase $1 / 2$, and 37 vaccines in Phase 1) and 184 candidate vaccines in pre-clinical evaluation that are published on 13 August 2021. Comparative COVID-19 vaccine platforms with advantages, disadvantages, and added values with nanotechnology are shown in Table 1. Candidate vaccines for COVID-19 developed by using 
Table 1 A comparative COVID-19 vaccine platform with advantages, disadvantages, and added value with nanotechnology

\begin{tabular}{|c|c|c|c|c|}
\hline $\begin{array}{l}\text { Vaccine } \\
\text { platform }\end{array}$ & Immunogen & Advantage & Disadvantage & Added value with nanotechnology \\
\hline $\begin{array}{l}\text { Live } \\
\text { attenuated } \\
\text { vaccine }\end{array}$ & Whole virion & $\begin{array}{l}\text { Create a strong and long-lasting } \\
\text { immune response }\end{array}$ & $\begin{array}{l}\text { Need extensive } \\
\text { safety testing }\end{array}$ & N/A \\
\hline $\begin{array}{l}\text { Inactivated } \\
\text { vaccine }\end{array}$ & Whole virion & $\begin{array}{l}\text { Same virus particle structure as } \\
\text { SARS-CoV-2 wild type, safer } \\
\text { than LAV vaccine }\end{array}$ & $\begin{array}{l}\text { Weak immune response compared to } \\
\text { LAV vaccine, require multiple doses }\end{array}$ & $\mathrm{N} / \mathrm{A}$ \\
\hline $\begin{array}{l}\text { HAdV } \\
\text { vaccine }\end{array}$ & $\mathrm{S}$ or $\mathrm{N}$ protein & $\begin{array}{l}\text { Can infect a wide variety of dividing } \\
\text { or nondividing cells, elicit } \\
\text { strong immune responses }\end{array}$ & $\begin{array}{l}\text { Anti-adenovirus pre-existing } \\
\text { immunity in humans could reduce } \\
\text { the immunogenicity. }\end{array}$ & $\mathrm{N} / \mathrm{A}$ \\
\hline $\begin{array}{l}\text { ChAd } \\
\text { vaccine }\end{array}$ & $\mathrm{S}$ or $\mathrm{N}$ protein & $\begin{array}{l}\text { Cross-reactivity of type-specific } \\
\text { antisera with human adenovirus } \\
\text { was absent. }\end{array}$ & $\begin{array}{l}\text { Low viral yields compared to HAdV } \\
\text { during virus production } \\
\text { in HEK } 293 \text { cells. }\end{array}$ & N/A \\
\hline $\begin{array}{l}\text { mRNA vaccine } \\
\text { (conventional) }\end{array}$ & $\mathrm{S}$ or $\mathrm{N}$ protein & $\begin{array}{l}\text { Very safe, mRNA does not integrate } \\
\text { itself into the host genome. Clinical } \\
\text { applications do not involve cell } \\
\text { culture or ferme ntation. }\end{array}$ & $\begin{array}{l}\text { Short half-life, instability of mRNA, } \\
\text { transient, and low level of expression } \\
\text { of antigen-encoding mRNA require a } \\
\text { suitable delivery vehicle. }\end{array}$ & $\begin{array}{l}\text { - Protect mRNA from } \\
\text { degradation improving } \\
\text { circulation time in blood } \\
\text { - Overcome biological barrier } \\
\text { with size, charge, ligands on NPs } \\
\text { - Enhance immune responses by } \\
\text { encapsulating with adjuvants }\end{array}$ \\
\hline $\begin{array}{l}\text { Self-amplifying } \\
\text { RNA }\end{array}$ & $\mathrm{S}$ or $\mathrm{N}$ protein & $\begin{array}{l}\text { Require low doses of mRNA, } \\
\text { give high-level transient } \\
\text { expression proteins }\end{array}$ & $\begin{array}{l}\text { A large negatively charged molecule } \\
\text { and it requires a suitable } \\
\text { delivery vehicle }\end{array}$ & $\begin{array}{l}\text { - Protect sa-RNA from } \\
\text { degradation } \\
\text { - Overcome biological barrier } \\
\text { - Enhance immune responses }\end{array}$ \\
\hline $\begin{array}{l}\text { DNA } \\
\text { vaccine }\end{array}$ & $\mathrm{S}$ or $\mathrm{N}$ protein & $\begin{array}{l}\text { Stable at room temperature, } \\
\text { ability to be administered through } \\
\text { a non-invasive route }\end{array}$ & $\begin{array}{l}\text { Potential for integration of } \\
\text { the vector DNA into the host } \\
\text { genomic DNA }\end{array}$ & $\begin{array}{l}\text { - Protect pDNA, no cold-chain } \\
\text { needed } \\
\text { - AuNP encapsulated pDNA and } \\
\text { protein for skin vaccination }\end{array}$ \\
\hline $\begin{array}{l}\text { Virus-like } \\
\text { particles } \\
\text { vaccine }\end{array}$ & $\begin{array}{l}\text { Co-expression of } \\
M, E, N \text {, and } S \\
\text { protein }\end{array}$ & $\begin{array}{l}\text { Morphological mimic to the } \\
\text { authentic virus without containing } \\
\text { infectious RNA }\end{array}$ & $\begin{array}{l}\text { The structure of the resulting VLP } \\
\text { depends on the host cell } \\
\text { expression system. }\end{array}$ & $\begin{array}{l}\text { - Dry-powder for nasal } \\
\text { vaccination } \\
\text { - Targeting, imaging, and } \\
\text { enhancing immune response } \\
\text { - Biodegradable polymers }\end{array}$ \\
\hline $\begin{array}{l}\text { Subunit } \\
\text { vaccine }\end{array}$ & $\mathrm{S}$ or $\mathrm{N}$ protein & $\begin{array}{l}\text { Very safe, mimic fragment of } \\
\text { an antigen, non-infectious }\end{array}$ & $\begin{array}{l}\text { Requires multidose, and adjuvants } \\
\text { to elicit the immune responses }\end{array}$ & $\begin{array}{l}\text { enhance immunogenicity and } \\
\text { targeted of protein-based } \\
\text { vaccines. }\end{array}$ \\
\hline $\begin{array}{l}\text { Phage } \\
\text { vaccine }\end{array}$ & $\mathrm{S}$ or $\mathrm{N}$ protein & $\begin{array}{l}\text { Phage display and ability to deliver } \\
\text { pDNA vector, immunotherapies, } \\
\text { administer through a } \\
\text { non-invasive route }\end{array}$ & $\begin{array}{l}\text { Production involves bacteria } \\
\text { fermentation. } \\
\text { Precipitated phage is required to } \\
\text { remove } \\
\text { bacterial toxin and debris. }\end{array}$ & $\begin{array}{l}\text { - Protect pDNA vaccine vector } \\
\text { - Targeting, imaging, and } \\
\text { enhancing immune response } \\
\text { - Stable for oral vaccination }\end{array}$ \\
\hline
\end{tabular}

conventional platforms are shown in Table 2 and candidate vaccines for COVID-19 developed by using nano-based platforms are shown in Table 3.

\subsection{Live attenuated virus (LAVs)}

Live attenuated viruses are the serially propagated viruses in cultured cells by carefully screening the passage to minimize pathogenesis. Most live vaccines create a strong and long-lasting immune response. There are two strategies to develop LAV SARS$\mathrm{CoV}-2$ vaccines: codon deoptimized, deletion, or mutation.

\subsubsection{Codon deoptimized}

Codon usage biases are preferred codons that frequently used in highly expressed genes, commonly found in all eukaryotic and prokaryotic cells [96]. In contrast, codon deoptimization (CD) can dramatically decrease gene expression by a replacement of commonly used codons with nonpreferred codons. This approach was used to develop poliovirus (PV) vaccines [97], and influenza A virus vaccines [98]. Bioinformatic analysis of genome content and frequently codon usage in SARS-CoV-2 reveals that highly biased frequencies used codons are $\mathrm{A}$ - and $\mathrm{U}$-ending, while codons C- and G-ending are nonpreferred $[99,100]$. Genes $\mathrm{S}$ and $\mathrm{N}$ are the best targets for codon deoptimization as vaccines and antiviral drugs. Currently, Codagenix and Serum Institute of India uses codon deoptimized approach for live attenuated COVID-19 vaccines in pre-clinical evaluation.

\subsubsection{Deletion or mutation}

The defective virus in replication by deletion or mutation is one approach for developing vaccine [101]. The study in SARS-CoV by deleting 29-nucleotide in ORF8 genes resulted in decreasing virus replication up to 23 -fold when compared to the wild type. These data suggested that truncated product of ORF8 involved in attenuated viruses. It was hypothesized that the natural deletion within ORF8 genes occurred in the early stage of virus transmitting from human to human [18]. The phenomenon of nucleotide deletion in ORF8 genes was also found in new coronavirus [19]. SARS-CoV-2 variants from Vero-E6 cultured were found $15-30$ bp deletion at the S1/S2 edge [43]. One variant (Del-mut-1) has deleted 30 nucleotides (10 aa: NSPRRARSVA) within the $S$ protein leading to virus attenuation in hamster. A live vaccine with the deletion mutation as an attenuated vaccine requires high safety environmental laboratory because it can be transmitted from human to human [102, 103].

\subsection{Inactivated virus}

Inactivated virus vaccines are made by large production of virulent viruses then purified and concentrated prior to inactivation. Inactivation can be performed using chemicals such as formaldehyde, $\beta$-propiolactone ( $\beta$-PL), or physical methods such as irradiation, heat, or a combination of chemical and physical methods $[104,105]$. SARS-CoV inactivated vaccine was produced by propagating SARS-CoV strain BJ01. Infected Vero E6 cells 
Table 2 Development of candidate vaccine for COVID-19 by using conventional platforms

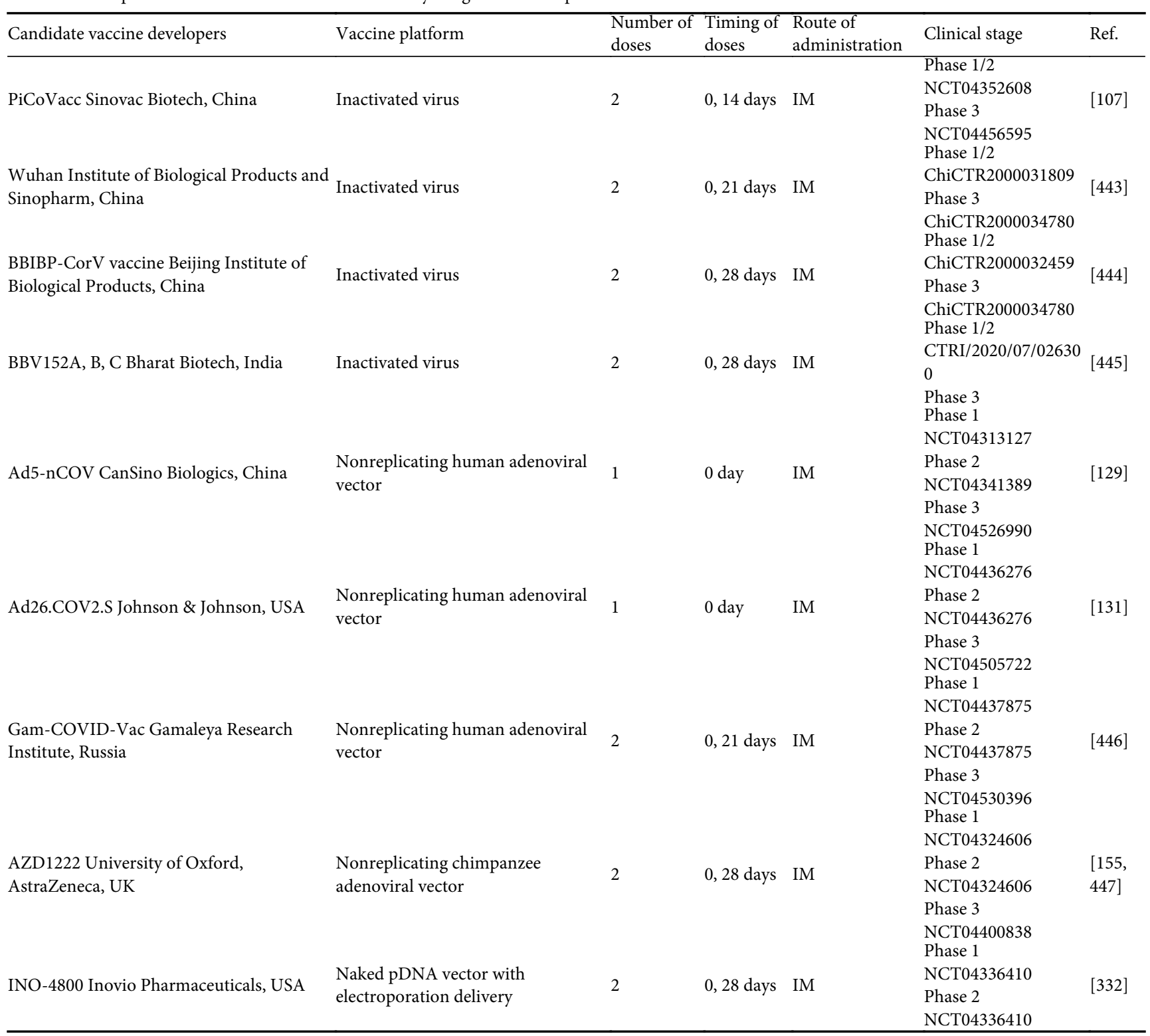

were harvested and inactivated by adding $\beta$-propiolactone and purified. SARS-CoV inactivated vaccines stimulated significant antibody responses against $\mathrm{RBD}$ in the $\mathrm{S} 1$ regions of the spike $(\mathrm{S})$ protein. Antisera were able to block receptor binding and inhibited virus entry in immunized animals [106].

\subsubsection{SARS-CoV-2 inactivated vaccine (PiCoVacc)}

PiCoVacc candidate was developed by Sinovac Biotech in Beijing. PiCoVacc was made by isolating positive COVID-19 samples from BALF. China strain $2(\mathrm{CN} 2)$ was selected to be inactivated with $\beta$-propiolactone. PiCoVacc CN2 has two amino acids substitution, E-A23D (changed from Ala to Asp at Envelope residue 23) and nsp10-T49I (changed from Thr to Ile at nsp10 residue 49). PiCoVacc CN2 has the same sequence of spike glycoprotein as wild type strain to avoid alter NAbs epitopes. The study in $\mathrm{BALB} / \mathrm{c}$ mice showed that PiCoVacc induced immune response by developing RBD-specific IgG, NAbs at week 1 after immunization without any inflammation or other adverse effects. A non-human primate study was vaccinated with two doses 3 or 6 $\mu \mathrm{g}$ at days 0,7 , and 14 then challenged 1 week later with different isolated stains of SARS-CoV-2. PiCoVacc showed fully effective at $6 \mu \mathrm{g}$ against viral infection [107]. Currently, PiCoVacc candidate vaccines reach Phase III clinical trial (NCT04456595).

\subsection{Viral vector platforms}

Viral vector-based vaccines are the viruses that are genetically engineered to safely deliver gene encoding desired antigens. Viral vector has a supramolecule size in nanoscale between $15-400 \mathrm{~nm}$. Their nucleoprotein is covered with a lipid bilayer called enveloped viruses, or not covered with a lipid bilayer called nonenveloped viruses. Viruses internalize into the cells by specific receptor binding, endosomal escape, and uncoated nucleic acids into the cellular. Viral vector-based vaccines are the viruses that are genetically engineered to safely deliver gene encoding desired antigens which are able to induce the immune systems of the host cell against the respective target pathogen [108]. Viral vector-based vaccines are categorized into two groups based on their ability to replicate. Replicating viral vector can form infectious progeny in the vaccine's cells while non-replicating viral vector fails to produce new infectious progeny particles when infecting the cell of the vaccine $[109,110]$.

\subsubsection{Replication viral vector-based vaccines}

\subsubsection{Recombinant measles vaccine (rMV)}

Measles vaccine is a negative-stranded RNA live-attenuated virus. Reverse genetics approach generates heterologous live 
Table 3 Development of candidate vaccines for COVID-19 by using nano-based platforms

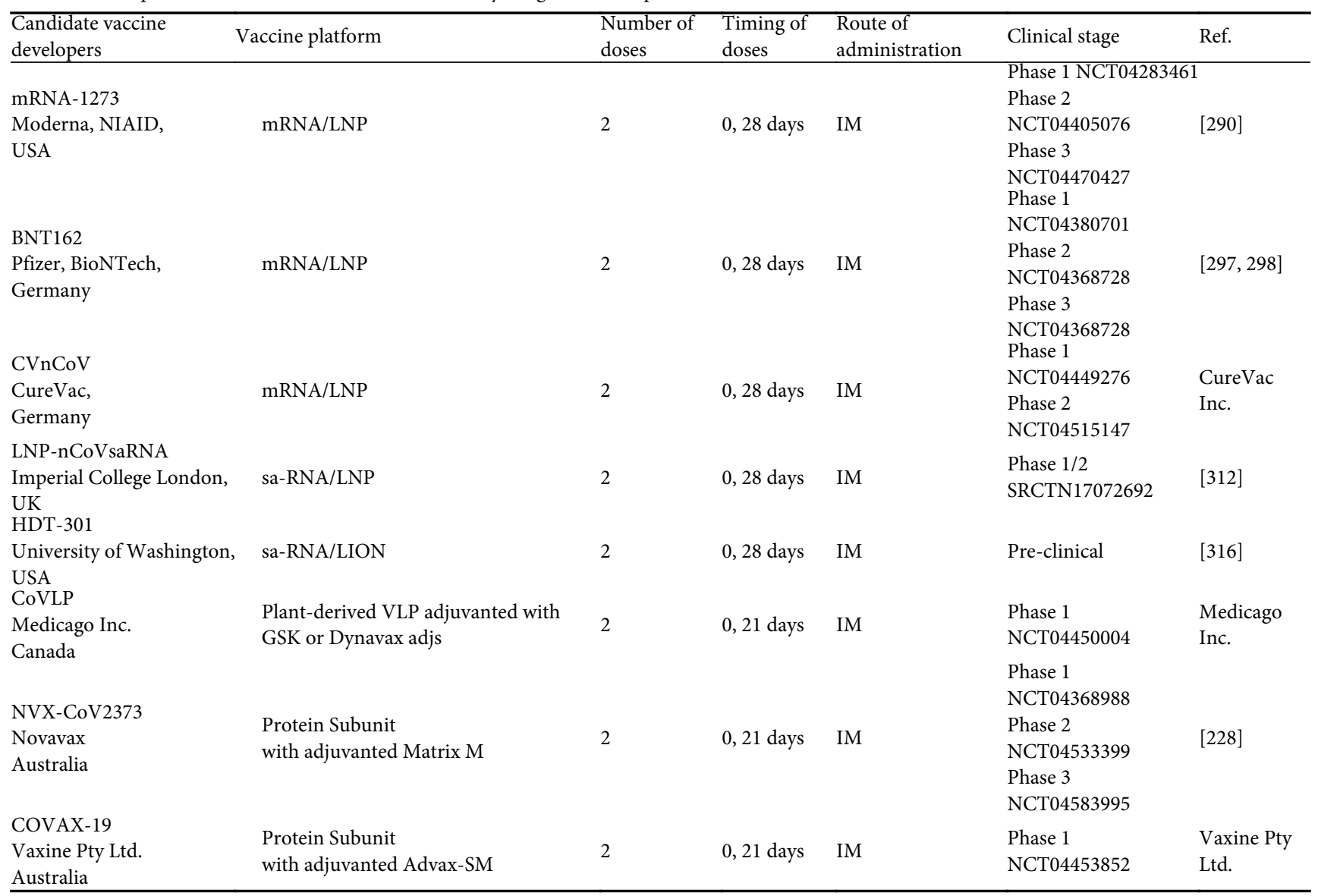

recombinant MV by using a helper cell-based rescue system [111]. This approach was used to develop MERS-CoV vaccine [112], SARS-CoV vaccine $[113,114]$, malaria vaccine [115], and HIV-1 vaccine [116]. Currently, rMV expressing spike glycoprotein SARS$\mathrm{CoV}-2$ or nucleoprotein (N) of SARS-CoV-2 is in pre-clinical phase. It was developed by a DZIF scientist at the German Center for Infection Research.

\subsubsection{Vesicular stomatitis virus (VSV)}

Vesicular stomatitis virus is a negative-sense, non-segmented, and single-stranded RNA virus with the enveloped capsid. There are three developers using live attenuated VSV-based approach to develop COVID-19 vaccines.

(1) IAVI and Merck use the same basis of Ebola rVSV vaccine which was approved by the European Commission and U. S. Food and Drug Administration (FDA). The rVSV SAR-CoV-2 vaccine candidate reaches a pre-clinical phase. (2) Rose laboratory from Yale. VSV-based SARS-CoV-2 vaccine was developed using similar approach to severe acute respiratory syndrome [117]. Currently, SARS-CoV-2 vaccine by Yale reaches the pre-clinical phase. (3) University of Western and Schulich Medicine \& Dentistry developed COVID-19 vaccine using VSV-based. Currently, VSV-based COVID-19 vaccine reaches pre-clinical phase.

\subsubsection{Horsepox}

Horsepox virus (HSPV) is an orthopoxvirus (OPV) causing poxviral disease in horses. The SARS-CoV-2 (TNX-1800) was developed by Tonix Pharmaceuticals in Canada. TNX-1800 was constructed by inserting a viral promoter and SARS-CoV-2 Spike (S) genes into sHPXV vector. TNX-1800 reached the pre-clinical phase and a vaccination by scarification in primate was initiated in the 4 th quarter of 2020 .

\subsubsection{Non-replication viral vector-based vaccines}

Non-replicating viruses have defective in the gene related to replication. In normal cells, non-replicating viral vector can express gene encoding an immunogen. To propagate, the nonreplicating viral vector requires the missing replication gene product to complement from the extra cell lines. Non-replicating viral vector vaccine includes adenovirus serotype 5 (Ad5), adenoviruses isolated from chimpanzees (ChAd), modified vaccinia Ankara (MVA), and adeno-associated virus.

\subsubsection{Adenovirus serotype 5}

Adenoviruses are nonenveloped viruses having linear doublestranded DNA (dsDNA) within an icosahedral nucleocapsid of $70-90 \mathrm{~nm}$ in diameter [118]. Their genome size is approximately $36 \mathrm{~kb}$ encoding two sets of transcriptional units: early genes and late genes. Early genes take control of the host cell and carry out viral DNA replication. Late genes express structural proteins of the virus [119-121]. There are at least 85 serotypes of human adenovirus (HAdV). HAdV 1-51 are distinguished by hemagglutination and neutralization assays [122]. HAdV 52-85 are discovered by genome sequencing and bioinformatic analysis [123]. HAdV serotypes 1, 2, 5, and 6 cause a common cold [124]. Recombinant adenoviral vectors are mostly derived from Ad5 which replicating defective constructs lacking essential viral genes $E 1$ and $E 3$. The resulting vectors have the cloning capacity of 7.5 $\mathrm{kb}$ and have the most ORF in E4 deletion excluding ORF6 that is important for Ad5 replication in HEK 293 cells $[125,126]$. Recombinant adenoviral vectors have many advantages for vaccination such as (1) adenoviruses can infect both dividing and nondividing cells; (2) high titers and easy to purify; (3) they can accommodate insertion of foreigner DNA with stability up to net genome size of $37 \mathrm{~kb}$; (4) adenoviruses do not integrate their DNA into the host genome $[127,128]$. 


\subsubsection{Ad5-nCOV}

CanSinoBIO was the first team that developed COVID-19 vaccine trial in human by using Ad5 vector platform [129]. To generate vaccine using Admax system, the spike gene (GenBank YP_009724390) with the tPA signal peptide was carried with shuttle vector, then cotransfected in 293 cells with Ad5 vectored defective in E1/E3 genes. The shuttle plasmid recombined the engineered spike gene to Ad5 vectored between loxP sites brought about the generation of viral progeny [130]. Clinical trial Phase 1 (ChiCTR2000030906) reported Ad5-based vaccine inducing TCell and antibody at day 14 and specific humoral immunity at four-week post-vaccination. However, the adverse effect was found in the high dose such as pain at the injection site, fatigue and shortness of breath. Currently, Adenovirus type 5 vector candidate vaccines reach Phase III clinical trial (NCT04526990).

\subsubsection{Ad26.COV2.S}

Ad26.COV2.S is the replication-defective human adenoviral vector serotypes 26 which was inserted SARS-COV-2 Spike (S) genes into the E1-position by $\mathrm{AdVac}^{\oplus}$ technology $[131,132]$. The Ad26.COV2.S vaccines were developed by Johnson \& Johnson in Leiden, Netherlands. The vaccines were designed in seven constructs expressing difference of spike glycoproteins. The best construct of vaccine encoding S.PP containing full-length Spike gene with wild-type SP, mutations in furin cleavage site, and $2 \mathrm{P}$ substitutions gave the highest neutralizing antibody. The study in animal model showed that single dose intramuscular (IM) injection of varied titers virus particle (VP) Ad26.S.PP elicit dose dependent $\mathrm{T}$ cells especially $\mathrm{CD}^{4+}$ and $\mathrm{CD}^{8+}$ responses. Ad26.S.PP induced a Th1-biased after 2 weeks with high titers of NAbs in Wuhan-Hu-1 strain [131], but elicited lower NAbs against the new variant strain in non-human primate model [133]. The vaccinate Syrian golden hamsters with single dose showed Sspecific and RBD-specific antibody responses at week 4 . The highest dose $\left(10^{10} \mathrm{vp}\right)$ of vaccinate animal reduces $\mathrm{TCID}_{50}$ infectious virus titers, protects against clinical disease, and no mortality after challenge [134]. A study in non-human primates (M. mulatta) that were immunized with single shot $1 \times 10^{11} \mathrm{vp}$ of Ad26.S.PP showed great results of protecting viral infection. The samples from bronchoalveolar lavage or nasal swabs confirmed negative results by RT-PCR [135]. The Ad26.S.PP is renamed to Ad26.COV2.S for validated in a clinical trial (NCT04436276). A comparative study with low-dose or high-dose of Ad26.COV2.S vaccine or placebo administered on day 1 and day 57 in healthy adults (18-55 years) showed that Ad26.COV2.S induced binding antibodies against RBD and full-length Spike protein at day 8 of post vaccination. NAbs were detected at day 15 , and continued to increase overtime on days 29,57 , and 71 of observation. The boost vaccination on day 57 increased binding antibodies and NAbs on day 71 [136]. The Phase III clinical trials are still ongoing (NCT04505722, NCT04614948). The interim results of a Phase12a trial reported that the local and systemic reactions occurred after single vaccination with either low-dose or high-dose. The mild adverse effects such as exhausted, headache, and pain in the muscle. However, the adverse effects will relieve in $24 \mathrm{~h}$. NAbs were detected in $90 \%$ and $100 \%$ at days 29 and 57 after the first vaccinated, respectively. The boost dose on day 57 provided an increase magnitude of NAbs at day 71. The boosting effect of Ad26.COV2.S after vaccination at 6 months and 1 year was still an evaluation [137]. The Ad26.COV2.S vaccine was found less effective against four variants of SARS-CoV-2 strain: D614G, B.1.1.7 (UK), B.1.351 (South Africa), and P.1 (Brazil) with the reduction of NAbs titers by pseudovirion neutralization assay (PsVNA) assay [138].

\subsubsection{Adenoviruses isolated from chimpanzees}

Simian adenoviruses (SAdVs: Latin simia meaning "ape") are the closest relatives to human adenovirus but differ in their adenovirus hexon [139]. Chimpanzees adenovirus (ChAd) was isolated from explanted of chimpanzees (Pan troglodytes) [140]. The novel simian adenoviruses were characterized and named Pan 5 (SAdV-22; GenBank AY530876), Pan 6 (SAdV-23; GenBank AY530877), Pan 7 (Chimpanzee adenovirus serotype C7 (AdC7) or SAdV-24; GenBank AY530878), and Pan 9 (Chimpanzee adenovirus serotype C68 (AdC68), or SAdV-25; GenBank AC_000011.1) [141-143]. AdC68 and AdC7 were found to benefit the clinical test because these two serotypes did not circulate in humans and lacked neutralizing B-cell epitopes. Crossreactivity of type-specific antisera with human adenovirus was absent $[144,145]$. To solve the issue of the anti-adenovirus preexisting immunity in humans which reduced the immunogenicity of human Ad5-based vaccine $[146,147]$, the scientists from University of Pennsylvania were the first team who developed a replication-defective vector based on AdC68 by deletion of E1 sequences [144]. AdC68 vector was used to develop HIV-1 vaccine [148], and rabies vaccine [149]. AdC7 vector was used to develop Zaire Ebola vaccine [150].

3.3.2.5 Chimpanzee adenoviral isolate Y25 (ChAdY25/ ChAdOx1)

Chimpanzee adenoviral strain Y25 was isolated from fecal specimens of young chimpanzees and was passed 6 times in HEp2 cells before characterization [151]. The researchers from the University of Oxford sequenced the whole genome Y25 (GenBank JN254802) and classified Y25 to be in the same cluster as that of human adenovirus E (HAdV 4) based on the nucleotide sequence in adenovirus hexon and fiber protein. Y25 was generated replication-defective vector by constructing in a bacterial artificial chromosome, which was the same method that constructed AdC68 vector. Chimpanzee adenoviral Y25 vector has a large insert capacity $(\sim 8 \mathrm{~kb})$. It was deleted in E1/E3 genes and modified in $E 4$ genes containing ORF from Ad5 to increased virus titers. ChAdY25-E construct (ChAdOX1) was selected to use in clinical trials [152] including ZIKV vaccine (NCT04015648), Influenza vaccine (NCT01818362), Tuberculosis vaccine (NCT01829490), Malaria vaccine (NCT03203421), CHIKV vaccine (NCT03590392), HBV vaccine (NCT04297917), and MERS-CoV vaccine (NCT04170829).

\subsubsection{AZD1222}

AZD1222 vaccine was developed by a similar approach for ChAdOx1 MERS [153]. To generate vaccine, the codon optimised spike (S) genes (GenBank: YP_009724390.1) with a tissue plasminogen activator (tPA) were synthesized and cloned into shuttle plasmid and recombined to destination DNA BAC vector at E1 locus of ChAdOX1 by using Gateway recombination technology [152]. The study in nonhuman primate (Rhesus macaques) after immunized with AZD1222. Spike-specific antibody was detected at two weeks after vaccinated. No pulmonary disease developed in vaccinated group after challenge with SARS-CoV-2 [154]. The study in Phase $2 / 3$ trial (NCT04400838) enrolled 560 participants aiming of finding dose frequencies and an optimal dose of vaccine administered in healthy adult. The study showed that the participants who received two doses of ChAdOx1 $\mathrm{nCoV} 19$ vaccine by intramuscular injection with low-dose $\left(2.2 \times 10^{10}\right.$ virus particles $)$ of the prime vaccination and boost vaccination with the standard doses $\left(5 \times 10^{10}\right.$ virus particles), which were given 28 days apart, had lower adverse reactions than a single dose vaccination, especially in older adults (age $\geq 56$ years) [155]. Currently, AZD1222 candidate vaccines reach Phase III clinical trial. 


\section{Nanotechnology and vaccine developments for COVID-19}

The key for the future development of COVID-19 vaccine should focus on the two main points. First, the antigens which are the important part for the recognition of the immune systems [156]. Antigens can be designed in many forms including nucleic acid (DNA or mRNA), proteins, subunits of proteins, or the fragments of viruses [157]. The good design of antigens can increase the vaccine efficacy (VE) and reduce the amounts of antigens. Moreover, the selected of conserved region of virus such as nucleocapsid [158-160] or using the bioinformatic tools to design appropriated antigens in spike proteins could prevent the variation of SARS-CoV-2 [161, 162]. Second, the carrier of antigens. The good design of carrier enhances the vaccine efficacy by improving the retention time in the blood vessel and tolerated to the degradation by enzyme before release antigens at the target sites $[163,164]$. The carrier in the nano scale is more uptake into the cells with the less toxicity which depends on its own properties $[165,166]$. The strategies to enhance vaccine efficacy by designing the nanocarriers such as lipid-based nanoparticles, biodegradable polymeric nanoparticles, dendrimers, self-assembled macromolecules, and inorganic nanoparticles will discuss.

\subsection{Role of nanotechnology}

Nanotechnology could help to combat COVID-19 by four practical applications including (1) sensors for a specific target RNA sequence of viral by modifying gold nanoparticles [167]; (2) nanotechnology-based disinfectant to prevent fomite transmission by using silver nanocluster/silica-based coating on the surface [168]; (3) nanotechnology-based encapsulated antiviral drugs adhering to the lung by using chitosan nanoparticles [169]; (4) nano-based formulation vaccines to deliver the antigens, which could be divided into two main groups: (1) organic nanocarriers such as lipid-based nanoparticles, biodegradable polymeric nanoparticles, self-assembled macromolecules, and dendrimers; and (2) inorganic nanoparticles such as gold nanoparticles and carbon nanotubes.

\subsubsection{Types of promising nanocarriers for COVID-19 vaccine development}

\subsubsection{Lipid-based nanoparticles}

Lipid-based nanoparticles primarily consisting of phospholipids can be classified according to their sizes and chemical compositions [170]. Most popular lipid-based nanoparticles that were used for vaccine delivery include liposome (phospholipid vesicles) [171], niosomes (nonionic surfactant vesicles) [172], and nanoemulsions (small lipid droplets dispersed within an aqueous phase) [173]. Lipid-based nanoparticles provide several advantages including biocompatible, less toxic, and most successful approval for clinical application, easily changing size, charge, and surface properties by modifying new ingredient formula $[8,174]$. However, drawbacks of the lipid-based nanoparticles in vivo are the rapid clearance from blood and non-specific uptake into the Reticuloendothelial system (RES) [175]. This drawback could be solved by (1) adding the surface-attached Toll-like receptor ligand (PAM and $\mathrm{CpG}$ ) targeting the dendritic cell (DC) [176]; (2) PEGylation of liposomes enhancing uptake into APCs in lymph nodes (LNs) resulting in improved efficiency of vaccines [177].

\subsubsection{Biodegradable polymeric nanoparticles}

The biodegradable polymeric nanoparticles are classified by their polymer composition in the core and their morphology for example poly(lactide-co-glycolide) (PLGA) (poly-d,l-lactide-co- glycolide), polylactic acid (PLA), and chitosan [178]. PLGA nanoparticle is the popular material for controlling released immunogen protein because of their high safety profile in human and approval by FDA [179]. The antigens can be encapsulated inside the core [180], conjugated [181], or adsorbed on the surface of the nanoparticles. The degradation of polymer occurs by the dissolution of chain fragments in noncross-linked systems when the polymer absorbs water and exchanges charges with water [182].

\subsubsection{Dendrimers}

Dendrimers are nano-sized polymeric molecules, which have branches like tree architectures consisting of a central core molecule, branching units, and end-groups (surface group). Dendrimer sizes depend on their increasing generation branch structure [183]. The advantages of dendrimers are the ability to modify the cavities to incorporate hydrophilic or hydrophobic molecules, modify the end-groups to attach peptide for targeting purposes, and they were approved for clinical applications [184]. Polyamidoamine (PAMAM) dendrimers are promising as nanocarriers of vaccines because their positive charges can form complex via electrostatic interaction with negatively charged of plasmid DNA molecules $[185,186]$. Recently, a novel amphiphilic peptide dendrimer (AmPDs) was developed for safe and effective RNA delivery. AmPDs is composed of hydrophobic two C18 alkyl chains with unsimilar composition in hydrophilic dendrons, which can self-assemble and entrap RNA molecules into nanoparticles. AmPDs-based nanocarriers form stable complex, increase cellular uptake without notable toxicity, and have better RNA releasing ability than the previous class of synthetic polymers [187].

\subsubsection{Self-assembled macromolecules}

Self-assembled macromolecules represent well-controlled biomaterial structures from molecular building blocks such as DNA origami [188], peptide [189], and protein subunit [190] to form high-order hierarchical structures. An example of selfassembled macromolecules in nature is M13 bacteriophage which can be engineered as various functional nanostructures such as sensors [191], battery components [192], gene delivery, and a promising nanomaterial for vaccine delivery by taking advantage of phage display technology [193]. The virus like particle COVID19 vaccines from Medicago Inc. is classified to be in this type of nanocarrier by expressing recombinant viral proteins and assembly in the plant expression system.

\subsubsection{Inorganic nanoparticles}

Inorganic nanoparticles such as gold nanoparticles (AuNP), silver nanoparticles (AgNP), iron oxide $\left(\mathrm{Fe}_{3} \mathrm{O}_{4}\right)$, and carbon nanotubes (CNTs) are used for various biomedical applications including imaging, targeting, antimicrobial agents, and drug delivery [194, 195]. Gold nanoparticles are promising inorganic nanoparticles for vaccine delivery of various type of antigens including nucleic acids, peptide, and proteins. AuNPs are less toxic to cells and biocompatible, high surface to volume ratio, inert and stable at room temperature. The size and shape of AuNP coated with antigens induce the different outcome of immune responses in vivo. It was found that $40 \mathrm{~nm}$ spherical AuNPs are the most effective vaccine delivery platform by enhancing antibody production compared to the cube or rod shape [196].

\subsubsection{Strategies to develop immuno-enhanced COVID-19 vaccine}

\subsubsection{Deliver antigens to the pivotal cell of immunology}

Prior to the 1980s, mechanisms involved in conferring immunity were unknown. Most vaccines used live attenuated virus. A 
discovery of dendritic cells in murine spleen cells is the big progress in cellular immunology [197]. The defend mechanism is classified into innate immunity and adaptive immunity. Innate immune is maintained by antigen presenting cells (APCs) (also called accessory cells), and their surfaces display an antigen with major histocompatibility complexes (MHCs). Recognition of an antigen by $\mathrm{T}$ lymphocytes occurs when the antigen is presented on the surface of the APCs, which include DCs, macrophages, and Blymphocytes (B cells). DCs are the "professional" of APCs that initiate primary immune responses and mediated the adaptive immune responses [198] by using synthetic peptides or soluble protein antigens to sensitize naive T cells in vitro both $\mathrm{CD} 4^{+}$[199] and $\mathrm{CD}^{+}$[200]. The theory of antigen delivery to specific receptor of DCs was proposed by Ralph Marvin Steinman. These advantages are low dose of injected protein antigen and high dose of antigen-specific $\mathrm{T}$ cells [201]. The in vivo experiments for various antigen delivery targeted to DCs were demonstrated [202-204].

4.1.2.2 A brief story of protection from antigens to immune responses

Immature DCs (iDCs) possess a strong ability of capturing and phagocytosing antigen. iDCs can take up exogenous antigens by phagocytosis [205], macropinocytosis [206], and C-type lectin family receptor at peripheral sites [207] (Fig. 4). Once the antigens internalized to iDCs and sensed from TLR [208], they can be activated and differentiated into mature DCs. Mature DCs processed in MHC class I or MHC class II pathways at the secondary lymphoid tissues. The exogenous antigens are processed in MHC class I while intercellular antigens are processed in MHC class II pathways [209]. The process stimulates $\mathrm{T}$ cells into cytotoxic $\mathrm{T}$ cells $\left(\mathrm{CD} 8^{+}\right.$cells), or $\mathrm{T}$ helper (Th) cells (CD4 $4^{+}$cells) in Thymus [210-212]. CD4 $4^{+}$plays critical roles in mediating adaptive immunity by helping $\mathrm{B}$ cells make antibody. Once naive $\mathrm{CD}^{+}$cells are processed through MHC class II pathways, the release cytokine elicits Th cell differentiation into various effector subsets including Th1, Th2, Th17, Treg, and Tht [213]. The cellular immune response to protect viruses, bacteria, and microorganism infection is mediated by IL-2, TNF- $\beta$, and IFN- $\gamma$ from Th1 cells. The Humoral immune response is mediated by Th2 cells, which increase the antibody and promote the production of IgG2a and IgG1/IgE in B cells [214]. Thus, DCs are pivotal cells of immunology by linking innate immunity with
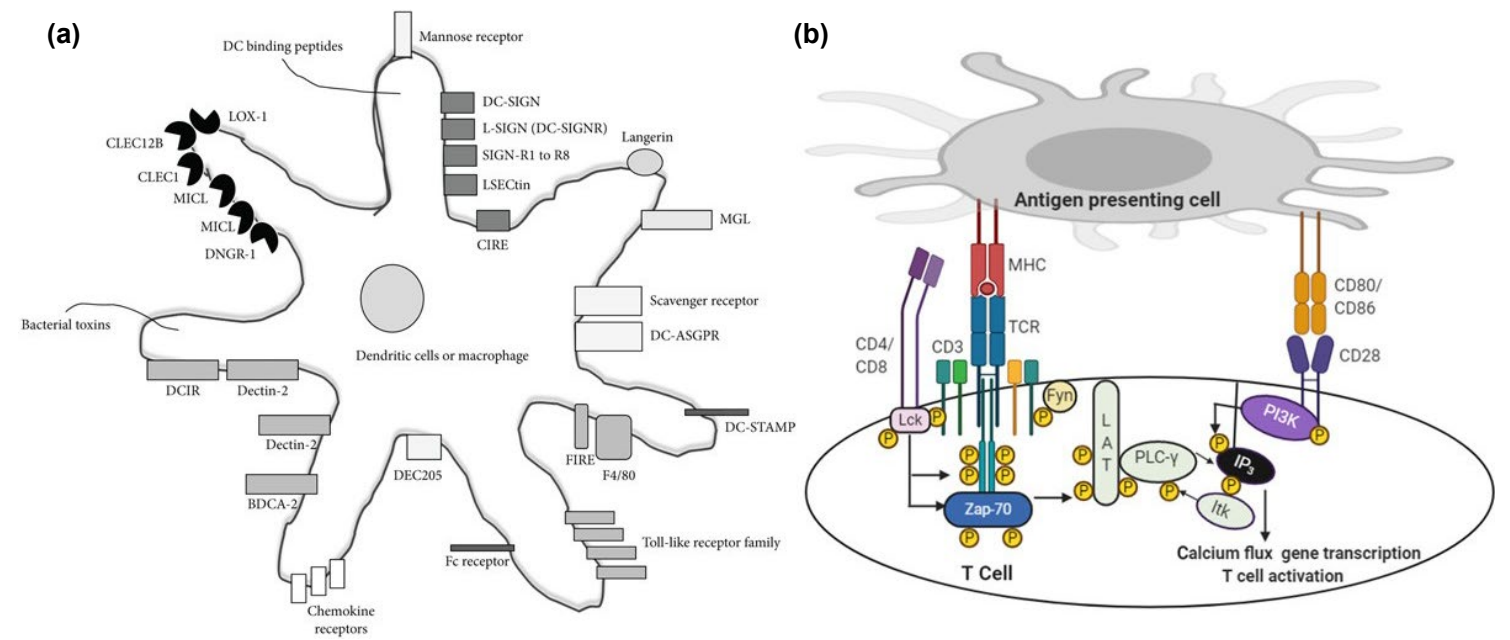

Figure 4 Surface receptors on antigen presenting cell and T-Cell activation. Adapted with permission from Ref. [213], ๑ The American Physiological Society 2013 and Ref. [442], @ Apostolopoulos, V. et al. 2013. (a). The antigens can be captured by several receptors including DEC205, Mannose receptor, and DC-SIGN. Once the antigens internalized to iDCs and sensed from TLR, they can be activated and differentiated into mature DCs. Mature DCs processed in MHC class I or MHC class II pathways at the secondary lymphoid tissues. (b) Antigen presenting cell has MHC bound with TCR. TCR is a protein complex composed of two chains, which interact with a complex $\mathrm{CD} 3$ membrane protein. $\mathrm{CD} 3$ molecules transmit activation signals to the $\mathrm{T}$ cell. adaptive immunity, and the critical role is the activation of $\mathrm{T}$ cells vaccines, the key factors are (1) how to deliver the antigen effectively; (2) DCs maturation [215]; and (3) the pathways of antigen processing [216-218]. Nanotechnology-based platform offers efficient antigens delivery formulation. Nanoparticles in the range of $20-45 \mathrm{~nm}$ are easily uptaken into lymph node APCs in vivo. Limiting size of particles to be below $70 \mathrm{~nm}$, they can remain at the site of injection [219].

\subsection{Advantages of nanovaccine}

Nanovaccine refers to the vaccine that has the particle size in nano the cell while the particle size larger than $150 \mathrm{~nm}$ will be eliminate by the reticuloendothelial system [220-222]. Nanovaccine was engineered in particle as carrier the antigens [223,224]. Viruses regarded as naturally nanomaterials which were engineered to deliver the antigens by infecting into the human cells [225]. Viruses based vaccine may compromise to the person who has the weak immune system. Nanovaccines mimic to the viruses in size and surface properties, but lack of nucleoprotein structure [226, 227] and unable to infect into the human cells will be described in this section. Comparing to the live attenuated and inactivated virus vaccine, nanovaccines have many advantages including: (1) Nanovaccine can shorten the time and save the cost for the development of a new vaccine. Nanovaccine can use the same formulation materials that were passed safety in the clinical trials to deliver new antigens of pathogen. Development of a conventional vaccine from concept to licensure nowadays takes at least 15 years [4]. For most emerging COVID-19, the obstacle is the time for developing and testing the new vaccine. Nanotechnology-based formulations of new generation vaccines can shorten the usual timeline from 15 to 20 year to 12 to 18 months to licensure of vaccines for COVID-19 (FDA-2020-D1137). (2) Nanovaccine can be administered via IM injection, intranasal spray application, and oral administration. (3) Nanovaccine can be customized on nano-carrier surfaces such as adjuvant property to increase the stimulation of the immune systems, and peptide target specific to APCs. (4) Nanovaccine removes undesired characteristics for safety by mimicking the overall structure of authentic virus particles without containing genome of virus, or unable to replicate itself in the vaccinated from naive stage. To develop immuno-enhanced Covid-19 scale. The particle in the range of $1-100 \mathrm{~nm}$ is easy to uptake into (b) 
person. Live virus vaccine has a safety issue of transmitted to contacts of the unvaccinated individuals [103] while inactivated vaccine to boost the immunity requires multiple doses. (5) Nanovaccine has a protective function. The shield of nanocarriers protects the antigen from degradation in the blood circulation system before release in the target site. (6) Nanovaccine codelivery of antigens and adjuvants result in enhancing immune activation [228].

\subsection{Nanoparticle-based antigen delivery systems}

\subsubsection{Nanomaterials properties}

Nanomaterials design is important for vaccine development to overcome biological barriers such as nonspecific distribution [229], protein corona that affects materials uptake in biological environments [230,231], and inappropriate dose threshold of antigen concentration [232] that may cause antibody dependent enhancement (ADE) [233]. The adjuvants property has increased the magnitude of an antigen-specific immune response by vaccination. Nanoparticles hold great promise for modern vaccine. NPs are defined as materials with the length of $1-1,000 \mathrm{~nm}$ in at least one dimension [234]. NPs can enter into the cells depending on its properties by using four routes: phagocytosis, macropinocytosis, clathrin-mediated endocytosis (CME), and caveolin-dependent endocytosis (CvME) [235]. However, NPs can be absorbed into the cells mainly through endocytosis because their polarity cannot cross the cell membrane, which is mostly favorable to small and non-polar molecules [236,237]. The particle sizes of materials that achieve targeting and reduced toxicity in vivo are diameters less than $100 \mathrm{~nm}$ [238]. Thus, particle size, surface charge, and shape play key roles in clearance of these nanomaterials from the body. Larger NPs are filtered out by the macrophage system after injection and accumulated in liver, spleen, and lymph nodes $[239,240]$. Toxicity of materials is another point for safety consideration. Since 2016, the number of nanomaterials that pass the safety certify by FDA for clinical trial has increased. Most of which are lipid-based nanoparticles. Different formulations in liposome composition have been synthesized to be antigen carriers, which include ligands for specific receptors, or stimuli responsive compounds on the surface [174, 241-243].

\subsubsection{Nanomaterial load antigens}

A key to success of the vaccine is to find the right immunogen to trigger an immunity with the lowest adverse effects. The term antigens ("antibody generators") and later called "immunogen" were first proposed by Paul Ehrlich. He termed antibodies are made an accidental good fit to antigens by natural body [244]. Vaccine antigens could be polysaccharides or protein of pathogen components, mRNA, DNA, or the attenuate whole live pathogens [245]. Antigens can be loaded in nanocarriers by several mechanisms such as physical adsorption [246, 247], encapsulation $[248,249]$, encapsulation with coating $[250,251]$, encapsulation with targeting mechanisms [252, 253], chemical conjugation [254, $255]$, and conjugation with targeting mechanisms [256,257]. The release of antigens can be designed by chemical properties of NPs. When acid-sensitive NPs were uptaken into the cell membrane, encapsulated antigens were released within acidified early endosomes. In contrast, acid-resistant NPs can escape endosomalprocessing events. Encapsulated antigens were released and degraded only upon delivery to lysosome [258].

\subsubsection{Targeted delivery of antigens}

The antigens can be captured by several receptors including DEC205 receptor [259], Mannose receptor [260], transferrin receptor [261], Fc $\gamma$ receptors [262], and B cell receptor (BCR)
[263]. The nanoparticles previously reported uptake into APCs such as virus-like particles [264-266], liposomes [171,267,268], and AuNPs [269-271]. NPs delivery of plasmid DNA encoded SARS-CoV nucleocapsid $(\mathrm{N})$ protein targeted to nasal dendritic cell DEC-205 receptor can reduce the amount of immunogen approximately 500-fold and administer through a non-invasive intranasal route, enhancing both humoral and cellular immune responses [272].

\subsection{Nucleic acid-based antigens}

Nucleic acid (DNA or mRNA) vaccines for COVID-19 have become a new attraction in the field of biopharmaceuticals. DNA vaccines target to the nucleus while mRNA vaccine targets to the cytosol. Thus, the mRNA vaccine approach is more rapid because it does not need to process in the nucleus. However, naked nucleic acid is a large hydrophilic negatively charged molecule. Therefore, it cannot cross the hydrophobic lipid membrane of the cells. Nucleic acid encoded antigens require an efficient delivery platform for degradation protection and cellular uptake. Non-viral vectors have been modified for nucleic acid-based antigens delivery, including cationic liposomes (lipids), cationic polymers, and cationic proteins (peptides). Key properties of synthetic delivery nanoparticles that incorporated nucleic acid are surface properties, biodistribution, and toxicity.

\subsection{1 mRNA vaccines}

The mRNA was first discovered in 1961. It has a role in intermediate template between protein-encoding DNA and protein translation process in the cytoplasm [273]. mRNA vaccines were reported to be effective for direct gene transfer in vivo for the first time by Wolff et al. [274]. However, the instability of "naked" mRNA due to easily degraded is an obstacle to develop it to be a vaccine $[275,276]$. Antigen-encoding RNA could be optimized in its stability and translatability by modifying in $5^{\prime}$ and $3^{\prime}$ UTR elements, the addition of a $5^{\prime}$ cap, and optimizing the length of polyadenylated tail (poly(A) tail) [277]. Recent advance in nanomaterials mRNA vaccine has become one of the most attractive approaches in the field of biopharmaceuticals. The mRNA vaccine has many advantages: (1) Safety. mRNA does not integrate itself into the host genome. (2) Rapid process. mRNA does not require crossing the nuclear membrane. Once mRNA reaches the cytosol, it uses the host cell machinery for translation of their sequence into the corresponding protein. (3) Production is fast, scalable, and standardized. mRNA for clinical applications does not involve cell culture or fermentation. It was synthesized and purified using a high-performance liquid chromatography (HPLC) according to good manufacturing practice (GMP) production [278]. The two types of mRNA vaccine in clinical trial include (1) non-replicating mRNA (conventional) [279] and (2) self-amplifying RNA (sa-RNA) based on an alphavirus that enables intracellular RNA amplification [280].

\subsubsection{Strategies to effectively design mRNA antigens}

A conventional mRNA antigen structure is composed of $5^{\prime}$ cap, $5^{\prime} \mathrm{UTR}$, antigen-encoding sequence, $3^{\prime} \mathrm{UTR}$, and poly(A) tail [279, 281]. To optimize the translation and stability of mRNA antigen in vivo, Yizhou Dong et al., engineered "the NASAR mRNAs" which were modified in the $5^{\prime}$ UTRs and $3^{\prime}$ UTRs regions. They demonstrated the effects of UTRs on antigen expression. For example, (1) the optimal length of the composition at the $5^{\prime} \mathrm{UTR}$ is 70-nucleotides (nt); (2) Kozak sequence (GCCACC) should be included in $5^{\prime}$ UTR for reliable starting codon recognition in mammalian mRNAs; (3) The sequence AUG within 5' UTR should be excluded for avoiding alternate translation initiation, and (4) avoiding high GC base composition in 5'UTR to decrease 
formation of secondary structures. The RNA secondary structure could be predicted from the model of free energy, thermodynamic, and deep learning neural networks [282-285]. However, the $3^{\prime}$ UTRs modified regions in their studies did not improve the translation capacity. The NASAR mRNAs derived the 5'UTR sequence from murine Rps27a gene which has the highest translation capacity per mRNA molecules, resulting in improved 5- to 10-fold more efficient translation than the control UTRs [286].

\subsubsection{Non-replicating $m R N A$ (conventional) vaccine}

\subsubsection{1 mRNA-1273 vaccine}

The mRNA-1273 vaccine is an mRNA-based antigen formulated in lipid nanoparticle (mRNA/LNP). The antigen encoding the fulllength Spike (S) protein which is prefusion stabilized in amino acid positions 986 and 987 in the S2 subunit by two consecutive proline substitutions is named as S-2P [287]. The mRNA is encapsulated in LNP using modified ethanol-drop nanoprecipitation [288]. The LNP is formulated from SM-102, cholesterol, DSPC, and PEG2000 DMG. The rapid development of mRNA-1273 takes advantages from innovative structure-based vaccine antigen design [289] and a lipid-nanoparticle delivery system. The mRNA-1273 vaccine took 63 days from sequence selection to enter Phase I clinical trial on 16 March 2020 (ClinicalTrials.gov: NCT04283461). The Phase I clinical trial aimed to validate the vaccine in a small population. 155 volunteers who were in good health were enrolled into one of thirteen groups by age and dosage. Participants received the candidate vaccine two times on days 0 and 28 by an intramuscular injection. After the first vaccination, IgG antibodies were detected at day 15 by ELISA anti-S-2, and ELISA anti-receptor-binding domain in all 45 subjects (age: $18-55$ years; each dose $N=15$; dosage: 25,100 , or $250 \mu \mathrm{g})$. The dosage 100 and $250 \mu \mathrm{g}$ had antibody dose-dependent responses. After 4 weeks of two-dose vaccinations, neutralizing antibody was measured in all subjects by using PsVNA and plaque reduction neutralization test (PRNT) assay. However, solicited adverse symptoms including headache, fatigue, and muscle pain were observed over half of the participants. At the dose of $250 \mu \mathrm{g}$, $21 \%$ participants had severe adverse effects [290]. The mRNA1273 dosage of $100 \mu \mathrm{g}$ was selected to enter Phase 3 clinical trial on 11 June 2020 (ClinicalTrials.gov: NCT04470427). The Phase 3 clinical trial enrolled 30,000 volunteers to compare the two shots of the vaccine or saline placebo to evaluate the prevention of COVID-19 for two years after the booster doses. The mRNA-1273 was $94.1 \%$ vaccine efficacy to prevent COVID-19 (Wuhan-2019 strain) [291]. However, the recent study showed that the NAbs titers in vaccinated person with mRNA-1273 vaccine were reduced significantly against the SARS-CoV-2 variant in South Africa (B.1.351), UK (B.1.1.7), Brazil (P.1), and USA (CAL.20C) $[292,293]$. Currently, mRNA-1273 vaccine for variant strain has been evaluated in the clinical trial (NCT04785144). The mRNA1273 vaccine was developed by Moderna, Inc. and the U.S. National Institute of Allergy and Infectious Diseases (NIAID).

\subsubsection{BNT162 vaccine}

BNT162 is an mRNA/LNP vaccine encoding trimerized spike protein. mRNA vaccines were designed in 4 formats (BNT162al, BNT162b1, BNT162b2, and BNT162c2) to enhance the immunogenicity in dendritic cells. Antigen-encoding RNA was modified in $3^{\prime}$ of the coding region and poly(A) tail to increase the stability [277], and superior mRNA translation in vivo by modifying nucleosides from uridine to 1-methylpseudouridine [294]. BNT162b1 and BNT162b2 showed promising results as a candidate COVID-19 vaccine by inducing neutralizing antibody, and specific T cell responses in various animal models. BNT162b1 vaccine encodes foldon trimerized $\mathrm{RBD}$ which is optimized for increasing immunogenicity by fusing with a 27 -amino acid phage T4 fibritin domain (Foldon: RBD-Fd) [295], while BNT162b2 vaccine expressed two proline substitutions (2P) in full-length spike glycoprotein [287]. The lipid nanoparticle formula was previously developed by BioNTech to deliver mRNA targeting DCs using N-[1-(2,3-dioleyloxy)propyl]-N,N,Ntrimethylammonium chloride (DOTMA) and 1,2-dioleoyl-snglycero-3-phosphatidyl-ethanolamine (DOPE) containing lipoplexes (RNA-LPX) [296]. The clinical trial NCT04368728 varied dosage administered of BNT162b1 or BNT162b2 via intramuscular injection two times: 10 or $30 \mu \mathrm{g}$ doses (booster doses 3 weeks apart) or one time $100 \mu \mathrm{g}$ dose in healthy adults (age 18-55 years; 65 to 85 years). The results showed that both vaccines elicited NAbs titres depended on the dosage. Two-time $30-\mu \mathrm{g}$ dose of BNT162b1 had the highest RBD-binding IgG and neutralizing antibodies in younger adults aged 18-55 years [297]. However, the mild to moderate systemic events (fatigue and headache) were observed after 7 days of vaccination. BNT162b2 had an advantage for the elderly (aged 65 to 85 years) with the protection and lower systemic events when compared to the BNT162b1 [298]. The BNT162b vaccine from Pfizer and BioNTech was 95\% VE against Wuhan 2019 strain [299]. The comparative study of sera samples from the vaccinated with BNT162b vaccine to the neutralization activity in SARS-CoV-2 variant found that the level of NAbs in vaccinee was reduced 3 folds in B.1.1.7, less sensitive to B.1.351 strain [300].

\subsubsection{Self-amplifying $R N A$ vaccine}

The RNA molecule which has an ability to make multiple identical copies of positive-sense single-stranded RNA (+ssRNA), resulting in exponentially more copies of RNA is sa-RNA. Most of sa-RNA vaccine vector was developed from three well-studied alphaviruses such as SIN virus, SFV virus, and VEE virus [301]. Self-amplifying RNA was engineered to solve the major problem of the conventional mRNA vaccine in vivo such as easy to degrade, short time, and the expression level of antigen-encoding mRNA is relatively low [280]. sa-RNA vaccine vectors consist of four nonstructural protein genes (nsP1-4) encoding viral replication derived from Alphavirus, subgenomic promoter, and capsid protein-encoding genes are replaced by antigen-encoding genes, thereby rendering the mRNA incapable of packaging into virus particles [302-304]. Naked sa-RNA was demonstrated as a potential nucleic acid vaccine for the first time in vivo by Peter Liljestrom [305]. Self-amplifying RNA has many advantages: (1) saRNA vaccines generated high-titre IgG responses to expressed antigens but at much lower doses (micrograms) of mRNA than non-replicating mRNA vaccine [306]; (2) sa-RNA gave high-level, transient expression proteins lasting up to two months in vivo from a single dose injection [307]. However, naked sa-RNA is a large $(9-10 \mathrm{~kb})$ negatively charged molecule and it requires a delivery vehicle for protection from blood nucleases, extended blood circulation, and efficient cellular uptake. Therefore, chemical modifications of delivery material such as mannosylation of lipid nanoparticles (MLNP) can potentially enhance uptake by APCs [308].

\subsubsection{LNP-nCoVsaRNA}

The LNP-nCoVsaRNA is an encapsulation of sa-RNA in lipid nanoparticle (sa-RNA/LNP) vaccine. The mRNA antigens encode the full-length spike proteins (GenBank: QHD43416.1) that amino acid position 968 and 969 in the S2 subunit were mutated by two consecutive proline substitutions (named K968P and V969P) [309]. To generate vaccine vector, sa-RNA based on VEE 
alphavirus [310] encoding prefusion spike was synthesized and cloned into pDNA. Self-amplifying RNAs were transcribed in vitro using template from pDNA via an enzymatic reaction. An aqueous solution of RNA was self-assembled with lipids dissolved in ethanol at $\mathrm{pH} 4$ [311]. The lipid nanoparticle capsule was formulated from Acuitas lipid, cholesterol, phosphatidylcholine, and PEG-lipid. The lipid nanoparticle encapsulated selfamplifying RNA was measured to be $\sim 75 \mathrm{~nm}$ in diameter. The pre-clinical study in animals showed that mice received two intramuscular injections, 4 weeks apart. 50- $\mu \mathrm{L}$ doses of 1 and 10 $\mu \mathrm{g}$ of LNP nCoVsaRNA generated specific IgG antibodies more than the group that injected with pDNA at the same amount at 6 weeks. The LNP-nCoVsaRNA vaccine candidate induced Th-1 and high IFN- $\gamma$ secretion [312]. Currently, the candidate vaccine reaches Phase I clinical trial (ISRCTN17072692). The volunteers who are in good health aged 18-45 years old will receive the dose escalation and evaluation of vaccine. Subjects will be followed up for 52 weeks in total. LNP-nCoVsaRNA vaccine was developed by Imperial College London, funded by Medical Research Council (UK) and UK Research and Innovation (UK).

\subsubsection{LION/repRNA-CoV2S vaccine}

The LION/repRNA-CoV2S vaccine (also called HDT-301) is formulated from lipid in organic nanoparticle (LION) and encapsulated self-amplifying RNA (sa-RNA/LION). The sa-RNA encodes full-length spike protein which was optimized codon for highly express immunogen. To generate vaccine vector, the nucleotide sequence strain Wuhan-Hu-1 position range 21,536-25,384 (GenBank: MN908947.3) was synthesized with cterminal tag and ligated to pDNA VEE strain TC-83 vector [313]. Self-amplifying RNA was transcribed in vitro using template from pDNA via an enzymatic reaction. sa-RNA was encapsulated in LION by using electrostatic interaction between the cationic from LION and anionic from sa-RNA. The LION was composed of lipid 1,2-dioleoyloxy-3-(trimethylammonium)propane (DOTAP) chloride and inorganic superparamagnetic iron oxide (SPIO) nanoparticle within a squalene oil-based emulsion. Squalene oilbased emulsion enhanced the immunity as adjuvant [314] and SPIO used for imaging, targeting, and therapy applications in vivo [315]. The LION encapsulated self-amplifying RNA vaccine was $52 \mathrm{~nm}$ in diameter. The pre-clinical study in BALB/c mice showed single IM injection of 1 or $10 \mu \mathrm{g}$ in dosage generated specific IgG antibody at 2 weeks. Moreover, both doses induced neutralizing antibodies NAbs and induced Th1 immune responses. The study in pigtail macaques with the comparative two administered LION/repRNA-CoV2S vaccine methods: (1) second shot of $50 \mu \mathrm{g}$ at days 0 and 28 , or (2) prime dose $250-\mu \mathrm{g}$ intramuscular injection. The results suggest that both methods are enough to protect non-human primates model from SARS-CoV-2 infection [316]. Currently, the candidate vaccine reaches pre-clinical. The LION/repRNA-CoV2S vaccine was developed by the University of Washington and the National Primate Research Center, and the National Institutes of Health and HDT Bio Corp.

\subsubsection{DNA vaccine}

DNA vaccine is a DNA-encoding immunogen delivered to the nucleus without using a viral vector. DNA vaccine mostly produced from plasmid DNA (pDNA) vector or minicircles (MC) vector. pDNA consists of circular DNA containing an expression cassette with the genes encoding antigens and regulatory sequence as a promoter and polyadenylation signals, and the sequences needed for propagation and selection in the bacteria. In order to improve safety, minicircles MC were developed as the next generation of DNA vectors without any selection of a marker $[317,318]$. DNA vaccines were administered into the body via various routes including direct injection, intranasal spray, and oral administration [319-321]. Once DNA vaccine reaches the nucleus, DNA sequence of antigens is transcribed to mRNAs. mRNAs are translated to proteins, and proteins induced an antigen-specific MHC, resulting in specific cellular and humoral immune responses [322]. DNA vaccine began in the 1990s. It was first demonstrated in vivo by injecting pDNA encoding an antigen leading to generated specific antibody and protective from a subsequent challenge of virus [323]. DNA vaccine has many advantages: (1) Stable at room temperature, which is necessary for transport and storage vaccine [324]; (2) easy to produce and relatively inexpensive; (3) suitable for encapsulated with various nano platforms including gold nanoparticles adsorbed on gold beads into skin $[325,326]$. Liposome-entrapped DNA facilitated their uptake by APCs in the lymphoid tissues [327]. However, DNA vaccine has a concern in a safety evaluation. It was found that DNA vector integrated into the chromosome of the received host [328].

\subsubsection{INO-4800 vaccine}

INO-4800 (also called pGX9501) vaccine is a naked pDNA vector, which uses synthetic DNA-based vaccine approach to accelerate developmental timelines. INO-4800 was administered via intramuscular injection and used electroporation (EP) technique to deliver the DNA vector into the cell. The EP uses millisecond (ms) electric pulses to create a reversible pore on the cell membrane that allows pDNA vector to enter in different kinds of cells including muscle, skin, and APCs. By receiving electroporation, the vaccine efficacy could increase up to 100 -fold $[329,330]$. To generate pDNA vaccine vector, the four genomic sequences annotated of SARS-CoV-2 spike glycoprotein were retrieved from GISAID database and aligned. Three genome sequences were similar identity, and one was $98.6 \%$ matched identity with the others (named: outlier). The fully matched sequence was added of the $\mathrm{N}$-terminal IgE leader sequence to enhanced targeting Trans-Golgi network (TGN) [331], then used a codon optimization tool to generate DNA sequences that enhanced protein expression. The optimized codon was synthesized and ligated into the expression cassettes consisting of CMV promoter and bgh-PolyA tail, resulting in INO-4800 vector. The outlier was constructed with the same methods, designated as pGX9503. The pre-clinical study in mice model after immunization with twice shot of vaccine on days 0 and $14(2.5 \mu \mathrm{g}$, or $10 \mu \mathrm{g}$ ) showed that IgG binding against viral spike protein in the RBD regions, and $\mathrm{S} 1+\mathrm{S} 2$ regions were detected at 2 weeks. Moreover, specific $\mathrm{T}$ cells were detected at day 7 and superior at dosage $10 \mu \mathrm{g}$ on day 10 . PRNT assay showed that sera from mice at day 21 could neutralize the viruses, suggesting a successful humoral response [332]. INO-4800 vaccine was developed by Inovio Pharmaceuticals. Currently, the INO-4800 candidate vaccine reaches Phase I/II clinical trial (NCT04336410).

\subsection{Virus-like particle}

The structures that composed of multiprotein mimic the authentic virus particles, but exclude the genetic material of the virus is termed virus-like particles [333]. VLPs are monodisperse, defined by the surface chemistry and the VLPs self-assembly from nanoparticles subunits to form high-order hierarchical structures. The idea of protein engineering has started since 1980s with the purposes to synthesize enzymes, redesign antibodies, analyze molecular recognition, and determine structure-activity relationships [334]. Due to the fact that virus like particles are selfassembled structural proteins in the heterologous host expression system, VLPs have antigenic and morphology properties comparable with the native virus. To study the mechanism of viral 
infection, VLPs are used as a model for interaction between viruses and cell tropism $[335,336]$. The capsid of a virus has been engineered as nano-containers including drug delivery [337], constrained polymer synthesis, and catalysis [338]. The interest in VLPs was inspired by the successful development of recombinant VLPs carrying hepatitis B virus surface antigen ( $\mathrm{HBsAg}$ ) which formed $22 \mathrm{~nm}$ non-infectious particles in yeast [339].

\subsubsection{Advantages of virus-like particle vaccines}

Virus-like particles have many benefits as an antigens delivery platform. First, VLPs are safer than live virus because they are mimic the authentic virus without the genetic material (DNA/RNA) making them unable to replicate or cause infection. Second, VLPs have nano size between $22-150 \mathrm{~nm}$ which are easy to enter the APCs to stimulate B cell and T cell responses [340]. Third, the epitopes of VLPs display as native of viral particles resulting in the NAbs are stimulated precisely. Fourth, VLP-based vaccines can be produced in large scale [341].

\subsubsection{Strategies for SARS-CoV-2 VLPs engineering}

Coronaviruses are among the largest enveloped RNA viruses, and SARS-CoV-2 are measured to be $60-140 \mathrm{~nm}$ in diameter. Virus particles have quite distinctive spikes, about 9-12 nm [342]. Coronavirus virus-like particles (CoVs VLPs) based-vaccine is constructed by recombinant expression of the structural proteins: Spike (S), Envelope (E), Membrane (M), and Nucleocapsid (N) proteins in baculovirus expression system [343], mammalian cells [344], and plant cells (Medicago Inc.). The baculovirus expression system in insect cells is the most suitable for efficient expression of complex protein structures that require posttranslational modification such as glycosylation, phosphorylation, and acylation $[345,346]$. Dissimilar to other enveloped viruses, the coronavirus assembles and buds intracellularly at the ERGIC (Fig. 2). The SARS-VLPs are isolated from cell lysates [347].

\subsubsection{Component proteins for SARS-CoV-2 VLP}

The minimal requirements for the assembly of SARS-VLPs are membrane (M) protein, envelope (E) protein, and nucleocapsid (N) proteins [348]. To generate SARS-CoV-2 VLPs based-vaccine, the minimal system for efficient formation and release VLPs are $\mathrm{M}$ and $\mathrm{E}$ proteins [344]. Nevertheless, $\mathrm{S}$ proteins and $\mathrm{N}$ proteins have been used as the leading target antigen in vaccine development.

S protein: The Spike glycoprotein of the viral has the major role in triggering the immune responses of host cells including neutralizing antibody and cellular immunity against SAR-CoV [349] and SAR-CoV-2 [350]. However, IgG and neutralizing antibodies against SARS-CoV do not persist and drop within 3 years [351] whereas $\mathrm{N}$ proteins are highly immunogenic and inducing specific $\mathrm{T}$ cells could be presented up to 11 years [158].

N protein: Although nucleocapsid proteins are shared $90 \%$ similarity on amino acid sequences among coronaviruses, new reports have shown that SARS-CoV-2 adjusts in the electrostatic surface characteristics [159]. Moreover, specific T-cells were assayed frequently targeting nucleocapsid $(\mathrm{N})$ proteins as well as non-structural proteins NSP7 and NSP13 [352].

$\mathrm{M}$ protein: The membrane proteins interact with nucleocapsid and spike protein during the assembly of viruses. Mutation in membrane proteins has effects on VLPs assembly [353].

E protein: The envelope protein has the tiny size, but it has the major role on virion assembly. The study by constructing SARS$\mathrm{CoV}$-VLP lacking $\mathrm{E}$ protein significantly reduces viral titres and lowers the number of mature virions $[354,355]$.

4.5.4 VLPs display antigens
There are four strategies for engineering VLPs display antigens.

(1) Gene fusion technique

The advantage of this strategy is displayed epitope in quaternary structure, requiring less processing, the capsid self assembles in vivo, and homogeneous protein nanoparticles. VLPs allow the fusion of foreign antigens at $\mathrm{N}$ or $\mathrm{C}$ terminal to display the epitope with high immunogenicity [356]. VLPs can also act as effective platforms targeting DCs in vivo by fused lymphocytic choriomeningitis virus (LCMV) peptide gp33 [KAVYNFATM] $[357,358]$. The SARS-CoV-VLPs can be fused with foreigner peptide by removing amino acid (aa) 1,196-1,255 in spike (S) protein (GenBank: AAP13441) and replacing with amino acid from influenza hemagglutinin. The fused SARS-CoV-VLPs increased significantly yield [359].

(2) Chemical coupling of antigens to the VLP surface

A common approach is through cross-linking of lysine residues on the VLP surface to cysteine residues present into the antigen by using n-hydroxysuccinimide (NHS) ester reactions [360]. Various antigens such as peptides, proteins, carbohydrates, and lipoproteins were coupled to the VLPs surface through chemical reactionand bonding lysine [361]. Surface mannosylation of VLPs by conjugating the mannoside or dimannoside to the lysine residues can significantly enhance binding and internalization by APCs, leading to improved immune responses [264]. However, the VLP surface often contains multiple lysine residues. Modification by NHS ester reactions may lead to an uneven antigen distribution and a little control over antigen orientation or may cause antigen misfolding.

(3) Affinity-based conjugation

This approach uses high-affinity binding interactions between biotin and streptavidin, or interactions between His-tag and $\mathrm{Ni}$ NTA. Affinity-based conjugation has an advantage to display large and complex vaccine antigens without compromising VLP formation and stability. To generate recombinant proteins biotinylated, an amino acid sequence GLNDIFEAQKIEWHE was added in the region of coating protein that was not compromised VLP-assembly, allowing VLPs surface to dock monovalent streptavidin fused antigen to the biotin [362]. Biotinylated fused spike protein was constructed by fused Spike (S) protein (GenBank: QHD43416.1) amino acid position Val 16-Arg 685 with poly-His and AviTag ${ }^{\mathrm{TM}}$ sequence.

(4) Peptide-protein (Tag/Catcher) conjugation

The Tag/Catcher conjugation was developed based on a splited protein CnaB2 from S. pyogenes (named: SPY). CnaB2 splits into two fragments to enable peptide-protein ligation. The small fragment named SpyTag has short peptide 13 aa, and protein binding partner named SpyCatcher has 138 aa. Once mixed into a solution, the SpyTag and SpyCatcher rapidly covalently conjugate to each other through an isopeptide bond [363]. In order to decorate peptide on VLPs, the SpyCatcher protein is engineered to form covalent bond to the SpyTag peptide. SpyCatcher was fused to coating protein and produced SpyCatcher-VLPs in an expression system. SpyTag peptide was fused at the C-terminus of antigen for example anti-DEC205 scFv. By simple mixing SpyTag/SpyCatcher, resulted in display targeting DCs peptide on VLPs $[364,365]$.

\subsubsection{Expression systems for VLP production}

Viral capsid has produced in various expression systems such as bacteria [366,367], yeast [368], plant [369,370], insect cells [346, 371], mammalian cells [372,373], and cell-free platform [374]. To generate immunogenic virus-like particles, popular choices of eukaryotic expression systems are insect cells, mammalian cells, and plant cells.

In baculovirus/insect cell system, it can provide 
posttranslational modifications (PTM) for SARS-CoV-2 protein such as N-glycosylation [375, 376]. However, a disadvantage of this system is contaminating baculovirus particles. For safety, inactivation of baculoviruses and purification for VLP are required [377].

In mammalian cells expression system, VLP has PTM and assembly similar to authentic virus [378]. Nevertheless, the production cost of mammalian cells at large scale deployment is higher than the other systems.

In plant expression systems, the advantage is the low risk of introducing adventitious human pathogens and cost-effectiveness for large-scale deployment. However, the drawback of this system is low VLP expression and PTM unlike authentic virus due to plant-specific N-glycosylation of glycoproteins [379,380]. Thus, the choice of the host cell expression system has consequences both in terms of the structure of the resulting VLP and the cost of production process [381].

\subsubsection{Virus-like particle vaccine for SARS-CoV-2}

\subsubsection{Plant-derived virus-like particle}

The idea to use plants as mini factories to produce vaccine started in 1980s. It was inspired by the success expressed recombinant antibodies in tobacco [382]. Australian tobacco (Nicotiana benthamiana) is most widely used as susceptible host due to the good efficiency in genetically transformation. Ability to express foreign genes from a plant virus vector and yield of purified protein were acceptable [383]. The first plant-derived virus-like particle vaccine displayed hepatitis B surface antigen with an average diameter of $22 \mathrm{~nm}$ [384]. Plant VLPs received increasing attention in clinical trials because the nano particles were biocompatible, biodegradable, low-risk of introducing human pathogens, and can be chemically and genetically engineered to target [385, 386] and imaging [387].

\subsubsection{CoVLP vaccine}

CoVLP vaccine is a plant-derived SARS-CoV-2 virus-like particle. It was developed based on the transient Agrobacterium-mediated expression of viral structural proteins in tobacco $(N$. benthamiana). This approach was used to produce influenza vaccines $[388,389]$. To generate vaccine, genes encoding SARSCoV-2 structural proteins were synthesized and cloned into plasmid. The recombinant plasmid was transferred into bacteria Agrobacterium tumefaciens as a vector to create transgenic plants. $N$. benthamiana were vacuum infiltrated in batches with an Agrobacterium inoculum containing a SARS-CoV-2 expression cassette. Upon bacteria inside the tissue, Agrobacterium transfers recombinant DNA to the nucleus. Inside the nucleus, the T-DNA was transcribed into mRNAs without integrated into the plant genome [390,391]. mRNAs can be exported into the cytoplasm whereas transient expression protein and self-assembly into VLP. Tobacco was incubated up to eleven days before harvested plant leaves and purified. The production process was only 20 days to obtain vaccine. CoVLP had $\sim 100 \mathrm{~nm}$ in diameter. Currently, the candidate vaccine reaches Phase I clinical trial (NCT04450004). CoVLP was developed by Medicago Inc. and Laval University Infectious Disease Research Center in Canada.

\subsubsection{Mammalian-derived virus-like particle}

SARS-CoV-2 VLP was constructed by expressed viral structural proteins in mammalian cells. To generate plasmid, the genes encoding spike protein (GenBank: QHD43416.1), membrane protein (GenBank: QHD43419.1), envelop protein (GenBank: QHD43418.1), and nucleocapsid protein (GenBank: QHD43423.2) of SARS-CoV-2 with C-terminal tag, and restriction bases at $5^{\prime}$ and $3^{\prime}$ terminal were synthesized and cloned into expression plasmid. The four plasmids were co-transfected with commercial transfection reagent in mammalian cell line 293T or Vero E6. Mammalian-derived virus-like particles were separated by sucrose gradients and ultra-centrifuged. $\mathrm{Xu}$ et al. reported the necessary two structural proteins for assembly SARSCoV-2 VLPs were membrane protein $(\mathrm{M})$ and envelope proteins (E). Moreover, this study reported that VLPs produced form Vero E6 cells had a diameter $\sim 71 \mathrm{~nm}$, smaller than that in HEK-293T cells (diameter $\sim 90 \mathrm{~nm}$ ), but the spike (S) from Vero E6 was precisely shape of trimeric spikes. Their results suggested that Vero E6 cells were appropriate mammalian cells to produce VLPs [344]. Mammalian-derived SARS-CoV-2 virus-like particle was developed by the China Academy of Chinese Medical Sciences.

\subsection{Subunit vaccine}

A fragment of an antigen protein, typically Spike in SARS-CoV-2 used to stimulate an immune response without introducing overall structure of virus particles is termed subunit vaccine. To produce a subunit vaccine containing only spike $(\mathrm{S})$ protein, the conventional approach used a detergent as sodium dodecyl sulphate (SDS) to solubilize proteins from membranes. However, the conventional approach was more difficult to achieve [392]. Recent advance in biotechnology has accelerated the subunit vaccine development including modification protein solubility, protein stability, and improved immunogenicity by fused foreigner peptide or proteins [393]. The advantage of subunit vaccine is low risk. However, individual subunit vaccine is less effective than VLP vaccine due to their rarely present epitopes in their native conformation $[379,394]$. Moreover, subunit vaccine often requires multidose, followed by booster doses, as well as codelivery of adjuvants to elicit the necessary immune responses [395]. In order to enhance immunogenicity and targeted of protein-based vaccines, numerous biodegradable polymers have been designed to deliver subunit antigens including polymeric micelles [396,397], polyacrylate dendritic polymer [398], and PLGA particles [399].

\subsubsection{NVX-CoV2373}

The vaccine composing of spike subunit protein and adjuvant Matrix-M. To generate vaccine, the nucleotide sequence of spike gene (GenBank: MN908947.3) was codon optimized to express in Sf9 cell. The optimized sequence was synthesized and cloned into baculovirus transfer vector, designated as wild type (WT). NVXCoV2373 baculovirus transfer vector was generated by double mutant in WT: (1) Mutation at furin cleavage site using site directly mutagenesis from amino acid RRAR to QQAQ at the position 682-685, resulting in furin protease resistance [25] and (2) mutated the amino acid from $\mathrm{K}$ to $\mathrm{P}$ at position 986 and $\mathrm{V}$ to $\mathrm{P}$ position $987(2 \mathrm{P})$ to stabilize spike protein in a prefusion conformation [287]. Double mutant Spike proteins were produced using a recombinant baculovirus infected Sf9 cells and harvested at $72 \mathrm{~h}$ post infection. Purified NVX-CoV2373 Spike proteins forming $27.2 \mathrm{~nm}$ nanoparticles increase the affinity to bind the ACE2 receptor, thermostable and tolerated to the proteolytic cleavage [228]. The adjuvant Matrix-M composed of saponin oil from Quillaja saponins, phospholipid, and cholesterol encapsulated in nanoparticles. Matrix-M has demonstrated induction lymphocyte cells and substantially greater levels of neutralizing antibodies in vivo both in animal [400,401] and clinical trial $[228,402]$. However, the Matrix-M can only administrate via IM injection [403]. NVX-CoV2373 vaccine from Novavax composed of polysorbate 80 (PS80) as a core to hold the subunit proteins with hydrophobic interaction then further coformulated with the saponin adjuvant which is able to dissolve in 
lipid and water [404]. The adjuvant Matrix-M was mixed with NVX-CoV2373 prior vaccinate. The study in healthy adults aged 18-59 years segmented by dosage (Placebo-Saline, 5 and $25 \mu \mathrm{g}$ ) and Matrix-M adjuvant dosage (0 and $50 \mu \mathrm{g})$ administered vaccine or placebo twice doses on day 0 and day 21 by an intramuscular injection $(0.6 \mathrm{~mL})$ showed that two-dose NVX$\mathrm{CoV} 23735 \mu \mathrm{g}$ with adjuvanted Matrix-M induced anti-spike IgG and neutralization antibodies that higher than the convalescent from recovered patients. No adverse events were observed. The vaccinated participants have mild reactogenicity with the average of 2 days [228]. NVX-CoV2373 was 49.4\% VE against COVID-19 in the clinical trials at South Africa which major strain is B.1.351 [404]. The safety and efficacy of vaccine to prevent COVID-19 in pediatric (12-18 years) is currently study (NCT04611802).

4.6.2 COVID19 recombinant spike protein with Advax-SM adjuvant (COVAX-19)

COVAX-19 vaccine composed of SARS-CoV-2 spike subunit protein with ADVAX adjuvant. COVAX-19 has also used the same approach that developed vaccines against SARS-CoV. SARS$\mathrm{CoV}$ subunit vaccine lacks thetransmembrane and cytoplasmic domains of spike [405-407]. To generate vaccine, nucleotide sequence encoding truncated spike was optimized to express recombinant protein using baculovirus system. Advax adjuvant was formulated with antigen by simple mixture immediately prior to immunization. Advax adjuvant is plant-based polysaccharide comprised of inulin polymer. The crystalline (gamma) inulin has ability to increase C3 deposition on antigen-presenting cell, resulting in enhanced antibody and T-cell immune responses $[408,409]$. Currently, the candidate vaccine reaches Phase 1 clinical trial (NCT04453852). Forty volunteers who are in good health, aged between 18 and 65, will receive two doses of vaccine $25 \mu \mathrm{g}$ with adjuvant, or placebo (saline) by intramuscular injections. COVAX-19 was developed by Vaxine and Flinders University in Australia.

\subsection{Phage-based vaccines}

Bacteriophage therapy has been used to combat bacterial infections in human since the discovery in 1940 because their safe and high specificity towards the target and have no effect on nontarget. Phage can be administered by oral, intraperitoneal injection, intramuscular injection, subcutaneous injection, and medullary injection. M13 bacteriophage (phage) was classified in the genus Inovirus (family Inoviridae). Phage has long, thin filamentous shape with nano-size [410]. Recent advances in the genetic engineering pave a way to develop phage as novel nanobiomaterials to deliver nucleic acid as therapeutic agents for silencing expression of genes or restoring the expression of nonfunctional gene with highly specific, less toxicity, and low-cost production. Phage genome can be engineered to display functional peptide motif on their minor (pIII) and major coat proteins (pVIII), encoding the antigen of interest for vaccines and immunotherapies. The advantage of phage genome is the ability to directly display between genotype and phenotype. This technology demonstrates a new strategy for nano-vaccine delivery platforms. Previously, AAVP vector has demonstrated to display foreigner peptide on the minor coated protein [411] and major coated protein [412]. There are two strategies to develop phage-based vaccine: (1) Phage-based vaccine can mimic to display antigens on their coated protein surface, or (2) display peptide target to the antigen presenting cells and deliver DNA-encoded antigens. Phagebased vaccine has a potential for immunotherapy including cancer [413, 414], malaria [415, 416], and Alzheimer [417].

\section{Promising candidate COVID-19 vaccines}

Clinical trials are experimental conditions with randomization designed and controlled by scientists to answer the specific questions such as dosage, timing, safety, and effectiveness of vaccines, drugs, or devices in human subjects [418]. There are 5 stages (phases) of the study before commercial approval by FDA. (1) Pre-clinical evaluates the safety and doses equivalent of vaccine in animal studies. For small animal models, it was found that SARS-CoV-2 could not infect through wild type mouse ACE2 receptor. There are three ways of testing vaccine efficacy: using transgenic mouse replaced with human ACE2 gene [419]; using adapted strain for mice (MASCp6) [420]; using Syrian hamster which is an alternative small animal model [421]. For large animals models, ferrets were used to prove direct contact [422] and airborne transmission [423]. The most popular model for testing vaccine in the non-human primate model is Rhesus macaque, which provides valuable data of protective efficacy after challenge with SARS-CoV-2 [424]. (2) Phase I trial (doseescalation) is the first study in a small group of humans (20-100 subjects; at least 3 placebo) to find recommended dose (RD), the maximum tolerable dosage (MTD), and investigate the outcome protective immunity and dose-limiting toxicity (DLT) [425]. (3) Phase II trial (therapeutic exploratory) is in larger human subjects than Phase I trial (500 subjects; at least 125 placebo) to test pharmacokinetics, pharmacodynamics, and safety. It was designed to find dose frequencies and optimal dose for planning the Phase III trial [129]. (4) Phase III trial (therapeutic confirmatory) aims to confirm the therapeutic efficacy in large number of human subjects (300-3,000 subjects randomly assigned 1:1). (5) Phase IV trial (post marketing study) aims to conducted vaccine safety profile after vaccine was approved by FDA for commercial [426]. The amount of subjects has an important role in statistical power to detect the adverse reaction no less than 1 subject in 100 subjects after vaccination $[418,427,428]$. Vaccine efficacy is the critical outcome of FDA approval (FDA-2020-D-1137) that should not be less than 50\% to prevent COVID-19 [429]. Nano-based vaccines have shown the most promising result in Phase III trial higher than the FDA standard. The lipid nanoparticle encapsulated mRNA-based (mRNA/LNP) BNT162 vaccine from Pfizer and BioNTech reported $95 \%$ efficacy. The vaccine efficacy was calculated from the 38,955 subjects who received the vaccine and placebo in the randomize design 1:1. The data were collected from 170 subjects that later confirmed positive SARS-CoV-2. The risk of disease after vaccination was $0.041 \%$ ( 8 positive subjects from 19,478 subjects), while the risk of disease in non-vaccinates was $0.832 \%$ (162 positive subjects from 19,477 subjects). The risk ratio was $0.049(0.041 \%$ risk of disease in vaccinates: $0.832 \%$ risk of disease in non vaccinates). Thus, the vaccine efficacy was approximately 95\%. However, the challenge for the mRNA vaccine in clinical application was a need for cold chain storage and transportation. The $\mathrm{BNT} 162$ vaccine must be kept at $-70{ }^{\circ} \mathrm{C}$ for 6 months and $2-8{ }^{\circ} \mathrm{C}$ in refrigerator up to 5 days before vaccination to ensure vaccine potency (Pfizer Inc). The mRNA1273 vaccine from Moderna had $94.5 \%$ vaccine efficacy, which was calculated from 30,000 subjects. The vaccinated group had 5 positive subjects while the placebo group had 90 positive subjects. The lipid nanoparticle encapsulated mRNA-based (mRNA/LNP) formulation mRNA-1273 vaccine could be kept at $-20{ }^{\circ} \mathrm{C}$ for 6 months and $2-8{ }^{\circ} \mathrm{C}$ in refrigerator up to 30 days (Moderna Inc). AZD1222 (ChAdOx1 nCoV-19 vaccine) reported 90\% efficacy when administered with 2-time doses with a prime-boost at lower doses and boost with standard doses at 28 days apart $(n=2,741)$ while administering 2 times with the prime and boost standard doses decreased the vaccine efficacy to $62 \%(n=8,895)$. The 
explanation of dose-dependent administered was not clear, however, AZD1222 had an average efficacy of $70 \%(n=11,636)$, which passed the requirement of the FDA standard. A single shot of vaccine from Johnson \& Johnson had an average efficacy of $66.9 \%$ (116 positives in the 19,630 vaccinates subjects vs. 348 positives in the 19,691 placebo subjects). Ad5-nCoV from CanSinoBIO had an average efficacy of $65.7 \%(n=30,000)$, which is similar to Ad26.COV2.S. PiCoVacc, which is an inactivated virus vaccine from Sinovac Biotech reported far less effective than the others, around $50 \%$ efficacy (85 positives in the 13,000 vaccinates subjects vs. 167 positives in the 13,000 placebo subjects) in the Brazilian clinical trial. The 2 nano-based mRNA/LNP vaccines (mRNA-1273, BNT162) have reached the positive interim results without doubt in the vaccine safety and efficacy. Interestingly, these will be the first RNA vaccines for human. The application of nanocarriers for the COVID-19 vaccine development has proved its advantages such as accelerating vaccine development, minimal adversed effect (biocompatible, biodegradable, less toxic to the cells), superior vaccine efficacy, and high public trust in vaccine safety. Nevertheless, the duration of vaccine immune response will have to be monitored. It should be noted that the conventional vaccines based on Chimpanzee adenoviral vector (AZD1222) and inactivated virus (PiCoVacc) reached the primary efficacy endpoint but had the vaccine efficacy lower than mRNA/LNP vaccines. The BNT162b2 from PfizerBioNTech was the first mRNA COVID-19 vaccine that was authorized for an emergency use in human in the UK on 2 December 2020, authorized in the USA on 11 December 2020, and authorized by the European Medicines Agency (EMA) in all EU countries on 21 December 2020. The mRNA-1273 from Moderna was the second mRNA COVID-19 that was authorized by the U.S. Food and Drug Administration on December 18, 2020 .

Nevertheless, the rapid mutation of SARS-CoV-2 strain in South Africa (B.1.351), UK (B.1.1.7), Brazil (P.1), and USA (CAL.20C) delayed neutralization antibodies and decreased the vaccine efficacy to prevent the COVID-19 including the individual whom vaccinated with the mRNA vaccine from Pfizer and Moderna, subunit proteins NVX-CoV2373, and viral-based vaccine ChAdOx1, Ad26.COV2.S [138, 292, 293, 430]. The comparative study of the third doses of vaccine against SARS-CoV2 in the transplant recipients showed that the patients who received the boost doses mRNA vaccine from Moderna had the highest antibody titers [431]. In the responses to the variant outbreak, the mRNA vaccine from Moderna which modified in the mRNA antigens to prevent B.1.351 strain has been tested in the clinical trial (NCT04785144). Various platforms of COVID-19 vaccine are beneficial for the consumers in terms of choice for selection, cost, and acceptable adverse effects after vaccinated.

\section{Conclusions}

The vaccines for COVID-19 remain a critical issue. Nanotechnology presents promising strategies for improving the immunogenicity of a vaccine antigen. Numerous vaccines and biodegradable nanoparticle-based delivery vehicles are being evaluated in clinical trials. Within 63 days of genomic sequence of SARS-CoV-2 donated in GenBank, the first nanovaccine candidate entered into the clinical trial Phase I. Today, the scientific community is waiting for Phase III clinical efficacy data. However, there is still plenty of room for further enhancement of COVID-19 vaccines. As shown in the immune-enhanced strategies, the format and uptake of immunogens into dendritic cells are critical parameters for stimulus immunity. Moreover, the vaccine combination with adjuvants can enhance the humoral and cellular immune responses. An ideal candidate COVID-19 vaccine should be a single-dose vaccination, resulting in a long-term and broad immune protection for variant SARS-CoV-2, stable vaccine at room temperature and ability to administer through a noninvasive route. Challenges for nanomaterial-based vaccines that limit the clinical transformation are as follows: (1) design of antigens, which is important for inducing immune responses. The best design of RNA encoded antigens with increased stability and in vivo translation will lead to improved vaccine efficacy; (2) design of carriers, which is important to achieve the target cells and increase the time for storage. Different lipid nanoparticle formulation has different clinical outcomes. For example, the BNT162 vaccine must keep at $-70{ }^{\circ} \mathrm{C}$, while mRNA- 1273 vaccine could be kept at $-20{ }^{\circ} \mathrm{C}$ up to 6 months; (3) selection of appropriate animal models for vaccine testing. SARS-CoV-2 cannot infect the wild type of mice and requires special mice and a special strain of SARS-CoV-2. Immune responses to properties of nanomaterials should be considered in the planning of pre-clinical stage evaluation [432-434]. A promising vaccine from the efficacy reported of Phase 3 clinical trial is mRNA/LNP. The mRNA/LNP vaccines (mRNA-1273, BNT162) showed a high safety profile with superior vaccine efficacy. However, a drawback of mRNA/LNP vaccines is the cold chain limitation, which requires expensive equipment for storage $\left(-70\right.$ or $\left.-20^{\circ} \mathrm{C}\right)$ and requires two doses administered to boost the immunogenicity. In contrast, the adenoviral based vaccine could be kept in the $2-8{ }^{\circ} \mathrm{C}$ refrigerator and requires only single dose vaccination. Nevertheless, the viralbased vector previously shows the risk of getting public trust (AZD1222 and Ad26.COV2.S) and the experiments in Phase 3 are still on-going. For the next generation of immune-enhanced COVID-19 vaccine, self-assembled macromolecules (phage, protein-based platform) are attractive nanomaterial. The phagebased vaccine can enhance immune responses by phage display technology. The virus-like particle is a protein-based platform, which mimics the overall structure of SARS-CoV-2 particles without infectious genomic RNA. It is very safe and adjustable. Further improvements in the next generation nanoparticle-based COVID-19 vaccine include: (1) design for match variants strain including wildtype (D614), mutated (G614) that become a worldwide dominance, and further prediction of virus strains by computational modeling $[435,436]$, resulting in broad protection of variant SARS-CoV-2. (2) Single dose vaccination with minimum dose exposure of antigens. Nanoparticle-based vaccine targeting APCs delivery of the self-amplifying RNA or pDNA could lower administered dose, give high-level transient expression proteins, and elicite robust neutralizing antibody. The low amount requirement of nucleic acid-based antigens also saves costs of large scale production of vaccine [437]. (3) Stable vaccines at room temperature and ability to be administered through a noninvasive route. Nanoparticle-based formulations could offer diminish cold-chain for storage and ease of transportation such as dry-powder VLPs suitable for nasal delivery [438], and gold nanoparticle encapsulated $\mathrm{pDNA}$, and protein for skin vaccination $[326,439]$. Several nanomaterials have been synthesized as antigen carriers with ligands for specific receptors, or stimuli responsive compounds on the surface, expecting to be more efficient than the conventional vaccines. In addition, these nanoparticles can efficiently deliver antigens due to their nanoscale size, chemical properties on their surface, and ability to protect the antigens along with adjuvants. However, the cost of vaccine and public trust in vaccine safety are two of the key factors for the success of vaccination.

\section{Acknowledgments}

This work was supported by OCSC Royal Thai Government- 
UCAS Scholarship under research collaboration between National Nanotechnology Center (NANOTEC), Thailand, and National Center for Nanoscience and Technology, China (No. P1852764). This work was also supported by the National Natural Science Foundation of China (NSFC) key projects (Nos. 31630027 and 32030060), NSFC international collaboration key project (No. 51861135103), and NSFC-German Research Foundation (DFG) project (No. 31761133013). The authors also appreciate the support by "the Beijing-Tianjin-Hebei Basic Research Cooperation Project" (No. 19JCZDJC64100), and National Key Research \& Development Program of China (No. 2018YFE0117800). The authors are grateful for Prof. Dr. S. Seraphin at the Professional Authorship Center, Thailand National Science, and Technology Development Agency (NSTDA) for fruitful discussions on the manuscript preparation.

\section{References}

[1] Zhang, L.; Wang, W.; Wang, S. X. Effect of vaccine administration modality on immunogenicity and efficacy. Expert Rev. Vaccines 2015, 14, 1509-1523.

[2] World Health Organization. Temperature sensitivity of vaccines. Geneva: World Health Organization, 2006.

[3] Lemiale, F.; Kong, W. P.; Akyürek, L. M.; Ling, X.; Huang, Y.; Chakrabarti, B. K.; Eckhaus, M.; Nabel, G. J. Enhanced mucosal immunoglobulin a response of intranasal adenoviral vector human immunodeficiency virus vaccine and localization in the central nervous system. J. Virol. 2003, 77, 10078-10087.

[4] Bregu, M.; Draper, S. J.; Hill, A. V. S.; Greenwood, B. M. Accelerating vaccine development and deployment: Report of a royal society satellite meeting. Philos. Trans. Roy. Soc. Lond B Biol. Sci. 2011, 366, 2841-2849.

[5] Deming, M. E.; Michael, N. L.; Robb, M.; Cohen, M. S.; Neuzil, K. M. Accelerating development of SARS-CoV-2 vaccines-the role for controlled human infection models. N. Engl. J. Med. 2020, 383, e63.

[6] Krammer, F. SARS-CoV-2 vaccines in development. Nature 2020, 586, 516-527.

[7] Nguyen, L. C.; Bakerlee, C. W.; McKelvey, T. G.; Rose, S. M.; Norman, A. J.; Joseph, N.; Manheim, D.; McLaren, M. R.; Jiang, S.; Barnes, C. F. et al. Evaluating use cases for human challenge trials in accelerating SARS-CoV-2 vaccine development. Clin. Infect. Dis. 2021, 72, 710-715.

[8] Torchilin, V. P. Recent advances with liposomes as pharmaceutical carriers. Nat. Rev. Drug Discov. 2005, 4, 145-160.

[9] Tang, X. L.; Wu, C. C.; Li, X.; Song, Y. H.; Yao, X. M.; Wu, X. K.; Duan, Y. G.; Zhang, H.; Wang, Y. R.; Qian, Z. H. et al. On the origin and continuing evolution of SARS-CoV-2. Natl. Sci. Rev. 2020, 7, 1012-1023.

[10] Wu, F.; Zhao, S.; Yu, B.; Chen, Y. M.; Wang, W.; Song, Z. G.; Hu, Y.; Tao, Z. W.; Tian, J. H.; Pei, Y. Y. et al. A new coronavirus associated with human respiratory disease in China. Nature 2020, 579, 265-269.

[11] Belouzard, S.; Millet, J. K.; Licitra, B. N.; Whittaker, G. R. Mechanisms of coronavirus cell entry mediated by the viral spike protein. Viruses 2012, 4, 1011-1033.

[12] Andersen, K. G.; Rambaut, A.; Lipkin, W. I.; Holmes, E. C.; Garry, R. F. The proximal origin of SARS-CoV-2. Nat. Med. 2020, 26, 450-452.

[13] Konno, Y.; Kimura, I.; Uriu, K.; Fukushi, M.; Irie, T.; Koyanagi, Y.; Sauter, D.; Gifford, R. J.; USFQ-COVID19 Consortium; Nakagawa, S. et al. SARS-CoV-2 ORF3b is a potent interferon antagonist whose activity is increased by a naturally occurring elongation variant. Cell Rep. 2020, 32, 108185.

[14] Hadjadj, J.; Yatim, N.; Barnabei, L.; Corneau, A.; Boussier, J.; Smith, N.; Péré, H.; Charbit, B.; Bondet, V.; Chenevier-Gobeaux, C. et al. Impaired type I interferon activity and inflammatory responses in severe COVID-19 patients. Science 2020, 369, 718-724.
[15] Ivashkiv, L. B.; Donlin, L. T. Regulation of type I interferon responses. Nat. Rev. Immunol. 2014, 14, 36-49.

[16] Park, A.; Iwasaki, A. Type I and type III interferons-induction, signaling, evasion, and application to combat COVID-19. Cell Host Microbe 2020, 27, 870-878.

[17] Chan, J. F.; Kok, K. H.; Zhu, Z.; Chu, H.; To, K. K. W.; Yuan, S. F.; Yuen, K. Y. Genomic characterization of the 2019 novel humanpathogenic coronavirus isolated from a patient with atypical pneumonia after visiting Wuhan. Emerg. Microbes Infect. 2020, 9, 221-236.

[18] Muth, D.; Corman, V. M.; Roth, H.; Binger, T.; Dijkman, R.; Gottula, L. T.; Gloza-Rausch, F.; Balboni, A.; Battilani, M.; Rihtarič, D. et al. Attenuation of replication by a 29 nucleotide deletion in SARS-coronavirus acquired during the early stages of human-to-human transmission. Sci. Rep. 2018, 8, 15177.

[19] Su, Y. C. F.; Anderson, D. E.; Young, B. E.; Linster, M.; Zhu, F.; Jayakumar, J.; Zhuang, Y.; Kalimuddin, S.; Low, J. G. H.; Tan, C. W. et al. Discovery and Genomic Characterization of a 382Nucleotide Deletion in ORF7b and ORF8 during the Early Evolution of SARS-CoV-2. mBio 2020, 11, e01610-e01620.

[20] Young, B. E.; Fong, S. W.; Chan, Y. H.; Mak, T. M.; Ang, L. W.; Anderson, D. E.; Lee, C. Y. P.; Amrun, S. N.; Lee, B.; Goh, Y. S. et al. Effects of a major deletion in the SARS-CoV-2 genome on the severity of infection and the inflammatory response: An observational cohort study. Lancet 2020, 396, 603-611.

[21] Kim, D.; Lee, J. Y.; Yang, J. S.; Kim, J. W.; Kim, V. N.; Chang, H. The architecture of SARS-CoV-2 transcriptome. Cell 2020, 181, 914-921.e10.

[22] Bojkova, D.; Klann, K.; Koch, B.; Widera, M.; Krause, D.; Ciesek, S.; Cinatl, J.; Münch, C. Proteomics of SARS-CoV-2-infected host cells reveals therapy targets. Nature 2020, 583, 469-472.

[23] Davidson, A. D.; Williamson, M. K.; Lewis, S.; Shoemark, D.; Carroll, M. W.; Heesom, K. J.; Zambon, M.; Ellis, J.; Lewis, P. A.; Hiscox, J. A. et al. Characterisation of the transcriptome and proteome of SARS-CoV-2 reveals a cell passage induced in-frame deletion of the furin-like cleavage site from the spike glycoprotein. Genome Med. 2020, 12, 68.

[24] Li, M. Y.; Li, L.; Zhang, Y.; Wang, X. S. Expression of the SARS$\mathrm{CoV}-2$ cell receptor gene $A C E 2$ in a wide variety of human tissues. Infect. Dis. Poverty 2020, 9, 45.

[25] Hoffmann, M.; Kleine-Weber, H.; Pöhlmann, S. A multibasic cleavage site in the spike protein of SARS-CoV-2 is essential for infection of human lung cells. Mol. Cell 2020, 78, 779-784.e5.

[26] Sawicki, S. G.; Sawicki, D. L.; Siddell, S. G. A contemporary view of coronavirus transcription. J. Virol. 2007, 81, 20-29.

[27] Snijder, E. J.; van der Meer, Y.; Zevenhoven-Dobbe, J.; Onderwater, J. J. M.; van der Meulen, J.; Koerten, H. K.; Mommaas, A. M. Ultrastructure and origin of membrane vesicles associated with the severe acute respiratory syndrome coronavirus replication complex. J. Virol. 2006, 80, 5927-5940.

[28] de Haan, C. A. M.; Rottier, P. J. M. Molecular interactions in the assembly of coronaviruses. Adv. Virus Res. 2005, 64, 165-230.

[29] Raamsman, M. J. B.; Locker, J. K.; de Hooge, A.; de Vries, A. A. F.; Griffiths, G.; Vennema, H.; Rottier, P. J. M. Characterization of the coronavirus mouse hepatitis virus strain A59 small membrane protein E. J. Virol. 2000, 74, 2333-2342.

[30] Wu, C. R.; Zheng, M. Z.; Yang, Y. Y.; Gu, X. X.; Yang, K. Y.; Li, M. X.; Liu, Y.; Zhang, Q. Z.; Zhang, P.; Wang, Y. L. et al. Furin: A potential therapeutic target for COVID-19. iScience 2020, 23, 101642.

[31] Daly, J. L.; Simonetti, B.; Klein, K.; Chen, K. E.; Williamson, M. K.; Antón-Plágaro, C.; Shoemark, D. K.; Simón-Gracia, L.; Bauer, M.; Hollandi, R. et al. Neuropilin-1 is a host factor for SARS-CoV2 infection. Science 2020, 370, 861-865.

[32] Teesalu, T.; Sugahara, K. N.; Kotamraju, V. R.; Ruoslahti, E. C-end rule peptides mediate neuropilin-1-dependent cell, vascular, and tissue penetration. Proc. Natl. Acad. Sci. USA 2009, 106, 16157-16162.

[33] Guo, H. F.; Vander Kooi, C. W. Neuropilin functions as an essential cell surface receptor. J. Biol. Chem. 2015, 290, 
$29120-29126$.

[34] Parker, M. W.; Guo, H. F.; Li, X. B.; Linkugel, A. D.; Vander Kooi, C. W. Function of members of the neuropilin family as essential pleiotropic cell surface receptors. Biochemistry 2012, 51, 9437-9446.

[35] De Winter, F.; Holtmaat, A. J. G. D.; Verhaagen, J. Neuropilin and class 3 semaphorins in nervous system regeneration. Adv. Exp. Med. Biol. 2002, 515, 115-139.

[36] Roy, S.; Bag, A. K.; Singh, R. K.; Talmadge, J. E.; Batra, S. K.; Datta, K. Multifaceted role of neuropilins in the immune system: Potential targets for immunotherapy. Front. Immunol. 2017, 8, 1228.

[37] Kielian, M. Enhancing host cell infection by SARS-CoV-2. Science 2020, 370, 765-766.

[38] Cantuti-Castelvetri, L.; Ojha, R.; Pedro, L. D.; Djannatian, M.; Franz, J.; Kuivanen, S.; van der Meer, F.; Kallio, K.; Kaya, T.; Anastasina, M. et al. Neuropilin-1 facilitates SARS-CoV-2 cell entry and infectivity. Science 2020, 370, 856-860.

[39] Cheng, Y. W.; Chao, T. L.; Li, C. L.; Chiu, M. F.; Kao, H. C.; Wang, S. H.; Pang, Y. H.; Lin, C. H.; Tsai, Y. M.; Lee, W. H. et al. Furin inhibitors block SARS-CoV-2 spike protein cleavage to suppress virus production and cytopathic effects. Cell Rep. 2020, 33,108254 .

[40] Hoffmann, M.; Kleine-Weber, H.; Schroeder, S.; Krüger, N.; Herrler, T.; Erichsen, S.; Schiergens, T. S.; Herrler, G.; Wu, N. H.; Nitsche, A. et al. SARS-CoV-2 cell entry depends on ACE2 and TMPRSS2 and is blocked by a clinically proven protease inhibitor. Cell 2020, 181, 271-280.e8.

[41] Heinrich, M. A.; Martina, B.; Prakash, J. Nanomedicine strategies to target coronavirus. Nano Today 2020, 35, 100961.

[42] Xia, S.; Liu, M. Q.; Wang, C.; Xu, W.; Lan, Q. S.; Feng, S. L.; Qi, F. F.; Bao, L. L.; Du, L. Y.; Liu, S. W. et al. Inhibition of SARSCoV-2 (previously 2019-nCoV) infection by a highly potent pancoronavirus fusion inhibitor targeting its spike protein that harbors a high capacity to mediate membrane fusion. Cell Res. 2020, 30, 343-355.

[43] Chan, J. F. W.; Yuan, S. F.; Kok, K. H.; To, K. K. W.; Chu, H.; Yang, J.; Xing, F. F.; Liu, J. L.; Yip, C. C. Y.; Poon, R. W. S. et al. A familial cluster of pneumonia associated with the 2019 novel coronavirus indicating person-to-person transmission: A study of a family cluster. Lancet 2020, 395, 514-523.

[44] Fennelly, K. P. Particle sizes of infectious aerosols: Implications for infection control. Lancet Respir. Med. 2020, 8, 914-924.

[45] Lednicky, J. A.; Lauzardo, M.; Fan, Z. H.; Jutla, A.; Tilly, T. B.; Gangwar, M.; Usmani, M.; Shankar, S. N.; Mohamed, K.; EigurenFernandez, A. et al. Viable SARS-CoV-2 in the air of a hospital room with COVID-19 patients. Int. J. Infect. Dis. 2020, 100, 476-482.

[46] Setti, L.; Passarini, F.; De Gennaro, G.; Barbieri, P.; Perrone, M. G.; Borelli, M.; Palmisani, J.; Di Gilio, A.; Piscitelli, P.; Miani, A. Airborne transmission route of COVID-19: Why 2 meters/ 6 feet of inter-personal distance could not be enough. Int. J. Environ. Res. Public Health 2020, 17, 2932.

[47] Fiegel, J.; Clarke, R.; Edwards, D. A. Airborne infectious disease and the suppression of pulmonary bioaerosols. Drug Discov. Today 2006, 11, 51-57.

[48] Thomas, R. J. Particle size and pathogenicity in the respiratory tract. Virulence 2013, 4, 847-858.

[49] van Doremalen, N.; Bushmaker, T.; Morris, D. H.; Holbrook, M. G.; Gamble, A.; Williamson, B. N.; Tamin, A.; Harcourt, J. L.; Thornburg, N. J.; Gerber, S. I. et al. Aerosol and surface stability of SARS-CoV-2 as compared with SARS-CoV-1. N. Engl. J. Med. 2020, 382, 1564-1567.

[50] Aboubakr, H. A.; Sharafeldin, T. A.; Goyal, S. M. Stability of SARS-CoV-2 and other coronaviruses in the environment and on common touch surfaces and the influence of climatic conditions: A review. Transbound. Emerg. Dis. 2021, 68, 296-312.

[51] Chia, P. Y.; Coleman, K. K.; Tan, Y. K.; Ong, S. W. X.; Gum, M.; Lau, S. K.; Lim, X. F.; Lim, A. S.; Sutjipto, S.; Lee, P. H. et al. Detection of air and surface contamination by SARS-CoV-2 in hospital rooms of infected patients. Nat. Commun. 2020, 11, 2800.
[52] Santarpia, J. L.; Rivera, D. N.; Herrera, V. L.; Morwitzer, M. J.; Creager, H. M.; Santarpia, G. W.; Crown, K. K.; Brett-Major, D. M.; Schnaubelt, E. R.; Broadhurst, M. J. et al. Aerosol and surface contamination of SARS-CoV-2 observed in quarantine and isolation care. Sci. Rep. 2020, 10, 12732.

[53] Buonanno, M.; Welch, D.; Shuryak, I.; Brenner, D. J. Far-UVC light $(222 \mathrm{~nm})$ efficiently and safely inactivates airborne human coronaviruses. Sci. Rep. 2020, 10, 10285.

[54] Pastorino, B.; Touret, F.; Gilles, M.; de Lamballerie, X.; Charrel, R. N. Heat inactivation of different types of SARS-CoV-2 samples: What protocols for biosafety, molecular detection and serological diagnostics? Viruses 2020, 12, 735.

[55] Anderson, D. E.; Sivalingam, V.; Kang, A. E. Z.; Ananthanarayanan, A.; Arumugam, H.; Jenkins, T. M.; Hadjiat, Y.; Eggers, M. Povidone-iodine demonstrates rapid in vitro virucidal activity against SARS-CoV-2, the virus causing COVID-19 disease. Infect. Dis. Ther. 2020, 9, 669-675.

[56] Kampf, G. Potential role of inanimate surfaces for the spread of coronaviruses and their inactivation with disinfectant agents. Infect. Prev. Pract. 2020, 2, 100044.

[57] Huang, C. L.; Wang, Y. M.; Li, X. W.; Ren, L. L.; Zhao, J. P.; Hu, Y.; Zhang, L.; Fan, G. H.; Xu, J. Y.; Gu, X. Y. et al. Clinical features of patients infected with 2019 novel coronavirus in Wuhan, China. Lancet 2020, 395, 497-506.

[58] Qiu, H. Y.; Wu, J. H.; Hong, L.; Luo, Y. L.; Song, Q. F.; Chen, D. Clinical and epidemiological features of 36 children with coronavirus disease 2019 (COVID-19) in Zhejiang, China: An observational cohort study. Lancet Infect. Dis. 2020, 20, 689-696.

[59] Du, R. H.; Liang, L. R.; Yang, C. Q.; Wang, W.; Cao, T. Z.; Li, M.; Guo, G. Y.; Du, J.; Zheng, C. L.; Zhu, Q. et al. Predictors of mortality for patients with COVID-19 pneumonia caused by SARSCoV-2: A prospective cohort study. Eur. Respir. J. 2020, 55, 2000524.

[60] Agyeman, A. A.; Chin, K. L.; Landersdorfer, C. B.; Liew, D.; OforiAsenso, R. Smell and taste dysfunction in patients with COVID-19: A systematic review and meta-analysis. Mayo Clin. Proc. 2020, 95, 1621-1631.

[61] Klopfenstein, T.; Kadiane-Oussou, N. J.; Toko, L.; Royer, P. Y.; Lepiller, Q.; Gendrin, V.; Zayet, S. Features of anosmia in COVID19. Med. Mal. Infect. 2020, 50, 436-439.

[62] Vaira, L. A.; Salzano, G.; Deiana, G.; De Riu, G. Anosmia and ageusia: Common findings in COVID-19 patients. Laryngoscope 2020, 130, 1787.

[63] Al-Zaidi, H. M. H.; Badr, H. M. Incidence and recovery of smell and taste dysfunction in COVID-19 positive patients. Egypt. J. Otolaryngol. 2020, 36, 47.

[64] Lechien, J. R.; Chiesa-Estomba, C. M.; De Siati, D. R.; Horoi, M.; Le Bon, S. D.; Rodriguez, A.; Dequanter, D.; Blecic, S.; El Afia, F.; Distinguin, L. et al. Olfactory and gustatory dysfunctions as a clinical presentation of mild-to-moderate forms of the coronavirus disease (COVID-19): A multicenter European study. Eur. Arch. Oto-Rhino-Laryngol. 2020, 277, 2251-2261.

[65] Guan, W. J.; Ni, Z. Y.; Hu, Y.; Liang, W. H.; Ou, C. Q.; He, J. X.; Liu, L.; Shan, H.; Lei, C. L.; Hui, D. S. C. et al. Clinical characteristics of coronavirus disease 2019 in China. N. Engl. J. Med. 2020, 382, 1708-1720.

[66] Pung, R.; Chiew, C. J.; Young, B. E.; Chin, S.; Chen, M. I. C.; Clapham, H. E.; Cook, A. R.; Maurer-Stroh, S.; Toh, M. P. H. S.; Poh, C. et al. Investigation of three clusters of COVID-19 in Singapore: Implications for surveillance and response measures. Lancet 2020, 395, 1039-1046.

[67] Yan, Y.; Chang, L.; Wang, L. N. Laboratory testing of SARS-CoV, MERS-CoV, and SARS-CoV-2 (2019-nCoV): Current status, challenges, and countermeasures. Rev. Med. Virol. 2020, 30, e2106.

[68] Zhou, H.; Chen, X.; Hu, T.; Li, J.; Song, H.; Liu, Y. R.; Wang, P. H.; Liu, D.; Yang, J.; Holmes, E. C. et al. A novel bat coronavirus closely related to SARS-CoV-2 contains natural insertions at the $\mathrm{S} 1 / \mathrm{S} 2$ cleavage site of the spike protein. Curr. Biol. 2020, 30, 2196-2206.e3.

[69] Zhao, J. J.; Yuan, Q.; Wang, H. Y.; Liu, W.; Liao, X. J.; Su, Y. Y.; Wang, X.; Yuan, J.; Li, T. D.; Li, J. X. et al. Antibody responses to 
SARS-CoV-2 in patients with novel coronavirus disease 2019. Clin. Infect. Dis. 2020, 71, 2027-2034.

[70] Li, Z. T.; Yi, Y. X.; Luo, X. M.; Xiong, N.; Liu, Y.; Li, S. Q.; Sun, R. L.; Wang, Y. Q.; Hu, B. C.; Chen, W. et al. Development and clinical application of a rapid IgM-IgG combined antibody test for SARS-CoV-2 infection diagnosis. J. Med. Virol. 2020, 92, $1518-1524$

[71] Xiao, A. T.; Gao, C.; Zhang, S. Profile of specific antibodies to SARS-CoV-2: The first report. J. Infect. 2020, 81, 147-178.

[72] Yu, H. Q.; Sun, B. Q.; Fang, Z. F.; Zhao, J. C.; Liu, X. Y.; Li, Y. M.; Sun, X. Z.; Liang, H. F.; Zhong, B.; Huang, Z. F. et al. Distinct features of SARS-CoV-2-specific IgA response in COVID-19 patients. Eur. Respir. J. 2020, 56, 2001526

[73] Zhou, P.; Yang, X. L.; Wang, X. G.; Hu, B.; Zhang, L.; Zhang, W.; Si, H. R.; Zhu, Y.; Li, B.; Huang, C. L. et al. A pneumonia outbreak associated with a new coronavirus of probable bat origin. Nature 2020, 579, 270-273.

[74] Katze, M. G.; He, Y. P.; Gale, M. Jr. Viruses and interferon: A fight for supremacy. Nat. Rev. Immunol. 2002, 2, 675-687.

[75] Payne, S. Immunity and resistance to viruses. In Viruses: From Understanding to Investigation. Payne, S., Ed.; Academic Press: London, 2017; pp 61-71.

[76] Stanifer, M. L.; Kee, C.; Cortese, M.; Zumaran, C. M.; Triana, S.; Mukenhirn, M.; Kraeusslich, H. G.; Alexandrov, T.; Bartenschlager, R.; Boulant, S. Critical role of type III interferon in controlling SARS-CoV-2 infection in human intestinal epithelial cells. Cell Rep. 2020, 32, 107863.

[77] Broggi, A.; Ghosh, S.; Sposito, B.; Spreafico, R.; Balzarini, F.; Lo Cascio, A.; Clementi, N.; De Santis, M.; Mancini, N.; Granucci, F. et al. Type III interferons disrupt the lung epithelial barrier upon viral recognition. Science 2020, 369, 706-712.

[78] Blanco-Melo, D.; Nilsson-Payant, B. E.; Liu, W. C.; Uhl, S.; Hoagland, D.; Møller, R.; Jordan, T. X.; Oishi, K.; Panis, M.; Sachs, D. et al. Imbalanced host response to SARS-CoV-2 drives development of COVID-19. Cell 2020, 181, 1036-1045.e9.

[79] Pedersen, S. F.; Ho, Y. C. SARS-CoV-2: A storm is raging. J. Clin. Invest. 2020, 130, 2202-2205.

[80] Mantlo, E.; Bukreyeva, N.; Maruyama, J.; Paessler, S.; Huang, C. Antiviral activities of type I interferons to SARS-CoV-2 infection. Antiviral Res. 2020, 179, 104811.

[81] Wherry, E. J.; Masopust, D. Adaptive immunity: Neutralizing, eliminating, and remembering for the next time. In Viral Pathogenesis: From Basics to Systems Biology. Katze, M. G.; Korth, M. J.; Law, G. L.; Nathanson, N., Eds.; Academic Press: Boston, 2016; pp 57-69.

[82] Weiskopf, D.; Schmitz, K. S.; Raadsen, M. P.; Grifoni, A.; Okba, N. M. A.; Endeman, H.; van den Akker, J. P. C.; Molenkamp, R.; Koopmans, M. P. G.; van Gorp, E. C. M. et al. Phenotype and kinetics of SARS-CoV-2-specific T cells in COVID-19 patients with acute respiratory distress syndrome. Sci. Immunol. 2020, 5, eabd2071.

[83] Grifoni, A.; Weiskopf, D.; Ramirez, S. I.; Mateus, J.; Dan, J. M.; Moderbacher, C. R.; Rawlings, S. A.; Sutherland, A.; Premkumar, L.; Jadi, R. S. et al. Targets of T cell responses to SARS-CoV-2 coronavirus in humans with COVID-19 disease and unexposed individuals. Cell 2020, 181, 1489-1501,e15.

[84] Chu, D. K. W.; Pan, Y.; Cheng, S. M. S.; Hui, K. P. Y.; Krishnan, P.; Liu, Y. Z.; Ng, D. Y. M.; Wan, C. K. C.; Yang, P.; Wang, Q. Y. et al. Molecular diagnosis of a novel coronavirus (2019-nCoV) causing an outbreak of pneumonia. Clin. Chem. 2020, 66, 549-555.

[85] Wang, D. W.; Hu, B.; Hu, C.; Zhu, F. F.; Liu, X.; Zhang, J.; Wang, B. B.; Xiang, H.; Cheng, Z. S.; Xiong, Y. et al. Clinical characteristics of 138 hospitalized patients with 2019 novel coronavirus-infected pneumonia in Wuhan, China. JAMA 2020, 323, 1061-1069.

[86] Yan, C.; Cui, J.; Huang, L.; Du, B.; Chen, L.; Xue, G.; Li, S.; Zhang, W.; Zhao, L.; Sun, Y. et al. Rapid and visual detection of 2019 novel coronavirus (SARS-CoV-2) by a reverse transcription loop-mediated isothermal amplification assay. Clin. Microbiol. Infect. 2020, 26, 773-779.
[87] Patchsung, M.; Jantarug, K.; Pattama, A.; Aphicho, K.; Suraritdechachai, S.; Meesawat, P.; Sappakhaw, K.; Leelahakorn, N.; Ruenkam, T.; Wongsatit, T. et al. Clinical validation of a Cas13based assay for the detection of SARS-CoV-2 RNA. Nat. Biomed. Eng. 2020, 4, 1140-1149.

[88] Kim, C.; Ahmed, J. A.; Eidex, R. B.; Nyoka, R.; Waiboci, L. W.; Erdman, D.; Tepo, A.; Mahamud, A. S.; Kabura, W.; Nguhi, M. et al. Comparison of nasopharyngeal and oropharyngeal swabs for the diagnosis of eight respiratory viruses by real-time reverse transcription-PCR assays. PLoS One 2011, 6, e21610.

[89] Vashist, S. K. In vitro diagnostic assays for COVID-19: Recent advances and emerging trends. Diagnostics 2020, 10, 202.

[90] Liu, W. B.; Liu, L.; Kou, G. M.; Zheng, Y. Q.; Ding, Y. J.; Ni, W. X.; Wang, Q. S.; Tan, L.; Wu, W. L.; Tang, S. et al. Evaluation of nucleocapsid and spike protein-based enzyme-linked immunosorbent assays for detecting antibodies against SARS-CoV2. J. Clin. Microbiol. 2020, 58, e00461-20.

[91] Wölfel, R.; Corman, V. M.; Guggemos, W.; Seilmaier, M.; Zange, S.; Müller, M. A.; Niemeyer, D.; Jones, T. C.; Vollmar, P.; Rothe, C. et al. Virological assessment of hospitalized patients with COVID-2019. Nature 2020, 581, 465-469.

[92] Zhang, W.; Du, R. H.; Li, B.; Zheng, X. S.; Yang, X. L.; Hu, B. Wang, Y. Y.; Xiao, G. F.; Yan, B.; Shi, Z. L. et al. Molecular and serological investigation of 2019-nCoV infected patients: Implication of multiple shedding routes. Emerg. Microbes Infect. 2020, 9, 386-389.

[93] Li, Y.; Xia, L. M. Coronavirus disease 2019 (COVID-19): Role of chest $\mathrm{CT}$ in diagnosis and management. Am. J. Roentgenol. 2020, $214,1280-1286$.

[94] Ng, M. Y.; Lee, E. Y. P.; Yang, J.; Yang, F. F.; Li, X.; Wang, H. X.; Lui, M. M. S.; Lo, C. S. Y.; Leung, B.; Khong, P. L. et al. Imaging profile of the COVID-19 infection: Radiologic findings and literature review. Radiol. Cardiothorac. Imaging 2020, 2 , e200034.

[95] Burrell, C. J.; Howard, C. R.; Murphy, F. A. Vaccines and vaccination. In Fenner and White's Medical Virology. Burrell, C. J. Howard, C. R.; Murphy, F. A., Eds.; Academic Press: London, 2017; pp 155-167.

[96] Zhou, Z. P.; Dang. Sci. USA 2016, 113, E6117-E6125.

[97] Mueller, S.; Papamichail, D.; Coleman, J. R.; Skiena, S.; Wimmer, E. Reduction of the rate of poliovirus protein synthesis through large-scale codon deoptimization causes attenuation of viral virulence by lowering specific infectivity. J. Virol. 2006, 80, 9687-9696.

[98] Nogales, A.; Baker, S. F.; Ortiz-Riaño, E.; Dewhurst, S.; Topham, D. J.; Martínez-Sobrido, L. Influenza a virus attenuation by codon deoptimization of the NS gene for vaccine development. J. Virol. 2014, $88,10525-10540$

[99] Dilucca, M.; Forcelloni, S.; Georgakilas, A. G.; Giansanti, A.; Pavlopoulou, A. Codon usage and phenotypic divergences of SARSCoV-2 genes. Viruses 2020, 12, 498.

[100] Tort, F. L.; Castells, M.; Cristina, J. A comprehensive analysis of genome composition and codon usage patterns of emerging coronaviruses. Virus Res. 2020, 283, 197976.

[101] Dudek, T.; Knipe, D. M. Replication-defective viruses as vaccines and vaccine vectors. Virology 2006, 344, 230-239.

[102] Lau, S. Y.; Wang, P.; Mok, B. W. Y.; Zhang, A. J.; Chu, H.; Lee, A. C. Y.; Deng, S. F.; Chen, P.; Chan, K. H.; Song, W. J. et al. Attenuated SARS-CoV-2 variants with deletions at the S1/S2 junction. Emerg. Microbes Infect. 2020, 9, 837-842.

[103] Bull, J. J.; Smithson, M. W.; Nuismer, S. L. Transmissible viral vaccines. Trends Microbiol. 2018, 26, 6-15.

[104] Sanders, B.; Koldijk, M.; Schuitemaker, H. Inactivated viral vaccines. In Vaccine Analysis: Strategies, Principles, and Control. Nunnally, B. K.; Turula, V. E.; Sitrin, R. D., Eds.; Springer: Berlin, Heidelberg, 2015; pp 45-80.

[105] Seo, H. S. Application of radiation technology in vaccines development. Clin. Exp. Vaccine Res. 2015, 4, 145-158.

[106] He, Y. X.; Zhou, Y. S.; Siddiqui, P.; Jiang, S. B. Inactivated SARS$\mathrm{CoV}$ vaccine elicits high titers of spike protein-specific antibodies 
that block receptor binding and virus entry. Biochem. Biophys. Res. Commun. 2004, 325, 445-452.

[107] Gao, Q.; Bao, L. L.; Mao, H. Y.; Wang, L.; Xu, K. W.; Yang, M. N.; Li, Y. J.; Zhu, L.; Wang, N.; Lv, Z. et al. Development of an inactivated vaccine candidate for SARS-CoV-2. Science 2020, 369, 77-81.

[108] Bouard, D.; Alazard-Dany, D.; Cosset, F. L. Viral vectors: From virology to transgene expression. Br. J. Pharmacol. 2009, 157, $153-165$.

[109] Pinschewer, D. D. Virally vectored vaccine delivery: Medical needs, mechanisms, advantages and challenges. Swiss Med. Wkly. 2017, 147, w14465.

[110] Robert-Guroff, M. Replicating and non-replicating viral vectors for vaccine development. Curr. Opin. Biotechnol. 2007, 18, 546-556.

[111] Billeter, M. A.; Naim, H. Y.; Udem, S. A. Reverse genetics of measles virus and resulting multivalent recombinant vaccines: Applications of recombinant measles viruses. Curr. Top. Microbiol. Immunol. 2009, 329, 129-162.

[112] Malczyk, A. H.; Kupke, A.; Prüfer, S.; Scheuplein, V. A.; Hutzler, S.; Kreuz, D.; Beissert, T.; Bauer, S.; Hubich-Rau, S.; Tondera, C. et al. A highly immunogenic and protective middle east respiratory syndrome coronavirus vaccine based on a recombinant measles virus vaccine platform. J. Virol. 2015, 89, 11654-11667.

[113] Escriou, N.; Callendret, B.; Lorin, V.; Combredet, C.; Marianneau, P.; Février, M.; Tangy, F. Protection from SARS coronavirus conferred by live measles vaccine expressing the spike glycoprotein. Virology 2014, 452-453, 32-41.

[114] Liniger, M.; Zuniga, A.; Tamin, A.; Azzouz-Morin, T. N.; Knuchel, M.; Marty, R. R.; Wiegand, M.; Weibel, S.; Kelvin, D.; Rota, P. A. et al. Induction of neutralising antibodies and cellular immune responses against SARS coronavirus by recombinant measles viruses. Vaccine 2008, 26, 2164-2174.

[115] Mura, M.; Ruffié, C.; Combredet, C.; Aliprandini, E.; Formaglio, P.; Chitnis, C. E.; Amino, R.; Tangy, F. Recombinant measles vaccine expressing malaria antigens induces long-term memory and protection in mice. npj Vaccines 2019, 4, 12.

[116] Liniger, M.; Zuniga, A.; Morin, T. N.; Combardiere, B.; Marty, R.; Wiegand, M.; Ilter, O.; Knuchel, M.; Naim, H. Y. Recombinant measles viruses expressing single or multiple antigens of human immunodeficiency virus (HIV-1) induce cellular and humoral immune responses. Vaccine 2009, 27, 3299-3305.

[117] Kapadia, S. U.; Rose, J. K.; Lamirande, E.; Vogel, L.; Subbarao, K.; Roberts, A. Long-term protection from SARS coronavirus infection conferred by a single immunization with an attenuated VSV-based vaccine. Virology 2005, 340, 174-182.

[118] Nicklin, S. A.; Wu, E.; Nemerow, G. R.; Baker, A. H. The influence of adenovirus fiber structure and function on vector development for gene therapy. Mol. Ther. 2005, 12, 384-393.

[119] Charman, M.; Herrmann, C.; Weitzman, M. D. Viral and cellular interactions during adenovirus DNA replication. FEBS Lett. 2019, 593, 3531-3550.

[120] Fessler, S. P.; Young, C. S. H. Control of adenovirus early gene expression during the late phase of infection. J. Virol. 1998, 72, 4049-4056.

[121] Persson, H.; Philipson, L. Regulation of adenovirus gene expression. Curr. Top. Microbiol. Immunol. 1982, 97, 157-203.

[122] Bauer, U.; Flunker, G.; Bruss, K.; Kallwellis, K.; Liebermann, H.; Luettich, T.; Motz, M.; Seidel, W. Detection of antibodies against adenovirus protein IX, fiber, and hexon in human sera by immunoblot assay. J. Clin. Microbiol. 2005, 43, 4426-4433.

[123] Hashimoto, S.; Gonzalez, G.; Harada, S.; Oosako, H.; Hanaoka, N.; Hinokuma, R.; Fujimoto, T. Recombinant type Human mastadenovirus D85 associated with epidemic keratoconjunctivitis since 2015 in Japan. J. Med. Virol. 2018, 90, 881-889.

[124] Kajon, A. E.; Weinberg, J. B.; Spindler, K. R. Adenoviruses. In Reference Module in Biomedical Sciences. Elsevier: Amsterdam, 2019.

[125] Bridge, E.; Ketner, G. Redundant control of adenovirus late gene expression by early region 4. J. Virol. 1989, 63, 631-638.

[126] Rubinchik, S.; Woraratanadharm, J.; Schepp, J.; Dong, J. Y. Improving the transcriptional regulation of genes delivered by adenovirus vectors. Methods Mol. Med. 2003, 76, 167-199.

[127] Bett, A. J.; Prevec, L.; Graham, F. L. Packaging capacity and stability of human adenovirus type 5 vectors. J. Virol. 1993, 67, 5911-5921.

[128] Wold, W. S. M.; Toth, K. Adenovirus vectors for gene therapy, vaccination and cancer gene therapy. Curr. Gene Ther. 2013, 13, 421-433.

[129] Zhu, F. C.; Li, Y. H.; Guan, X. H.; Hou, L. H.; Wang, W. J.; Li, J. X.; Wu, S. P.; Wang, B. S.; Wang, Z.; Wang, L. et al. Safety, tolerability, and immunogenicity of a recombinant adenovirus type5 vectored COVID-19 vaccine: A dose-escalation, open-label, nonrandomised, first-in-human trial. Lancet 2020, 395, 1845-1854.

[130] Ng, P.; Parks, R. J.; Cummings, D. T.; Evelegh, C. M.; Graham, F. L. An enhanced system for construction of adenoviral vectors by the two-plasmid rescue method. Hum. Gene Ther. 2000, 11, 693-699.

[131] Bos, R.; Rutten, L.; van der Lubbe, J. E. M.; Bakkers, M. J. G.; Hardenberg, G.; Wegmann, F.; Zuijdgeest, D.; de Wilde, A. H.; Koornneef, A.; Verwilligen, A. et al. Ad26 vector-based COVID19 vaccine encoding a prefusion-stabilized SARS-CoV-2 Spike immunogen induces potent humoral and cellular immune responses. npj Vaccines 2020, 5, 91.

[132] Abbink, P.; Lemckert, A. A. C.; Ewald, B. A.; Lynch, D. M.; Denholtz, M.; Smits, S.; Holterman, L.; Damen, I.; Vogels, R.; Thorner, A. R. et al. Comparative seroprevalence and immunogenicity of six rare serotype recombinant adenovirus vaccine vectors from subgroups B and D. J. Virol. 2007, 81, 4654-4663.

[133] Yu, J.; Tostanoski, L. H.; Mercado, N. B.; McMahan, K.; Liu, J. Y.; Jacob-Dolan, C.; Chandrashekar, A.; Atyeo, C.; Martinez, D. R.; Anioke, T. et al. Protective efficacy of Ad26.COV2.S against SARS-CoV-2 B.1.351 in macaques. Nature 2021, 596, 423-427.

[134] Tostanoski, L. H.; Wegmann, F.; Martinot, A. J.; Loos, C.; McMahan, K.; Mercado, N. B.; Yu, J. Y.; Chan, C. N.; Bondoc, S.; Starke, C. E. et al. Ad26 vaccine protects against SARS-CoV-2 severe clinical disease in hamsters. Nat. Med. 2020, 26, 1694-1700.

[135] Mercado, N. B.; Zahn, R.; Wegmann, F.; Loos, C.; Chandrashekar, A.; Yu, J. Y.; Liu, J. Y.; Peter, L.; McMahan, K.; Tostanoski, L. H. et al. Single-shot Ad26 vaccine protects against SARS-CoV-2 in rhesus macaques. Nature 2020, 586, 583-588.

[136] Stephenson, K. E.; Le Gars, M.; Sadoff, J.; de Groot, A. M.; Heerwegh, D.; Truyers, C.; Atyeo, C.; Loos, C.; Chandrashekar, A.; McMahan, K. et al. Immunogenicity of the Ad26. COV2. S vaccine for COVID-19. JAMA 2021, 325, 1535-1544.

[137] Sadoff, J.; Le Gars, M.; Shukarev, G.; Heerwegh, D.; Truyers, C.; de Groot, A. M.; Stoop, J.; Tete, S.; Van Damme, W.; LerouxRoels, I. et al. Interim results of a phase 1-2a trial of Ad26. COV2. S Covid-19 vaccine. N. Engl. J. Med. 2021, 384, 1824-1835.

[138] Alter, G.; Yu, J. Y.; Liu, J. Y.; Chandrashekar, A.; Borducchi, E. N.; Tostanoski, L. H.; McMahan, K.; Jacob-Dolan, C.; Martinez, D. R.; Chang, A. Q. et al. Immunogenicity of Ad26.COV2.S vaccine against SARS-CoV-2 variants in humans. Nature 2021, 596, 268-272.

[139] Rux, J. J.; Kuser, P. R.; Burnett, R. M. Structural and phylogenetic analysis of adenovirus hexons by use of high-resolution X-ray crystallographic, molecular modeling, and sequence-based methods. J. Virol. 2003, 77, 9553-9566.

[140] Rogers, N. G.; Basnight, M.; Gibbs Jun, C. J.; Gajdusek, D. C. Latent viruses in chimpanzees with experimental kuru. Nature 1967, 216, 446-449.

[141] Basnight, M. Jr.; Rogers, N. G.; Gibbs, C. J. Jr.; Gajdusek, D. C. Characterization of four new adenovirus serotypes isolated from chimpanzee tissue explants. Am. J. Epidemiol. 1971, 94, 166-171.

[142] Davison, A. J.; Benkö, M.; Harrach, B. Genetic content and evolution of adenoviruses. J. Gen. Virol. 2003, 84, 2895-2908.

[143] Roy, S.; Gao, G. P.; Clawson, D. S.; Vandenberghe, L. H.; Farina, S. F.; Wilson, J. M. Complete nucleotide sequences and genome organization of four chimpanzee adenoviruses. Virology 2004, 324, 361-372.

[144] Farina, S. F.; Gao, G. P.; Xiang, Z. Q.; Rux, J. J.; Burnett, R. M.; Alvira, M. R.; Marsh, J.; Ertl, H. C. J.; Wilson, J. M. Replication- 
defective vector based on a chimpanzee adenovirus. J. Virol. 2001, 75, 11603-11613.

[145] Wang, X.; Xing, M.; Zhang, C.; Yang, Y.; Chi, Y. D.; Tang, X. Y.; Zhang, H. B.; Xiong, S. D.; Yu, L. G.; Zhou, D. M. Neutralizing antibody responses to enterovirus and adenovirus in healthy adults in China. Emerg. Microbes Infect. 2014, 3, 1-6.

[146] Chirmule, N.; Propert, K. J.; Magosin, S. A.; Qian, Y.; Qian, R.; Wilson, J. M. Immune responses to adenovirus and adenoassociated virus in humans. Gene Ther. 1999, 6, 1574-1583.

[147] Xiang, Z. Q.; Li, Y.; Cun, A.; Yang, W.; Ellenberg, S.; Switzer, W. M.; Kalish, M. L.; Ertl, H. C. J. Chimpanzee adenovirus antibodies in humans, sub-Saharan Africa. Emerg. Infect. Dis. 2006, 12, $1596-1599$

[148] Fitzgerald, J. C.; Gao, G. P.; Reyes-Sandoval, A.; Pavlakis, G. N.; Xiang, Z. Q.; Wlazlo, A. P.; Giles-Davis, W.; Wilson, J. M.; Ertl, H. C. J. A simian replication-defective adenoviral recombinant vaccine to HIV-1 gag. J. Immunol. 2003, 170, 1416-1422.

[149] Xiang, Z. Q.; Gao, G. P.; Reyes-Sandoval, A.; Cohen, C. J.; Li, Y.; Bergelson, J. M.; Wilson, J. M.; Ertl, H. C. J. Novel, chimpanzee serotype 68-based adenoviral vaccine carrier for induction of antibodies to a transgene product. J. Virol. 2002, 76, 2667-2675.

[150] Kobinger, G. P.; Feldmann, H.; Zhi, Y.; Schumer, G.; Gao, G. P.; Feldmann, F.; Jones, S.; Wilson, J. M. Chimpanzee adenovirus vaccine protects against Zaire Ebola virus. Virology 2006, 346, 394-401.

[151] Hillis, W. D.; Goodman, R. Serologic classification of chimpanzee adenoviruses by hemagglutination and hemagglutination inhibition. J. Immunol. 1969, 103, 1089-1095.

[152] Dicks, M. D. J.; Spencer, A. J.; Edwards, N. J.; Wadell, G.; Bojang, K.; Gilbert, S. C.; Hill, A. V. S.; Cottingham, M. G. A novel chimpanzee adenovirus vector with low human seroprevalence: Improved systems for vector derivation and comparative immunogenicity. PLoS One 2012, 7, e40385.

[153] van Doremalen, N.; Haddock, E.; Feldmann, F.; Meade-White, K.; Bushmaker, T.; Fischer, R. J.; Okumura, A.; Hanley, P. W.; Saturday, G.; Edwards, N. J. et al. A single dose of ChAdOx1 MERS provides protective immunity in rhesus macaques. $S c i$. $A d v$. 2020, 6, eaba8399.

[154] van Doremalen, N.; Lambe, T.; Spencer, A.; Belij-Rammerstorfer, S.; Purushotham, J. N.; Port, J. R.; Avanzato, V. A.; Bushmaker, T.; Flaxman, A.; Ulaszewska, M. et al. ChAdOx1 nCoV-19 vaccine prevents SARS-CoV-2 pneumonia in rhesus macaques. Nature 2020, 586, 578-582.

[155] Ramasamy, M. N.; Minassian, A. M.; Ewer, K. J.; Flaxman, A. L.; Folegatti, P. M.; Owens, D. R.; Voysey, M.; Aley, P. K.; Angus, B.; Babbage, G. et al. Safety and immunogenicity of ChAdOx1 $\mathrm{nCoV}-19$ vaccine administered in a prime-boost regimen in young and old adults (COV002): A single-blind, randomised, controlled, phase 2/3 trial. Lancet 2021, 396, 1979-1993.

[156] Chaplin, D. D. Overview of the immune response. J. Allergy Clin. Immunol. 2010, 125, S3-S23.

[157] Pollard, A. J.; Bijker, E. M. A guide to vaccinology: From basic principles to new developments. Nat. Rev. Immunol. 2021, 21, 83-100.

[158] Ng, O. W.; Chia, A.; Tan, A. T.; Jadi, R. S.; Leong, H. N.; Bertoletti, A.; Tan, Y. J. Memory T cell responses targeting the SARS coronavirus persist up to 11 years post-infection. Vaccine 2016, 34, 2008-2014.

[159] Kang, S. S.; Yang, M.; Hong, Z. S.; Zhang, L. P.; Huang, Z. X.; Chen, X. X.; He, S. H.; Zhou, Z. L.; Zhou, Z. C.; Chen, Q. Y. et al. Crystal structure of SARS-CoV-2 nucleocapsid protein RNA binding domain reveals potential unique drug targeting sites. Acta Pharm. Sin. B 2020, 10, 1228-1238.

[160] Dutta, N. K.; Mazumdar, K.; Gordy, J. T. The nucleocapsid protein of SARS-CoV-2: A target for vaccine development. J. Virol. 2020, 94, e00647-20.

[161] Aktas, E. Bioinformatics analysis unveils certain mutations implicated in spike structure damage and ligand-binding site of severe acute respiratory syndrome coronavirus 2. Bioinform. Biol. Insights 2021, DOI: 10.1177/11779322211018200.
[162] Chen, H. Z.; Tang, L. L.; Yu, X. L.; Zhou, J.; Chang, Y. F.; Wu, X. Bioinformatics analysis of epitope-based vaccine design against the novel SARS-CoV-2. Infect. Dis. Poverty 2020, 9, 88.

[163] Sun, Q. H.; Radosz, M.; Shen, Y. Q. Challenges in design of translational nanocarriers. J. Control. Release 2012, 164, 156-169.

[164] Sun, Q. H.; Zhou, Z. X.; Qiu, N. S.; Shen, Y. Q. Rational design of cancer nanomedicine: Nanoproperty integration and synchronization. Adv. Mater. 2017, 29, 1606628.

[165] Ganguly, P.; Breen, A.; Pillai, S. C. Toxicity of nanomaterials: Exposure, pathways, assessment, and recent advances. ACS Biomater. Sci. Eng. 2018, 4, 2237-2275.

[166] Sharifi, S.; Behzadi, S.; Laurent, S.; Forrest, M. L.; Stroeve, P.; Mahmoudi, M. Toxicity of nanomaterials. Chem. Soc. Rev. 2012, 41, 2323-2343

[167] Moitra, P.; Alafeef, M.; Dighe, K.; Frieman, M. B.; Pan, D. Selective naked-eye detection of SARS-CoV-2 mediated by N gene targeted antisense oligonucleotide capped plasmonic nanoparticles. ACS Nano 2020, 14, 7617-7627.

[168] Balagna, C.; Perero, S.; Percivalle, E.; Nepita, E. V.; Ferraris, M Virucidal effect against coronavirus SARS-CoV-2 of a silver nanocluster/silica composite sputtered coating. Open Ceram. 2020, 1,100006

[169] Islam, N.; Ferro, V. Recent advances in chitosan-based nanoparticulate pulmonary drug delivery. Nanoscale 2016, 8 , $14341-14358$

[170] Attama, A. A.; Momoh, M. A.; Builders, P. F. Lipid nanoparticulate drug delivery systems: A revolution in dosage form design and development. In Recent Advances in Novel Drug Carrier Systems; Sezer, A. D. Ed.; IntechOpen, 2012.

[171] Schwendener, R. A. Liposomes as vaccine delivery systems: A review of the recent advances. Ther. Adv. Vaccines 2014, 2, 159-182.

[172] Gharbavi, M.; Amani, J.; Kheiri-Manjili, H.; Danafar, H.; Sharafi, A. Niosome: A promising nanocarrier for natural drug delivery through blood-brain barrier. Adv. Pharmacol. Sci. 2018, 2018, 6847971.

[173] Chime, S. A.; Kenechukwu, F. C.; Attama, A. A. NanoemulsionsAdvances in Formulation, Characterization and Applications in Drug Delivery; IntechOpen, 2014.

[174] Bobo, D.; Robinson, K. J.; Islam, J.; Thurecht, K. J.; Corrie, S. R. Nanoparticle-based medicines: A review of FDA-approved materials and clinical trials to date. Pharm. Res. 2016, 33, 2373-2387.

[175] Gabizon, A.; Papahadjopoulos, D. Liposome formulations with prolonged circulation time in blood and enhanced uptake by tumors. Proc. Natl. Acad. Sci. USA 1988, 85, 6949-6953.

[176] Bal, S. M.; Hortensius, S.; Ding, Z.; Jiskoot, W.; Bouwstra, J. A. Co-encapsulation of antigen and Toll-like receptor ligand in cationic liposomes affects the quality of the immune response in mice after intradermal vaccination. Vaccine 2011, 29, 1045-1052

[177] Zhuang, Y.; Ma, Y. F.; Wang, C.; Hai, L.; Yan, C.; Zhang, Y. J.; Liu, F. Z.; Cai, L. T. PEGylated cationic liposomes robustly augment vaccine-induced immune responses: Role of lymphatic trafficking and biodistribution. J. Control. Release 2012, 159, $135-142$.

[178] Kumari, A.; Yadav, S. K.; Yadav, S. C. Biodegradable polymeric nanoparticles based drug delivery systems. Colloids Surf. B Biointerfaces 2010, 75, 1-18.

[179] Makadia, H. K.; Siegel, S. J. Poly lactic-co-glycolic acid (PLGA) as biodegradable controlled drug delivery carrier. Polymers 2011, 3, 1377-1397.

[180] Feczkó, T.; Tóth, J.; Dósa, G.; Gyenis, J. Optimization of protein encapsulation in PLGA nanoparticles. Chem. Eng. Proc. Process Intensificat. 2011, 50, 757-765.

[181] Moon, J. J.; Suh, H.; Polhemus, M. E.; Ockenhouse, C. F.; Yadava, A.; Irvine, D. J. Antigen-displaying lipid-enveloped PLGA nanoparticles as delivery agents for a Plasmodium vivax malaria vaccine. PLoS One 2012, 7, e31472.

[182] Tamada, J. A.; Langer, R. Erosion kinetics of hydrolytically degradable polymers. Proc. Natl. Acad. Sci. USA 1993, 90, 
$552-556$.

[183] Abbasi, E.; Aval, S. F.; Akbarzadeh, A.; Milani, M.; Nasrabadi, H. T.; Joo, S. W.; Hanifehpour, Y.; Nejati-Koshki, K.; Pashaei-Asl, R. Dendrimers: Synthesis, applications, and properties. Nanoscale Res. Lett. 2014, 9, 247.

[184] Kannan, R. M.; Nance, E.; Kannan, S.; Tomalia, D. A. Emerging concepts in dendrimer-based nanomedicine: From design principles to clinical applications. J. Intern. Med. 2014, 276, 579-617.

[185] Braun, C. S.; Vetro, J. A.; Tomalia, D. A.; Koe, G. S.; Koe, J. G.; Middaugh, C. R. Structure/function relationships of polyamidoamine/DNA dendrimers as gene delivery vehicles. $J$. Pharm. Sci. 2005, 94, 423-436.

[186] Daftarian, P.; Kaifer, A. E.; Li, W.; Blomberg, B. B.; Frasca, D.; Roth, F.; Chowdhury, R.; Berg, E. A.; Fishman, J. B.; Al Sayegh, H. A. et al. Peptide-conjugated PAMAM dendrimer as a universal DNA vaccine platform to target antigen-presenting cells. Cancer Res. 2011, 71, 7452-7462.

[187] Ma, C.; Zhu, D. D.; Chen, Y.; Dong, Y. W.; Lin, W. Y.; Li, N.; Zhang, W. J.; Liu, X. X. Amphiphilic peptide dendrimer-based nanovehicles for safe and effective siRNA delivery. Biophys. Rep. 2020, 6, 278-289.

[188] Hong, F.; Zhang, F.; Liu, Y.; Yan, H. DNA origami: Scaffolds for creating higher order structures. Chem. Rev. 2017, 117, 12584-12640.

[189] Eskandari, S.; Guerin, T.; Toth, I.; Stephenson, R. J. Recent advances in self-assembled peptides: Implications for targeted drug delivery and vaccine engineering. Adv. Drug Deliv. Rev. 2017, 110-111,169-187.

[190] López-Sagaseta, J.; Malito, E.; Rappuoli, R.; Bottomley, M. J. Selfassembling protein nanoparticles in the design of vaccines. Comput. Struct. Biotechnol. J. 2016, 14, 58-68.

[191] Kim, I.; Moon, J. S.; Oh, J. W. Recent advances in M13 bacteriophage-based optical sensing applications. Nano Converg. 2016, 3, 27 .

[192] Moon, J. S.; Kim, W. G.; Kim, C.; Park, G. T.; Heo, J.; Yoo, S. Y.; Oh, J. W. M13 bacteriophage-based self-assembly structures and their functional capabilities. Mini. Rev. Org. Chem. 2015, 12, 271-281.

[193] Henry, K. A.; Arbabi-Ghahroudi, M.; Scott, J. K. Beyond phage display: Non-traditional applications of the filamentous bacteriophage as a vaccine carrier, therapeutic biologic, and bioconjugation scaffold. Front. Microbiol. 2015, 6, 755.

[194] Anselmo, A. C.; Mitragotri, S. A review of clinical translation of inorganic nanoparticles. AAPS J. 2015, 17, 1041-1054

[195] He, H.; Pham-Huy, L. A.; Dramou, P.; Xiao, D. L.; Zuo, P. L.; Pham-Huy, C. Carbon nanotubes: Applications in pharmacy and medicine. BioMed Res. Int. 2013, 2013, 578290.

[196] Niikura, K.; Matsunaga, T.; Suzuki, T.; Kobayashi, S.; Yamaguchi, H.; Orba, Y.; Kawaguchi, A.; Hasegawa, H.; Kajino, K.; Ninomiya, $\mathrm{T}$. et al. Gold nanoparticles as a vaccine platform: Influence of size and shape on immunological responses in vitro and in vivo. ACS Nano 2013, 7, 3926-3938.

[197] Steinman, R. M.; Cohn, Z. A. Identification of a novel cell type in peripheral lymphoid organs of mice. I. Morphology, quantitation, tissue distribution. J. Exp. Med. 1973, 137, 1142-1162.

[198] Palucka, K.; Banchereau, J. Dendritic cells: A link between innate and adaptive immunity. J. Clin. Immunol. 1999, 19, 12-25.

[199] Mehta-Damani, A.; Markowicz, S.; Engleman, E. G. Generation of antigen-specific $\mathrm{CD}^{+} \mathrm{T}$ cell lines from naive precursors. Eur. J. Immunol. 1995, 25, 1206-1211.

[200] Mehta-Damani, A.; Markowicz, S.; Engleman, E. G. Generation of antigen-specific $\mathrm{CD}^{+} \mathrm{CTLs}$ from naive precursors. J. Immunol. 1994, 153, 996-1003.

[201] Steinman, R. M.; Nussenzweig, M. C. Avoiding horror autotoxicus: The importance of dendritic cells in peripheral $\mathrm{T}$ cell tolerance. Proc. Natl. Acad. Sci. USA 2002, 99, 351-358.

[202] Bonifaz, L.; Bonnyay, D.; Mahnke, K.; Rivera, M.; Nussenzweig, M. C.; Steinman, R. M. Efficient targeting of protein antigen to the dendritic cell receptor DEC-205 in the steady state leads to antigen presentation on major histocompatibility complex class I products and peripheral $\mathrm{CD}^{+} \mathrm{T}$ cell tolerance. J. Exp. Med. 2002, 196,
$1627-1638$.

[203] Hawiger, D.; Inaba, K.; Dorsett, Y.; Guo, M.; Mahnke, K.; Rivera, M.; Ravetch, J. V.; Steinman, R. M.; Nussenzweig, M. C. Dendritic cells induce peripheral $\mathrm{T}$ cell unresponsiveness under steady state conditions in vivo. J. Exp. Med. 2001, 194, 769-779.

[204] Soares, H.; Waechter, H.; Glaichenhaus, N.; Mougneau, E.; Yagita, H.; Mizenina, O.; Dudziak, D.; Nussenzweig, M. C.; Steinman, R. M. A subset of dendritic cells induces $\mathrm{CD}^{+} \mathrm{T}$ cells to produce IFN$\gamma$ by an IL-12-independent but CD70-dependent mechanism in vivo. J. Exp. Med. 2007, 204, 1095-1106.

[205] Albert, M. L.; Pearce, S. F. A.; Francisco, L. M.; Sauter, B.; Roy, P.; Silverstein, R. L.; Bhardwaj, N. Immature dendritic cells phagocytose apoptotic cells via $\alpha_{\mathrm{v}} \beta_{5}$ and CD36, and cross-present antigens to cytotoxic T lymphocytes. J. Exp. Med. 1998, 188, 1359-1368.

[206] de Baey, A.; Lanzavecchia, A. The role of aquaporins in dendritic cell macropinocytosis. J. Exp. Med. 2000, 191, 743-748.

[207] Geijtenbeek, T. B. H.; Gringhuis, S. I. Signalling through C-type lectin receptors: Shaping immune responses. Nat. Rev. Immunol. 2009, 9, 465-479.

[208] Kawasaki, T.; Kawai, T. Toll-like receptor signaling pathways. Front. Immunol. 2014, 5, 461 .

[209] Trombetta, E. S.; Mellman, I. Cell biology of antigen processing in vitro and in vivo. Annu. Rev. Immunol. 2005, 23, 975-1028.

[210] Fujimoto, Y.; Tu, L. L.; Miller, A. S.; Bock, C.; Fujimoto, M.; Doyle, C.; Steeber, D. A.; Tedder, T. F. CD83 expression influences $\mathrm{CD}^{+} \mathrm{T}$ cell development in the thymus. Cell 2002, 108, $755-767$.

[211] Kurd, N.; Robey, E. A. T-cell selection in the thymus: A spatial and temporal perspective. Immunol. Rev. 2016, 271, 114-126.

[212] Vacchio, M. S.; Bosselut, R. What happens in the thymus does not stay in the thymus: How $\mathrm{T}$ cells recycle the $\mathrm{CD} 4^{+}-\mathrm{CD} 8^{+}$lineage commitment transcriptional circuitry to control their function. $J$. Immunol. 2016, 196, 4848-4856.

[213] Pennock, N. D.; White, J. T.; Cross, E. W.; Cheney, E. E.; Tamburini, B. A.; Kedl, R. M. T cell responses: Naive to memory and everything in between. Adv. Physiol. Educ. 2013, 37, 273-283.

[214] Nurieva, R. I.; Chung, Y. Understanding the development and function of $\mathrm{T}$ follicular helper cells. Cell. Mol. Immunol. 2010, 7 , 190-197.

[215] Dalod, M.; Chelbi, R.; Malissen, B.; Lawrence, T. Dendritic cell maturation: Functional specialization through signaling specificity and transcriptional programming. EMBO J. 2014, 33, 1104-1116.

[216] Blum, J. S.; Wearsch, P. A.; Cresswell, P. Pathways of antigen processing. Annu. Rev. Immunol. 2013, 31, 443-473.

[217] Embgenbroich, M.; Burgdorf, S. Current concepts of antigen crosspresentation. Front. Immunol. 2018, 9, 1643.

[218] Lanzavecchia, A. Mechanisms of antigen uptake for presentation. Curr. Opin. Immunol. 1996, 8, 348-354.

[219] Reddy, S. T.; Rehor, A.; Schmoekel, H. G.; Hubbell, J. A.; Swartz, M. A. In vivo targeting of dendritic cells in lymph nodes with poly(propylene sulfide) nanoparticles. J. Control. Release 2006, 112, 26-34.

[220] Cho, K.; Wang, X.; Nie, S. M.; Chen, Z.; Shin, D. M. Therapeutic nanoparticles for drug delivery in cancer. Clin. Cancer Res. 2008, 14, 1310-1316.

[221] Moghimi, S. M.; Hunter, A. C.; Murray, J. C. Long-circulating and target-specific nanoparticles: Theory to practice. Pharmacol. Rev. 2001, 53, 283-318.

[222] Wei, Y. C.; Quan, L.; Zhou, C.; Zhan, Q. Q. Factors relating to the biodistribution \& clearance of nanoparticles \& their effects on in vivo application. Nanomedicine 2018, 13, 1495-1512.

[223] Narasimhan, B.; Goodman, J. T.; Vela Ramirez, J. E. Rational design of targeted next-generation carriers for drug and vaccine delivery. Annu. Rev. Biomed. Eng. 2016, 18, 25-49.

[224] Peek, L. J.; Middaugh, C. R.; Berkland, C. Nanotechnology in vaccine delivery. Adv. Drug Deliv. Rev. 2008, 60, 915-928.

[225] Ura, T.; Okuda, K.; Shimada, M. Developments in viral vectorbased vaccines. Vaccines 2014, 2, 624-641.

[226] Biswas, S. K.; Boutz, P. L.; Nayak, D. P. Influenza virus nucleoprotein interacts with influenza virus polymerase proteins. $J$. 
Virol. 1998, 72, 5493-5501.

[227] Portela, A.; Digard, P. The influenza virus nucleoprotein: A multifunctional RNA-binding protein pivotal to virus replication. $J$. Gen. Virol. 2002, 83, 723-734.

[228] Keech, C.; Albert, G.; Cho, I.; Robertson, A.; Reed, P.; Neal, S.; Plested, J. S.; Zhu, M. Z.; Cloney-Clark, S.; Zhou, H. X. et al. Phase 1-2 trial of a SARS-CoV-2 recombinant spike protein nanoparticle vaccine. N. Engl. J. Med. 2020, 383, 2320-2332.

[229] Blanco, E.; Shen, H. F.; Ferrari, M. Principles of nanoparticle design for overcoming biological barriers to drug delivery. Nat. Biotechnol. 2015, 33, 941-951.

[230] Monopoli, M. P.; Åberg, C.; Salvati, A.; Dawson, K. A. Biomolecular coronas provide the biological identity of nanosized materials. Nat. Nanotechnol. 2012, 7, 779-786.

[231] Ritz, S.; Schöttler, S.; Kotman, N.; Baier, G.; Musyanovych, A.; Kuharev, J.; Landfester, K.; Schild, H.; Jahn, O.; Tenzer, S. et al. Protein corona of nanoparticles: Distinct proteins regulate the cellular uptake. Biomacromolecules 2015, 16, 1311-1321.

[232] Billeskov, R.; Beikzadeh, B.; Berzofsky, J. A. The effect of antigen dose on $\mathrm{T}$ cell-targeting vaccine outcome. Hum. Vaccin. Immunother. 2019, 15, 407-411.

[233] Arvin, A. M.; Fink, K.; Schmid, M. A.; Cathcart, A.; Spreafico, R.; Havenar-Daughton, C.; Lanzavecchia, A.; Corti, D.; Virgin, H. W. A perspective on potential antibody-dependent enhancement of SARS-CoV-2. Nature 2020, 584, 353-363.

[234] Vert, M.; Doi, Y.; Hellwich, K. H.; Hess, M.; Hodge, P.; Kubisa, P.; Rinaudo, M.; Schué, F. Terminology for biorelated polymers and applications (IUPAC Recommendations 2012). Pure Appl. Chem. 2012, 84, 377-410.

[235] Zhao, J. C.; Stenzel, M. H. Entry of nanoparticles into cells: The importance of nanoparticle properties. Polym. Chem. 2018, 9, 259-272.

[236] Behzadi, S.; Serpooshan, V.; Tao, W.; Hamaly, M. A.; Alkawareek, M. Y.; Dreaden, E. C.; Brown, D.; Alkilany, A. M.; Farokhzad, O. C.; Mahmoudi, M. Cellular uptake of nanoparticles: Journey inside the cell. Chem. Soc. Rev. 2017, 46, 4218-4244.

[237] Foroozandeh, P.; Aziz, A. A. Insight into cellular uptake and intracellular trafficking of nanoparticles. Nanoscale Res. Lett. 2018, $13,339$.

[238] Bachmann, M. F.; Jennings, G. T. Vaccine delivery: A matter of size, geometry, kinetics and molecular patterns. Nat. Rev. Immunol. 2010, 10, 787-796.

[239] Moghimi, S. M.; Patel, H. M. Serum-mediated recognition of liposomes by phagocytic cells of the reticuloendothelial system-the concept of tissue specificity. Adva. Drug Deliv. Rev. 1998, 32, 45-60.

[240] Storm, G.; Belliot, S. O.; Daemen, T.; Lasic, D. D. Surface modification of nanoparticles to oppose uptake by the mononuclear phagocyte system. Adv. Drug Deliv. Rev. 1995, 17, 31-48.

[241] Anselmo, A. C.; Mitragotri, S. Nanoparticles in the clinic: An update. Bioeng. Transl. Med. 2019, 4, e10143.

[242] Bulbake, U.; Doppalapudi, S.; Kommineni, N.; Khan, W. Liposomal formulations in clinical use: An updated review. Pharmaceutics 2017, 9, 12.

[243] Ventola, C. L. Progress in nanomedicine: Approved and investigational nanodrugs. P T 2017, 42, 742-755.

[244] Talmage, D. W. The acceptance and rejection of immunological concepts. Annu. Rev. Immunol. 1986, 4, 1-12.

[245] Strugnell, R.; Zepp, F.; Cunningham, A.; Tantawichien, T. Vaccine antigens. Perspect. Vaccinol. 2011, 1, 61-88.

[246] Hamborg, M.; Jorgensen, L.; Bojsen, A. R.; Christensen, D.; Foged, C. Protein antigen adsorption to the DDA/TDB liposomal adjuvant: Effect on protein structure, stability, and liposome physicochemical characteristics. Pharm. Res. 2013, 30, 140-155.

[247] Hansen, B.; Sokolovska, A.; HogenEsch, H.; Hem, S. L. Relationship between the strength of antigen adsorption to an aluminum-containing adjuvant and the immune response. Vaccine 2007, 25, 6618-6624.

[248] Blakney, A. K.; McKay, P. F.; Yus, B. I.; Aldon, Y.; Shattock, R. J. Inside out: Optimization of lipid nanoparticle formulations for exterior complexation and in vivo delivery of saRNA. Gene Ther 2019, 26, 363-372.

[249] Takamura, S.; Niikura, M.; Li, T. C.; Takeda, N.; Kusagawa, S. Takebe, Y.; Miyamura, T.; Yasutomi, Y. DNA vaccineencapsulated virus-like particles derived from an orally transmissible virus stimulate mucosal and systemic immune responses by oral administration. Gene Ther. 2004, 11, 628-635.

[250] Cao, P.; Han, F. Y.; Grøndahl, L.; Xu, Z. P.; Li, L. Enhanced oral vaccine efficacy of polysaccharide-coated calcium phosphate nanoparticles. ACS Omega 2020, 5, 18185-18197.

[251] Pawar, D.; Mangal, S.; Goswami, R.; Jaganathan, K. S. Development and characterization of surface modified PLGA nanoparticles for nasal vaccine delivery: Effect of mucoadhesive coating on antigen uptake and immune adjuvant activity. Eur. $J$ Pharm. Biopharm. 2013, 85, 550-559.

[252] van Broekhoven, C. L.; Parish, C. R.; Demangel, C.; Britton, W. J.; Altin, J. G. Targeting dendritic cells with antigen-containing liposomes. Cancer Res. 2004, 64, 4357-4365.

[253] Zeng, B. J.; Middelberg, A. P. J.; Gemiarto, A.; MacDonald, K.; Baxter, A. G.; Talekar, M.; Moi, D.; Tullett, K. M.; Caminschi, I.; Lahoud, M. H. et al. Self-adjuvanting nanoemulsion targeting dendritic cell receptor Clec9A enables antigen-specific immunotherapy. J. Clin. Invest. 2018, 128, 1971-1984.

[254] de Titta, A.; Ballester, M.; Julier, Z.; Nembrini, C.; Jeanbart, L.; van der Vlies, A. J.; Swartz, M. A.; Hubbell, J. A. Nanoparticle conjugation of $\mathrm{CpG}$ enhances adjuvancy for cellular immunity and memory recall at low dose. Proc. Natl. Acad. Sci. USA 2013, 110, 19902-19907.

[255] Scaria, P. V.; Chen, B.; Rowe, C. G.; Jones, D. S.; Barnafo, E.; Fischer, E. R.; Anderson, C.; MacDonald, N. J.; Lambert, L.; Rausch, K. M. et al. Protein-protein conjugate nanoparticles for malaria antigen delivery and enhanced immunogenicity. PLoS One 2017, 12, e0190312.

[256] Friedman, A. D.; Claypool, S. E.; Liu, R. H. The smart targeting of nanoparticles. Curr. Pharm. Des. 2013, 19, 6315-6329.

[257] Jeanbart, L.; Ballester, M.; de Titta, A.; Corthésy, P.; Romero, P.; Hubbell, J. A.; Swartz, M. A. Enhancing efficacy of anticancer vaccines by targeted delivery to tumor-draining lymph nodes. Cancer Immunol. Res. 2014, 2, 436-447.

[258] Harding, C. V.; Collins, D. S.; Slot, J. W.; Geuze, H. J.; Unanue, E. R. Liposome-encapsulated antigens are processed in lysosomes, recycled, and presented to T cells. Cell 1991, 64, 393-401.

[259] Sancho, D.; Reis e Sousa, C. Signaling by myeloid C-type lectin receptors in immunity and homeostasis. Annu. Rev. Immunol. 2012, 30, 491-529.

[260] Azad, A. K.; Rajaram, M. V. S.; Schlesinger, L. S. Exploitation of the macrophage mannose receptor (CD206) in infectious disease diagnostics and therapeutics. J. Cytol. Mol. Biol. 2014, 1, 1000003.

[261] Ponka, P.; Lok, C. N. The transferrin receptor: Role in health and disease. Int. J. Biochem. Cell Biol. 1999, 31, 1111-1137.

[262] Nimmerjahn, F.; Ravetch, J. V. Fcy receptors as regulators of immune responses. Nat. Rev. Immunol. 2008, 8, 34-47.

[263] Treanor, B. B-cell receptor: From resting state to activate. Immunology 2012, 136, 21-27.

[264] Al-Barwani, F.; Young, S. L.; Baird, M. A.; Larsen, D. S.; Ward, V. K. Mannosylation of virus-like particles enhances internalization by antigen presenting cells. PLoS One 2014, 9, e104523.

[265] Hong, S.; Zhang, Z. M.; Liu, H. T.; Tian, M. J.; Zhu, X. P.; Zhang, Z. Q.; Wang, W. H.; Zhou, X. Y.; Zhang, F. P.; Ge, Q. et al. B Cells are the dominant antigen-presenting cells that activate naive $\mathrm{CD}^{+} \mathrm{T}$ cells upon immunization with a virus-derived nanoparticle antigen. Immunity 2018, 49, 695-708.e4.

[266] Storni, T.; Lechner, F.; Erdmann, I.; Bächi, T.; Jegerlehner, A.; Dumrese, T.; Kündig, T. M.; Ruedl, C.; Bachmann, M. F. Critical role for activation of antigen-presenting cells in priming of cytotoxic $\mathrm{T}$ cell responses after vaccination with virus-like particles. J. Immunol. 2002, 168, 2880-2886.

[267] Tanaka, Y.; Taneichi, M.; Kasai, M.; Kakiuchi, T.; Uchida, T. Liposome-coupled antigens are internalized by antigen-presenting cells via pinocytosis and cross-presented to $\mathrm{CD} 8^{+} \mathrm{T}$ cells. PLoS One 
2010, $5, \mathrm{e} 15225$.

[268] Taneichi, M.; Ishida, H.; Kajino, K.; Ogasawara, K.; Tanaka, Y.; Kasai, M.; Mori, M.; Nishida, M.; Yamamura, H.; Mizuguchi, J. et al. Antigen Chemically coupled to the surface of liposomes are cross-presented to $\mathrm{CD}^{+} \mathrm{T}$ cells and induce potent antitumor immunity. J. Immunol. 2006, 177, 2324-2330.

[269] Dykman, L. A. Gold nanoparticles for preparation of antibodies and vaccines against infectious diseases. Expert Rev. Vaccines 2020, 19, 465-477.

[270] Wang, C.; Zhu, W. D.; Luo, Y.; Wang, B. Z. Gold nanoparticles conjugating recombinant influenza hemagglutinin trimers and flagellin enhanced mucosal cellular immunity. Nanomedicine:Nanotechnol. Biol. Med. 2018, 14, 1349-1360.

[271] Zhou, Q. Q.; Zhang, Y. L.; Du, J.; Li, Y.; Zhou, Y.; Fu, Q. X.; Zhang, J. G.; Wang, X. H.; Zhan, L. S. Different-sized gold nanoparticle activator/antigen increases dendritic cells accumulation in liver-draining lymph nodes and $\mathrm{CD}^{+} \mathrm{T}$ cell responses. ACS Nano 2016, 10, 2678-2692.

[272] Raghuwanshi, D.; Mishra, V.; Das, D.; Kaur, K.; Suresh, M. R. Dendritic cell targeted chitosan nanoparticles for nasal DNA immunization against SARS CoV nucleocapsid protein. Mol. Pharm. 2012, 9, 946-956.

[273] Brenner, S.; Jacob, F.; Meselson, M. An unstable intermediate carrying information from genes to ribosomes for protein synthesis. Nature 1961, 190, 576-581.

[274] Wolff, J. A.; Malone, R. W.; Williams, P.; Chong, W.; Acsadi, G.; Jani, A.; Felgner, P. L. Direct gene transfer into mouse muscle in vivo. Science 1990, 247, 1465-1468.

[275] Garneau, N. L.; Wilusz, J.; Wilusz, C. J. The highways and byways of mRNA decay. Nat. Rev. Mol. Cell Biol. 2007, 8, 113-126.

[276] Ross, J. mRNA stability in mammalian cells. Microbiol. Rev. 1995, $59,423-450$.

[277] Holtkamp, S.; Kreiter, S.; Selmi, A.; Simon, P.; Koslowski, M.; Huber, C.; Türeci, O.; Sahin, U. Modification of antigen-encoding RNA increases stability, translational efficacy, and T-cell stimulatory capacity of dendritic cells. Blood 2006, 108, 4009-4017.

[278] Pascolo, S. Vaccination with messenger RNA (mRNA). In TollLike Receptors (TLRs) and Innate Immunity. Bauer, S.; Hartmann, G., Eds.; Springer: Berlin, Heidelberg, 2008; pp 221-235.

[279] Pardi, N.; Hogan, M. J.; Porter, F. W.; Weissman, D. mRNA vaccines-a new era in vaccinology. Nat. Rev. Drug Dis. 2018, 17, 261-279.

[280] Brito, L. A.; Kommareddy, S.; Maione, D.; Uematsu, Y.; Giovani, C.; Berlanda Scorza, F.; Otten, G. R.; Yu, D.; Mandl, C. W.; Mason, P. W. et al. Self-amplifying mRNA vaccines. Adv. Genet. 2015, 89, 179-233.

[281] Schlake, T.; Thess, A.; Fotin-Mleczek, M.; Kallen, K. J. Developing mRNA-vaccine technologies. RNA Biol. 2012, 9, 1319-1330.

[282] Sato, K.; Akiyama, M.; Sakakibara, Y. RNA secondary structure prediction using deep learning with thermodynamic integration. Nat. Commun. 2021, 12, 941.

[283] Mao, K. K.; Wang, J.; Xiao, Y. Prediction of RNA secondary structure with pseudoknots using coupled deep neural networks. Biophys. Rep. 2020, 6, 146-154.

[284] Bellaousov, S.; Reuter, J. S.; Seetin, M. G.; Mathews, D. H. RNAstructure: Web servers for RNA secondary structure prediction and analysis. Nucleic Acids Res. 2013, 41, W471-W474.

[285] Janssen, S.; Giegerich, R. The RNA shapes studio. Bioinformatics 2015, 31, 423-425

[286] Zeng, C. X.; Hou, X. C.; Yan, J. Y.; Zhang, C. X.; Li, W. Q.; Zhao, W. Y.; Du, S.; Dong, Y. Z. Leveraging mRNA sequences and nanoparticles to deliver SARS-CoV-2 antigens in vivo. Adv. Mater. 2020, 32, 2004452.

[287] Wrapp, D.; Wang, N.; Corbett, K. S.; Goldsmith, J. A.; Hsieh, C. L.; Abiona, O.; Graham, B. S.; McLellan, J. S. Cryo-EM structure of the 2019-nCoV spike in the prefusion conformation. Science 2020, 367, 1260-1263.

[288] Hassett, K. J.; Benenato, K. E.; Jacquinet, E.; Lee, A.; Woods, A.; Yuzhakov, O.; Himansu, S.; Deterling, J.; Geilich, B. M.; Ketova,
T. et al. Optimization of lipid nanoparticles for intramuscular administration of mRNA vaccines. Mol. Ther. Nucleic Acids 2019, $15,1-11$.

[289] Graham, B. S.; Gilman, M. S. A.; McLellan, J. S. Structure-based vaccine antigen design. Annu. Rev. Med. 2019, 70, 91-104.

[290] Jackson, L. A.; Anderson, E. J.; Rouphael, N. G.; Roberts, P. C.; Makhene, M.; Coler, R. N.; McCullough, M. P.; Chappell, J. D.; Denison, M. R.; Stevens, L. J. et al. An mRNA vaccine against SARS-CoV-2-preliminary report. N. Engl. J. Med. 2020, 383, 1920-1931.

[291] Baden, L. R.; El Sahly, H. M.; Essink, B.; Kotloff, K.; Frey, S.; Novak, R.; Diemert, D.; Spector, S. A.; Rouphael, N.; Creech, C. B. et al. Efficacy and Safety of the mRNA-1273 SARS-CoV-2 Vaccine. N. Engl. J. Med. 2021, 384, 403-416.

[292] Wang, P. F.; Nair, M. S.; Liu, L. H.; Iketani, S.; Luo, Y.; Guo, Y. C.; Wang, M.; Yu, J.; Zhang, B. S.; Kwong, P. D. et al. Antibody resistance of SARS-CoV-2 variants B. 1.351 and B. 1.1. 7. Nature 2021, 593, 130-135.

[293] Wu, K.; Werner, A. P.; Koch, M.; Choi, A.; Narayanan, E.; StewartJones, G. B. E.; Colpitts, T.; Bennett, H.; Boyoglu-Barnum, S.; Shi, W. et al. Serum neutralizing activity elicited by mRNA-1273 vaccine. N. Engl. J. Med. 2021, 384, 1468-1470.

[294] Karikó, K.; Muramatsu, H.; Welsh, F. A.; Ludwig, J.; Kato, H.; Akira, S.; Weissman, D. Incorporation of pseudouridine into mRNA yields superior nonimmunogenic vector with increased translational capacity and biological stability. Mol. Ther. 2008, 16, 1833-1840.

[295] Tai, W. B.; Zhao, G. Y.; Sun, S. H.; Guo, Y.; Wang, Y. F.; Tao, X. R.; Tseng, C. T. K.; Li, F.; Jiang, S. B.; Du, L. Y. et al. A recombinant receptor-binding domain of MERS-CoV in trimeric form protects human dipeptidyl peptidase 4 (hDPP4) transgenic mice from MERS-CoV infection. Virology 2016, 499, 375-382.

[296] Kranz, L. M.; Diken, M.; Haas, H.; Kreiter, S.; Loquai, C.; Reuter, K. C.; Meng, M.; Fritz, D.; Vascotto, F.; Hefesha, H. et al. Systemic RNA delivery to dendritic cells exploits antiviral defence for cancer immunotherapy. Nature 2016, 534, 396-401.

[297] Mulligan, M. J.; Lyke, K. E.; Kitchin, N.; Absalon, J.; Gurtman, A.; Lockhart, S.; Neuzil, K.; Raabe, V.; Bailey, R.; Swanson, K. A. et al. Phase I/II study of COVID-19 RNA vaccine BNT162b1 in adults. Nature 2020, 586, 589-593.

[298] Walsh, E. E.; Frenck, R. W. Jr.; Falsey, A. R.; Kitchin, N.; Absalon, J.; Gurtman, A.; Lockhart, S.; Neuzil, K.; Mulligan, M. J.; Bailey, R. et al. Safety and immunogenicity of two RNA-based Covid-19 vaccine candidates. N. Engl. J. Med. 2020, 383, 2439-2450.

[299] Polack, F. P.; Thomas, S. J.; Kitchin, N.; Absalon, J.; Gurtman, A.; Lockhart, S.; Perez, J. L.; Pérez Marc, G.; Moreira, E. D.; Zerbini, C. et al. Safety and efficacy of the BNT162b2 mRNA Covid-19 vaccine. N. Engl. J. Med. 2020, 383, 2603-2615.

[300] Planas, D.; Bruel, T.; Grzelak, L.; Guivel-Benhassine, F.; Staropoli, I.; Porrot, F.; Planchais, C.; Buchrieser, J.; Rajah, M. M.; Bishop, E. et al. Sensitivity of infectious SARS-CoV-2 B. 1.1. 7 and B. 1.351 variants to neutralizing antibodies. Nat. Med. 2021, 27, 917-924.

[301] Jose, J.; Snyder, J. E.; Kuhn, R. J. A structural and functional perspective of alphavirus replication and assembly. Future Microbiol. 2009, 4, 837-856.

[302] Atkins, G. J.; Fleeton, M. N.; Sheahan, B. J. Therapeutic and prophylactic applications of alphavirus vectors. Expert Rev. Mol. Med. 2008, 10, e33.

[303] Lundstrom, K. Alphaviruses in gene therapy. Viruses 2015, 7, 2321-2333.

[304] Tubulekas, I.; Berglund, P.; Fleeton, M.; Liljeström, P. Alphavirus expression vectors and their use as recombinant vaccines: A minireview. Gene 1997, 190, 191-195.

[305] Zhou, X.; Berglund, P.; Rhodes, G.; Parker, S. E.; Jondal, M.; Liljeström, P. Self-replicating Semliki Forest virus RNA as recombinant vaccine. Vaccine 1994, 12, 1510-1514.

[306] Vogel, A. B.; Lambert, L.; Kinnear, E.; Busse, D.; Erbar, S.; Reuter, K. C.; Wicke, L.; Perkovic, M.; Beissert, T.; Haas, H. et al. Self-amplifying RNA vaccines give equivalent protection against 
influenza to mRNA vaccines but at much lower doses. Mol. Ther. 2018, 26, 446-455.

[307] Geall, A. J.; Verma, A.; Otten, G. R.; Shaw, C. A.; Hekele, A.; Banerjee, K.; Cu, Y.; Beard, C. W.; Brito, L. A.; Krucker, T. et al. Nonviral delivery of self-amplifying RNA vaccines. Proc. Natl. Acad. Sci. USA 2012, 109, 14604-14609.

[308] Goswami, R.; Chatzikleanthous, D.; Lou, G.; Giusti, F.; Bonci, A.; Taccone, M.; Brazzoli, M.; Gallorini, S.; Ferlenghi, I.; Berti, F. et al. Mannosylation of LNP results in improved potency for selfamplifying RNA (SAM) vaccines. ACS Infect. Dis. 2019, 5, 1546-1558.

[309] Kirchdoerfer, R. N.; Wang, N. S.; Pallesen, J.; Wrapp, D.; Turner, H. L.; Cottrell, C. A.; Corbett, K. S.; Graham, B. S.; McLellan, J. S.; Ward, A. B. Stabilized coronavirus spikes are resistant to conformational changes induced by receptor recognition or proteolysis. Sci. Rep. 2018, 8, 15701 .

[310] Blakney, A. K.; McKay, P. F.; Shattock, R. J. Structural Components for amplification of positive and negative strand VEEV splitzicons. Front. Mol. Biosci. 2018, 5, 71.

[311] Pardi, N.; Tuyishime, S.; Muramatsu, H.; Kariko, K.; Mui, B. L.; Tam, Y. K.; Madden, T. D.; Hope, M. J.; Weissman, D. Expression kinetics of nucleoside-modified mRNA delivered in lipid nanoparticles to mice by various routes. J Control. Release 2015, 217, 345-351.

[312] McKay, P. F.; Hu, K.; Blakney, A. K.; Samnuan, K.; Brown, J. C.; Penn, R.; Zhou, J.; Bouton, C. R.; Rogers, P.; Polra, K. et al. Selfamplifying RNA SARS-CoV-2 lipid nanoparticle vaccine candidate induces high neutralizing antibody titers in mice. Nat. Commun. 2020, 11, 3523.

[313] Kinney, R. M.; Chang, G. J.; Tsuchiya, K. R.; Sneider, J. M.; Roehrig, J. T.; Woodward, T. M.; Trent, D. W. Attenuation of Venezuelan equine encephalitis virus strain TC- 83 is encoded by the 5'-noncoding region and the E2 envelope glycoprotein. J. Virol. 1993, 67, 1269-1277.

[314] Desbien, A. L.; Reed, S. J.; Bailor, H. R.; Cauwelaert, N. D.; Laurance, J. D.; Orr, M. T.; Fox, C. B.; Carter, D.; Reed, S. G.; Duthie, M. S. Squalene emulsion potentiates the adjuvant activity of the TLR4 agonist, GLA, via inflammatory caspases, IL-18, and IFN- $\gamma$. Eur. J. Immunol. 2015, 45, 407-417.

[315] Yu, E. Y.; Chandrasekharan, P.; Berzon, R.; Tay, Z. W.; Zhou, X. Y.; Khandhar, A. P.; Ferguson, R. M.; Kemp, S. J.; Zheng, B.; Goodwill, P. W. et al. Magnetic particle imaging for highly sensitive, quantitative, and safe in vivo gut bleed detection in a Murine model. ACS Nano 2017, 11, 12067-12076.

[316] Erasmus, J. H.; Khandhar, A. P.; O'Connor, M. A.; Walls, A. C.; Hemann, E. A.; Murapa, P.; Archer, J.; Leventhal, S.; Fuller, J. T.; Lewis, T. B. et al. An Alphavirus-derived replicon RNA vaccine induces SARS-CoV-2 neutralizing antibody and T cell responses in mice and nonhuman primates. Sci. Transl. Med. 2020, 12, eabc9396.

[317] Kay, M. A.; He, C. Y.; Chen, Z. Y. A robust system for production of minicircle DNA vectors. Nat. Biotechnol. 2010, 28, 1287-1289.

[318] Schleef, M.; Schirmbeck, R.; Reiser, M.; Michel, M. L.; Schmeer, M. Minicircle: Next generation DNA vectors for vaccination. Methods Mol. Biol. 2015, 1317, 327-339.

[319] Farris, E.; Brown, D. M.; Ramer-Tait, A. E.; Pannier, A. K. Microand nanoparticulates for DNA vaccine delivery. Exp. Biol. Med. 2016, 241, 919-929.

[320] McCluskie, M. J.; Brazolot Millan, C. L.; Gramzinski, R. A.; Robinson, H. L.; Santoro, J. C.; Fuller, J. T.; Widera, G.; Haynes, J. R.; Purcell, R. H.; Davis, H. L. Route and method of delivery of DNA vaccine influence immune responses in mice and non-human primates. Mol. Med. 1999, 5, 287-300.

[321] Xu, Y. Y.; Yuen, P. W.; Lam, J. K. W. Intranasal DNA vaccine for protection against respiratory infectious diseases: The delivery perspectives. Pharmaceutics 2014, 6, 378-415.

[322] Cui, Z. R. DNA vaccine. Adv. Genet. 2005, 54, 257-289.

[323] Ulmer, J. B.; Donnelly, J. J.; Parker, S. E.; Rhodes, G. H.; Felgner, P. L.; Dwarki, V. J.; Gromkowski, S. H.; Deck, R. R.; DeWitt, C. M.; Friedman, A. et al. Heterologous protection against influenza by injection of DNA encoding a viral protein. Science 1993, 259, 1745-1749.

[324] Quaak, S. G. L.; Haanen, J. B. A. G.; Beijnen, J. H.; Nuijen, B. Naked plasmid DNA formulation: Effect of different disaccharides on stability after lyophilisation. AAPS PharmSciTech 2010, 11, 344-350.

[325] Carabineiro, S. A. C. Applications of gold nanoparticles in nanomedicine: Recent advances in vaccines. Molecules 2017, 22, 857.

[326] Dean, H. J.; Fuller, D.; Osorio, J. E. Powder and particle-mediated approaches for delivery of DNA and protein vaccines into the epidermis. Comp. Immunol., Microbiology and Infectious Diseases 2003, 26, 373-388.

[327] Perrie, Y.; Frederik, P. M.; Gregoriadis, G. Liposome-mediated DNA vaccination: The effect of vesicle composition. Vaccine 2001, 19, 3301-3310

[328] Wang, Z.; Troilo, P. J.; Wang, X.; Griffiths II, T. G.; Pacchione, S. J.; Barnum, A. B.; Harper, L. B.; Pauley, C. J.; Niu, Z.; Denisova, L. et al. Detection of integration of plasmid DNA into host genomic DNA following intramuscular injection and electroporation. Gene Ther. 2004, 11, 711-721.

[329] Diehl, M. C.; Lee, J. C.; Daniels, S. E.; Tebas, P.; Khan, A. S.; Giffear, M.; Sardesai, N. Y.; Bagarazzi, M. L. Tolerability of intramuscular and intradermal delivery by CELLECTRA ${ }^{\circledast}$ adaptive constant current electroporation device in healthy volunteers. Hum. Vaccin. Immunother. 2013, 9, 2246-2252.

[330] Sardesai, N. Y.; Weiner, D. B. Electroporation delivery of DNA vaccines: Prospects for success. Curr. Opin. Immunol. 2011, 23, 421-429.

[331] Xu, Z. Y.; Wise, M. C.; Choi, H.; Perales-Puchalt, A.; Patel, A.; Tello-Ruiz, E.; Chu, J. D.; Muthumani, K.; Weiner, D. B. Synthetic DNA delivery by electroporation promotes robust in vivo sulfation of broadly neutralizing anti-HIV immunoadhesin eCD4-Ig. EBioMedicine 2018, 35, 97-105.

[332] Smith, T. R. F.; Patel, A.; Ramos, S.; Elwood, D.; Zhu, X. Z.; Yan, J.; Gary, E. N.; Walker, S. N.; Schultheis, K.; Purwar, M. et al. Immunogenicity of a DNA vaccine candidate for COVID-19. Nat. Commun. 2020, 11, 2601.

[333] Noad, R.; Roy, P. Virus-like particles as immunogens. Trends Microbiol. 2003, 11, 438-444.

[334] Fersht, A.; Winter, G. Protein engineering. Trends Biochem. Sci. 1992, 17, 292-294.

[335] Da Silva, D. M.; Velders, M. P.; Nieland, J. D.; Schiller, J. T.; Nickoloff, B. J.; Kast, W. M. Physical interaction of human papillomavirus virus-like particles with immune cells. Int. Immunol. 2001, 13, 633-641.

[336] Nasir, W.; Bally, M.; Zhdanov, V. P.; Larson, G.; Höök, F. Interaction of virus-like particles with vesicles containing glycolipids: Kinetics of detachment. J. Phys. Chem. B 2015, 119, 11466-11472.

[337] Zdanowicz, M.; Chroboczek, J. Virus-like particles as drug delivery vectors. Acta Biochim. Pol. 2016, 63, 469-473.

[338] Schwarz, B.; Uchida, M.; Douglas, T. Chapter one-biomedical and catalytic opportunities of virus-like particles in nanotechnology. Adv. Virus Res. 2017, 97, 1-60.

[339] McAleer, W. J.; Buynak, E. B.; Maigetter, R. Z.; Wampler, D. E.; Miller, W. J.; Hilleman, M. R. Human hepatitis B vaccine from recombinant yeast. Nature 1984, 307, 178-180.

[340] Grgacic, E. V. L.; Anderson, D. A. Virus-like particles: Passport to immune recognition. Methods 2006, 40, 60-65.

[341] Vicente, T.; Roldão, A.; Peixoto, C.; Carrondo, M. J.; Alves, P. M. Large-scale production and purification of VLP-based vaccines. $J$. Invertebr. Pathol. 2011, 107 Suppl, S42-S48.

[342] Zhu, N.; Zhang, D. Y.; Wang, W. L.; Li, X. W.; Yang, B.; Song, J. D.; Zhao, X.; Huang, B. Y.; Shi, W. F.; Lu, R. J. et al. A novel coronavirus from patients with pneumonia in China, 2019. N. Engl. J. Med. 2020, 382, 727-733.

[343] Mortola, E.; Roy, P. Efficient assembly and release of SARS coronavirus-like particles by a heterologous expression system. FEBS Lett. 2004, 576, 174-178. 
[344] Xu, R. D.; Shi, M. F.; Li, J.; Song, P.; Li, N. Construction of SARSCoV-2 virus-like particles by mammalian expression system. Front. Bioeng. Biotechnol. 2020, 8,862 .

[345] Fernandes, F.; Teixeira, A. P.; Carinhas, N.; Carrondo, M. J. T.; Alves, P. M. Insect cells as a production platform of complex viruslike particles. Expert Rev. Vaccines 2013, 12, 225-236.

[346] Liu, F. X.; Wu, X. D.; Li, L.; Liu, Z. S.; Wang, Z. L. Use of baculovirus expression system for generation of virus-like particles: Successes and challenges. Protein Expr. Purif. 2013, 90, 104-116.

[347] Shen, S.; Lin, P. S.; Chao, Y. C.; Zhang, A. H.; Yang, X. M.; Lim, S. G.; Hong, W. J.; Tan, Y. J. The severe acute respiratory syndrome coronavirus $3 \mathrm{a}$ is a novel structural protein. Biochem. Biophys. Res. Commun. 2005, 330, 286-292.

[348] Siu, Y. L.; Teoh, K. T.; Lo, J.; Chan, C. M.; Kien, F.; Escriou, N.; Tsao, S. W.; Nicholls, J. M.; Altmeyer, R.; Peiris, J. S. M. et al. The $\mathrm{M}, \mathrm{E}$, and $\mathrm{N}$ structural proteins of the severe acute respiratory syndrome coronavirus are required for efficient assembly, trafficking, and release of virus-like particles. J. Virol. 2008, 82, 11318-11330.

[349] Zhao, P.; Ke, J. S.; Qin, Z. L.; Ren, H.; Zhao, L. J.; Yu, J. G.; Gao, J.; Zhu, S. Y.; Qi, Z. T. DNA vaccine of SARS-Cov S gene induces antibody response in mice. Acta Biochim. Biophys. Sin. 2004, 36, $37-41$.

[350] Wang, C. Y.; Li, W. T.; Drabek, D.; Okba, N. M. A.; van Haperen, R.; Osterhaus, A. D. M. E.; van Kuppeveld, F. J. M.; Haagmans, B. L.; Grosveld, F.; Bosch, B. J. A human monoclonal antibody blocking SARS-CoV-2 infection. Nat. Commun. 2020, 11, 2251.

[351] Cao, W. C.; Liu, W.; Zhang, P. H.; Zhang, F.; Richardus, J. H. Disappearance of antibodies to SARS-associated coronavirus after recovery. N. Engl. J. Med. 2007, 357, 1162-1163.

[352] Le Bert, N.; Tan, A. T.; Kunasegaran, K.; Tham, C. Y. L.; Hafezi, M.; Chia, A.; Chng, M. H. Y.; Lin, M. Y.; Tan, N.; Linster, M. et al. SARS-CoV-2-specific T cell immunity in cases of COVID-19 and SARS, and uninfected controls. Nature 2020, 584, 457-462.

[353] de Haan, C. A. M.; Kuo, L. L.; Masters, P. S.; Vennema, H.; Rottier, P. J. M. Coronavirus particle assembly: Primary structure requirements of the membrane protein. J. Virol. 1998, 72, $6838-6850$.

[354] DeDiego, M. L.; Álvarez, E.; Almazán, F.; Rejas, M. T.; Lamirande, E.; Roberts, A.; Shieh, W. J.; Zaki, S. R.; Subbarao, K.; Enjuanes, L. A severe acute respiratory syndrome coronavirus that lacks the e gene is attenuated in vitro and in vivo. J. Virol. 2007, 81, 1701-1713.

[355] Ortego, J.; Ceriani, J. E.; Patiño, C.; Plana, J.; Enjuanes, L. Absence of $\mathrm{E}$ protein arrests transmissible gastroenteritis coronavirus maturation in the secretory pathway. Virology 2007, 368, 296-308.

[356] Tissot, A. C.; Renhofa, R.; Schmitz, N.; Cielens, I.; Meijerink, E.; Ose, V.; Jennings, G. T.; Saudan, P.; Pumpens, P.; Bachmann, M. F. Versatile virus-like particle carrier for epitope based vaccines. PLoS One 2010, 5, e9809.

[357] Li, K. Y.; Peers-Adams, A.; Win, S. J.; Scullion, S.; Wilson, M.; Young, V. L.; Jennings, P.; Ward, V. K.; Baird, M. A.; Young, S. L. Antigen incorporated in virus-like particles is delivered to specific dendritic cell subsets that induce an effective antitumor immune response in vivo. J. Immunother. 2013, 36, 11-19.

[358] Ruedl, C.; Storni, T.; Lechner, F.; Bächi, T.; Bachmann, M. F. Cross-presentation of virus-like particles by skin-derived CD8dendritic cells: A dispensable role for TAP. Eur. J. Immunol. 2002, $32,818-825$.

[359] Liu, Y. V.; Massare, M. J.; Barnard, D. L.; Kort, T.; Nathan, M.; Wang, L.; Smith, G. Chimeric severe acute respiratory syndrome coronavirus (SARS-CoV) S glycoprotein and influenza matrix 1 efficiently form virus-like particles (VLPs) that protect mice against challenge with SARS-CoV. Vaccine 2011, 29, 6606-6613.

[360] Gillitzer, E.; Willits, D.; Young, M.; Douglas, T. Chemical modification of a viral cage for multivalent presentation. Chem. Commun. 2002, 21, 2390-2391.

[361] Smith, M. T.; Hawes, A. K.; Bundy, B. C. Reengineering viruses and virus-like particles through chemical functionalization strategies. Curr. Opin. Biotechnol. 2013, 24, 620-626.

[362] Thrane, S.; Janitzek, C. M.; Agerbæk, M. Ø.; Ditlev, S. B.;
Resende, M.; Nielsen, M. A.; Theander, T. G.; Salanti, A.; Sander, A. F. A novel virus-like particle based vaccine platform displaying the placental malaria antigen VAR2CSA. PLoS One 2015, 10, e0143071.

[363] Zakeri, B.; Fierer, J. O.; Celik, E.; Chittock, E. C.; Schwarz-Linek, U.; Moy, V. T.; Howarth, M. Peptide tag forming a rapid covalent bond to a protein, through engineering a bacterial adhesin. Proc. Natl. Acad. Sci. USA 2012, 109, E690-E697.

[364] Brune, K. D.; Leneghan, D. B.; Brian, I. J.; Ishizuka, A. S.; Bachmann, M. F.; Draper, S. J.; Biswas, S.; Howarth, M. Plug-anddisplay: Decoration of virus-like particles via isopeptide bonds for modular immunization. Sci. Rep. 2016, 6, 19234.

[365] Liu, Z. D.; Zhou, H.; Wang, W. J.; Tan, W. J.; Fu, Y. X.; Zhu, M. Z. A novel method for synthetic vaccine construction based on protein assembly. Sci. Rep. 2014, 4, 7266.

[366] Lee, C. D.; Yan, Y. P.; Liang, S. M.; Wang, T. F. Production of FMDV virus-like particles by a SUMO fusion protein approach in Escherichia coli. J. Biomed. Sci. 2009, 16, 69.

[367] Liew, M. W. O.; Rajendran, A.; Middelberg, A. P. J. Microbial production of virus-like particle vaccine protein at gram-per-litre levels. J. Biotechnol. 2010, 150, 224-231.

[368] Sasnauskas, K.; Buzaite, O.; Vogel, F.; Jandrig, B.; Razanskas, R.; Staniulis, J.; Scherneck, S.; Krüger, D. H.; Ulrich, R. Yeast cells allow high-level expression and formation of polyomavirus-like particles. Biol. Chem. 1999, 380, 381-386.

[369] Santi, L.; Batchelor, L.; Huang, Z.; Hjelm, B.; Kilbourne, J.; Arntzen, C. J.; Chen, Q.; Mason, H. S. An efficient plant viral expression system generating orally immunogenic Norwalk viruslike particles. Vaccine 2008, 26, 1846-1854.

[370] Santi, L.; Huang, Z.; Mason, H. Virus-like particles production in green plants. Methods 2006, 40, 66-76.

[371] Maranga, L.; Cruz, P. E.; Aunins, J. G.; Carrondo, M. J. Production of core and virus-like particles with baculovirus infected insect cells. Adv. Biochem. Eng. Biotechnol. 2002, 74, 183-206.

[372] Hsieh, P. K.; Chang, S. C.; Huang, C. C.; Lee, T. T.; Hsiao, C. W.; Kou, Y. H.; Chen, I. Y.; Chang, C. K.; Huang, T. H.; Chang, M. F. Assembly of severe acute respiratory syndrome coronavirus RNA packaging signal into virus-like particles is nucleocapsid dependent. J. Virol. 2005, 79, 13848-13855.

[373] Kost, T. A.; Condreay, J. P. Recombinant baculoviruses as mammalian cell gene-delivery vectors. Trends Biotechnol. 2002, 20, 173-180.

[374] Bundy, B. C.; Franciszkowicz, M. J.; Swartz, J. R. Escherichia colibased cell-free synthesis of virus-like particles. Biotechnol. Bioeng. 2008, 100, 28-37.

[375] Shi, X. Z.; Jarvis, D. L. Protein N-glycosylation in the baculovirusinsect cell system. Curr. Drug Targets 2007, 8, 1116-1125.

[376] Watanabe, Y.; Allen, J. D.; Wrapp, D.; McLellan, J. S.; Crispin, M. Site-specific glycan analysis of the SARS-CoV-2 spike. Science 2020, 369, 330-333.

[377] Margine, I.; Martinez-Gil, L.; Chou, Y. Y.; Krammer, F. Residual baculovirus in insect cell-derived influenza virus-like particle preparations enhances immunogenicity. PLoS One 2012, 7, e51559.

[378] Khan, K. H. Gene expression in Mammalian cells and its applications. Adv. Pharm. Bull. 2013, 3, 257-263.

[379] Chen, Q.; Lai, H. F. Plant-derived virus-like particles as vaccines Hum. Vaccin. Immunother. 2013, 9, 26-49.

[380] Kim, H. S.; Jeon, J. H.; Lee, K. J.; Ko, K. N-Glycosylation modification of plant-derived virus-like particles: An application in vaccines. BioMed Res. Int. 2014, 2014, 249519.

[381] Roldão, A.; Mellado, M. C. M.; Castilho, L. R.; Carrondo, M. J.; Alves, P. M. Virus-like particles in vaccine development. Expert Rev. Vaccines 2010, 9, 1149-1176.

[382] Hiatt, A.; Caffferkey, R.; Bowdish, K. Production of antibodies in transgenic plants. Nature 1989, 342, 76-78.

[383] Goodin, M. M.; Zaitlin, D.; Naidu, R. A.; Lommel, S. A. Nicotiana benthamiana: Its history and future as a model for plant-pathogen interactions. Mol. Plant Microbe Interact. 2008, 21, 1015-1026.

[384] Mason, H. S.; Lam, D. M.; Arntzen, C. J. Expression of hepatitis B surface antigen in transgenic plants. Proc. Natl. Acad. Sci. USA 1992, 89, 11745-11749. 
[385] Lacasse, P.; Denis, J.; Lapointe, R.; Leclerc, D.; Lamarre, A. Novel plant virus-based vaccine induces protective cytotoxic Tlymphocyte-mediated antiviral immunity through dendritic cell maturation. J. Virol. 2008, 82, 785-794.

[386] Pillet, S.; Aubin, É.; Trépanier, S.; Bussière, D.; Dargis, M.; Poulin, J. F.; Yassine-Diab, B.; Ward, B. J.; Landry, N. A plant-derived quadrivalent virus like particle influenza vaccine induces crossreactive antibody and $\mathrm{T}$ cell response in healthy adults. Clin. Immunol. 2016, 168, 72-87.

[387] Shriver, L. P.; Plummer, E. M.; Thomas, D. M.; Ho, S.; Manchester, M. Localization of gadolinium-loaded CPMV to sites of inflammation during central nervous system autoimmunity. $J$. Mater. Chem. B 2013, 1, 5256-5263.

[388] D'Aoust, M. A.; Lavoie, P. O.; Couture, M. M. J.; Trépanier, S.; Guay, J. M.; Dargis, M.; Mongrand, S.; Landry, N.; Ward, B. J.; Vézina, L. P. Influenza virus-like particles produced by transient expression in Nicotiana benthamiana induce a protective immune response against a lethal viral challenge in mice. Plant Biotechnol. J. 2008, 6, 930-940.

[389] Lindsay, B. J.; Bonar, M. M.; Costas-Cancelas, I. N.; Hunt, K.; Makarkov, A. I.; Chierzi, S.; Krawczyk, C. M.; Landry, N.; Ward, B. J.; Rouiller, I. Morphological characterization of a plant-made virus-like particle vaccine bearing influenza virus hemagglutinins by electron microscopy. Vaccine 2018, 36, 2147-2154.

[390] Gelvin, S. B. Agrobacterium-mediated plant transformation: The biology behind the "gene-jockeying" tool. Microbiol. Mol. Biol. Rev. 2003, 67, 16-37.

[391] Zupan, J. R.; Zambryski, P. Transfer of T-DNA from Agrobacterium to the plant cell. Plant Physiol. 1995, 107, 1041-1047.

[392] Morein, B.; Simons, K. Subunit vaccines against enveloped viruses: Virosomes, micelles and other protein complexes. Vaccine 1985, 3, 83-93.

[393] Hansson, M.; Nygren, P. Å.; Ståhl, S. Design and production of recombinant subunit vaccines. Biotechnol. Appl. Biochem. 2000, $32,95-107$.

[394] Donaldson, B.; Al-Barwani, F.; Young, V.; Scullion, S.; Ward, V.; Young, S. Virus-like particles, a versatile subunit vaccine platform. In Subunit Vaccine Delivery. Foged, C.; Rades, T.; Perrie, Y.; Hook, S., Eds.; Springer: New York, 2015; pp 159-180.

[395] Schiller, J. T.; Lowy, D. R. Raising expectations for subunit vaccine. J. Infect. Dis. 2015, 211, 1373-1375.

[396] Trimaille, T.; Lacroix, C.; Verrier, B. Self-assembled amphiphilic copolymers as dual delivery system for immunotherapy. Eur. J. Pharm. Biopharm. 2019, 142, 232-239.

[397] Trimaille, T.; Verrier, B. Micelle-based adjuvants for subunit vaccine delivery. Vaccines 2015, 3, 803-813.

[398] Zaman, M.; Skwarczynski, M.; Malcolm, J. M.; Urbani, C. N.; Jia, Z. F.; Batzloff, M. R.; Good, M. F.; Monteiro, M. J.; Toth, I. Selfadjuvanting polyacrylic nanoparticulate delivery system for group A streptococcus (GAS) vaccine. Nanomedicine Nanotechnol. Biol. Med. 2011, 7, 168-173.

[399] Silva, A. L.; Soema, P. C.; Slütter, B.; Ossendorp, F.; Jiskoot, W. PLGA particulate delivery systems for subunit vaccines: Linking particle properties to immunogenicity. Hum. Vaccin. Immunother. 2016, 12, 1056-1069.

[400] Radošević, K.; Rodriguez, A.; Mintardjo, R.; Tax, D.; Bengtsson, K. L.; Thompson, C.; Zambon, M.; Weverling, G. J.; UytdeHaag, F.; Goudsmit, J. Antibody and T-cell responses to a virosomal adjuvanted H9N2 avian influenza vaccine: Impact of distinct additional adjuvants. Vaccine 2008, 26, 3640-3646.

[401] Reimer, J. M.; Karlsson, K. H.; Lövgren-Bengtsson, K.; Magnusson, S. E.; Fuentes, A.; Stertman, L. Matrix-M ${ }^{\mathrm{TM}}$ adjuvant induces local recruitment, activation and maturation of central immune cells in absence of antigen. PLoS One 2012, 7, e41451.

[402] Shinde, V.; Fries, L.; Wu, Y. K.; Agrawal, S.; Cho, I.; Thomas, D. N.; Spindler, M.; Lindner, E.; Hahn, T.; Plested, J. et al. Improved titers against influenza drift variants with a nanoparticle vaccine. $N$. Engl. J. Med. 2018, 378, 2346-2348.

[403] Madhun, A. S.; Haaheim, L. R.; Nilsen, M. V.; Cox, R. J.
Intramuscular Matrix-M-adjuvanted virosomal $\mathrm{H} 5 \mathrm{~N} 1$ vaccine induces high frequencies of multifunctional $\mathrm{Th} 1 \mathrm{CD} 4^{+}$cells and strong antibody responses in mice. Vaccine 2009, 27, 7367-7376.

[404] Shinde, V.; Bhikha, S.; Hoosain, Z.; Archary, M.; Bhorat, Q.; Fairlie, L.; Lalloo, U.; Masilela, M. S. L.; Moodley, D.; Hanley, S. et al. Efficacy of NVX-CoV2373 Covid-19 vaccine against the B 1.351 variant. N. Engl. J. Med. 2021, 384, 1899-1909.

[405] Honda-Okubo, Y.; Barnard, D.; Ong, C. H.; Peng, B. H.; Tseng, C. T. K.; Petrovsky, N. Severe acute respiratory syndrome-associated coronavirus vaccines formulated with delta inulin adjuvants provide enhanced protection while ameliorating lung eosinophilic immunopathology. J. Virol. 2015, 89, 2995-3007.

[406] McPherson, C.; Chubet, R.; Holtz, K.; Honda-Okubo, Y.; Barnard, D.; Cox, M.; Petrovsky, N. Development of a SARS coronavirus vaccine from recombinant spike protein plus delta inulin adjuvant. Methods Mol. Biol. 2016, 1403, 269-284.

[407] Zhou, Z. M.; Post, P.; Chubet, R.; Holtz, K.; McPherson, C.; Petric, M.; Cox, M. A recombinant baculovirus-expressed S glycoprotein vaccine elicits high titers of SARS-associated coronavirus (SARS$\mathrm{CoV})$ neutralizing antibodies in mice. Vaccine 2006, 24, $3624-3631$.

[408] Kerekes, K.; Cooper, P. D.; Prechl, J.; Józsi, M.; Bajtay, Z.; Erdei, A. Adjuvant effect of $\gamma$-inulin is mediated by $\mathrm{C} 3$ fragments deposited on antigen-presenting cells. J. Leukoc. Biol. 2001, 69, 69-74.

[409] Müller-Eberhard, H. J. Molecular organization and function of the complement system. Annu. Rev. Biochem. 1988, 57, 321-347.

[410] Mai-Prochnow, A.; Hui, J. G. K.; Kjelleberg, S.; Rakonjac, J.; McDougald, D.; Rice, S. A. 'Big things in small packages: The genetics of filamentous phage and effects on fitness of their host' FEMS Microbiol. Rev. 2015, 39, 465-487.

[411] Hajitou, A.; Rangel, R.; Trepel, M.; Soghomonyan, S.; Gelovani, J. G.; Alauddin, M. M.; Pasqualini, R.; Arap, W. Design and construction of targeted AAVP vectors for mammalian cell transduction. Nat. Protoc. 2007, 2, 523-531.

[412] Namdee, K.; Khongkow, M.; Boonrungsiman, S.; Nittayasut, N.; Asavarut, P.; Temisak, S.; Saengkrit, N.; Puttipipatkhachorn, S.; Hajitou, A.; Ruxrungtham, K. et al. Thermoresponsive bacteriophage nanocarrier as a gene delivery vector targeted to the gastrointestinal Tract. Mol. Ther. Nucleic Acids 2018, 12, 33-44.

[413] Goracci, M.; Pignochino, Y.; Marchiò, S. Phage display-based nanotechnology applications in cancer immunotherapy. Molecules 2020, 25, 843 .

[414] Parmiani, G.; Russo, V.; Maccalli, C.; Parolini, D.; Rizzo, N.; Maio, M. Peptide-based vaccines for cancer therapy. Hum. Vaccin. Immunother. 2014, 10, 3175-3178.

[415] Coley, A. M.; Campanale, N. V.; Casey, J. L.; Hodder, A. N.; Crewther, P. E.; Anders, R. F.; Tilley, L. M.; Foley, M. Rapid and precise epitope mapping of monoclonal antibodies against Plasmodium falciparum AMA1 by combined phage display of fragments and random peptides. Protein Eng. Des. Sel. 2001, 14, 691-698.

[416] Lozano, J. M.; Bermúdez, A.; Patarroyo, M. E. Peptide vaccines for malaria. In Handbook of Biologically Active Peptides. Kastin, A. J., Ed.; Academic Press: Burlington, 2006; pp 515-526.

[417] Frenkel, D.; Katz, O.; Solomon, B. Immunization against Alzheimer's $\beta$-amyloid plaques via EFRH phage administration. Proc. Natl. Acad. Sci. USA 2000, 97, 11455-11459.

[418] Umscheid, C. A.; Margolis, D. J.; Grossman, C. E. Key concepts of clinical trials: A narrative review. Postgrad. Med. 2011, 123, 194-204.

[419] Bao, L. L.; Deng, W.; Huang, B. Y.; Gao, H.; Liu, J. N.; Ren, L. L.; Wei, Q.; Yu, P.; Xu, Y. F.; Qi, F. F. et al. The pathogenicity of SARS-CoV-2 in hACE2 transgenic mice. Nature 2020, 583, 830-833.

[420] Gu, H. J.; Chen, Q.; Yang, G.; He, L.; Fan, H.; Deng, Y. Q.; Wang, Y. X.; Teng, Y.; Zhao, Z. P.; Cui, Y. J. et al. Adaptation of SARS$\mathrm{CoV}-2$ in BALB/c mice for testing vaccine efficacy. Science $\mathbf{2 0 2 0}$, $369,1603-1607$.

[421] Chan, J. F. W.; Zhang, A. J.; Yuan, S. F.; Poon, V. K. M.; Chan, C. 
C. S.; Lee, A. C. Y.; Chan, W. M.; Fan, Z. M.; Tsoi, H. W.; Wen, L. et al. Simulation of the clinical and pathological manifestations of Coronavirus Disease 2019 (COVID-19) in a golden Syrian hamster model: Implications for disease pathogenesis and transmissibility. Clin. Infect. Dis. 2020, 71, 2428-2446.

[422] Kim, Y. I.; Kim, S. G.; Kim, S. M.; Kim, E. H.; Park, S. J.; Yu, K. M.; Chang, J. H.; Kim, E. J.; Lee, S.; Casel, M. A. B. et al. Infection and rapid transmission of SARS-CoV-2 in ferrets. Cell Host Microbe 2020, 27, 704-709.e2.

[423] Richard, M.; Kok, A.; de Meulder, D.; Bestebroer, T. M.; Lamers, M. M.; Okba, N. M. A.; van Vlissingen, M. F.; Rockx, B.; Haagmans, B. L.; Koopmans, M. P. G. et al. SARS-CoV-2 is transmitted via contact and via the air between ferrets. Nat. Commun. 2020, 11, 3496.

[424] Chandrashekar, A.; Liu, J. Y.; Martinot, A. J.; McMahan, K.; Mercado, N. B.; Peter, L.; Tostanoski, L. H.; Yu, J. Y.; Maliga, Z.; Nekorchuk, M. et al. SARS-CoV-2 infection protects against rechallenge in rhesus macaques. Science 2020, 369, 812-817.

[425] Ursino, M.; Zohar, S.; Lentz, F.; Alberti, C.; Friede, T.; Stallard, N.; Comets, E. Dose-finding methods for Phase I clinical trials using pharmacokinetics in small populations. Biom. J. 2017, 59, 804-825.

[426] Roth, R. I. Human clinical safety assessment procedures. In Comprehensive Toxicology. McQueen, C. A., Ed.; Elsevier: Amsterdam, 2010; pp 173-181.

[427] Buyse, M. Phase III design: Principles. Chin. Clin. Oncol. 2016, 5, 10.

[428] Rai, S. N.; Qian, C.; Pan, J. M.; Seth, A.; Srivastava, D. K.; Bhatnagar, A. Statistical design of Phase II/III clinical trials for testing therapeutic interventions in COVID-19 patients. BMC Med. Res. Methodol. 2020, 20, 220.

[429] Hodgson, S. H.; Mansatta, K.; Mallett, G.; Harris, V.; Emary, K. R. W.; Pollard, A. J. What defines an efficacious COVID-19 vaccine? A review of the challenges assessing the clinical efficacy of vaccines against SARS-CoV-2. Lancet Infect. Dis. 2021, 21, E26-E35.

[430] Tregoning, J. S.; Flight, K. E.; Higham, S. L.; Wang, Z. Y.; Pierce, B. F. Progress of the COVID-19 vaccine effort: Viruses, vaccines and variants versus efficacy, effectiveness and escape. Nat. Rev. Immunol. 2021, DOI: 10.1038/s41577-021-00592-1.

[431] Werbel, W. A.; Boyarsky, B. J.; Ou, M. T.; Massie, A. B.; Tobian, A. A. R.; Garonzik-Wang, J. M.; Segev, D. L. Safety and immunogenicity of a third dose of SARS-CoV-2 vaccine in solid organ transplant recipients: A case series. Ann. Intern. Med. 2021, L21-0282.

[432] 't Hart, B. A.; Bogers, W. M.; Haanstra, K. G.; Verreck, F. A.; Kocken, C. H. The translational value of non-human primates in preclinical research on infection and immunopathology. Eur. J. Pharmacol. 2015, 759, 69-83.

[433] Johansen, M. D.; Irving, A.; Montagutelli, X.; Tate, M. D.; Rudloff, T. I.; Nold, M. F.; Hansbro, N. G.; Kim, R. Y.; Donovan, C.; Liu, G. et al. Animal and translational models of SARS-CoV-2 infection and COVID-19. Mucosal Immunol. 2020, 13, 877-891.

[434] Muñoz-Fontela, C.; Dowling, W. E.; Funnell, S. G. P.; Gsell, P. S.; Riveros-Balta, A. X.; Albrecht, R. A.; Andersen, H.; Baric, R. S.;
Carroll, M. W.; Cavaleri, M. et al. Animal models for COVID-19. Nature 2020, 586, 509-515.

[435] Dearlove, B.; Lewitus, E.; Bai, H. J.; Li, Y. F.; Reeves, D. B.; Joyce, M. G.; Scott, P. T.; Amare, M. F.; Vasan, S.; Michael, N. L. et al. A SARS-CoV-2 vaccine candidate would likely match all currently circulating variants. Proc. Natl. Acad. Sci. USA 2020, 117, 23652-23662.

[436] Koyama, T.; Platt, D.; Parida, L. Variant analysis of SARS-CoV-2 genomes. Bull. World Health Organ. 2020, 98, 495-504.

[437] Kis, Z.; Kontoravdi, C.; Dey, A. K.; Shattock, R.; Shah, N. Rapid development and deployment of high-volume vaccines for pandemic response. J. Adv. Manuf. Process. 2020, 2, e10060.

[438] Bahamondez-Canas, T. F.; Cui, Z. R. Intranasal immunization with dry powder vaccines. Eur. J. Pharm. Biopharm. 2018, 122, 167-175.

[439] Pissuwan, D.; Nose, K.; Kurihara, R.; Kaneko, K.; Tahara, Y.; Kamiya, N.; Goto, M.; Katayama, Y.; Niidome, T. A solid-in-oil dispersion of gold nanorods can enhance transdermal protein delivery and skin vaccination. Small 2011, 7, 215-220.

[440] Perlman, S.; Netland, J. Coronaviruses post-SARS: Update on replication and pathogenesis. Nat. Rev. Microbiol. 2009, 7, 439-450.

[441] McGrath, B. A.; Brenner, M. J.; Warrillow, S. J.; Pandian, V.; Arora, A.; Cameron, T. S.; Añon, J. M.; Hernández Martínez, G.; Truog, R. D.; Block, S. D. et al. Tracheostomy in the COVID-19 era: Global and multidisciplinary guidance. Lancet Respir. Med. 2020, 8, 717-725.

[442] Apostolopoulos, V.; Thalhammer, T.; Tzakos, A. G.; Stojanovska, L. Targeting antigens to dendritic cell receptors for vaccine development. J. Drug Deliv. 2013, 2013, 869718.

[443] Xia, S. L.; Duan, K.; Zhang, Y. T.; Zhao, D. Y.; Zhang, H. J.; Xie, Z. Q.; Li, X. G.; Peng, C.; Zhang, Y. B.; Zhang, W. et al. Effect of an inactivated vaccine against SARS-CoV-2 on safety and immunogenicity outcomes: Interim analysis of 2 randomized clinical trials. JAMA 2020, 324, 951-960.

[444] Isakova-Sivak, I.; Rudenko, L. A promising inactivated wholevirion SARS-CoV-2 vaccine. Lancet Infect. Dis. 2021, 21, 2-3.

[445] Mohandas, S.; Yadav, P. D.; Shete, A.; Abraham, P.; Mohan, K.; Sapkal, G.; Mote, C.; Nyayanit, D.; Gupta, N.; Srini, V. K. et al. Immunogenicity and protective efficacy of BBV152: A whole virion inactivated SARS CoV-2 vaccine in the Syrian hamster model, 2020.

[446] Logunov, D. Y.; Dolzhikova, I. V.; Zubkova, O. V.; Tukhvatulin, A. I.; Shcheblyakov, D. V.; Dzharullaeva, A. S.; Grousova, D. M.; Erokhova, A. S.; Kovyrshina, A. V.; Botikov, A. G. et al. Safety and immunogenicity of an rAd26 and rAd5 vector-based heterologous prime-boost COVID-19 vaccine in two formulations: Two open, non-randomised phase $1 / 2$ studies from Russia. Lancet 2020, 396, 887-897.

[447] Folegatti, P. M.; Ewer, K. J.; Aley, P. K.; Angus, B.; Becker, S.; Belij-Rammerstorfer, S.; Bellamy, D.; Bibi, S.; Bittaye, M.; Clutterbuck, E. A. et al. Safety and immunogenicity of the ChAdOx1 nCoV-19 vaccine against SARS-CoV-2: A preliminary report of a phase $1 / 2$, single-blind, randomised controlled trial. Lancet 2020, 396, 467-478. 